\title{
Central Facilities Area Facilities Radioactive Waste Management Basis and DOE Manual 435.1-1 Compliance Tables
}

November 2011

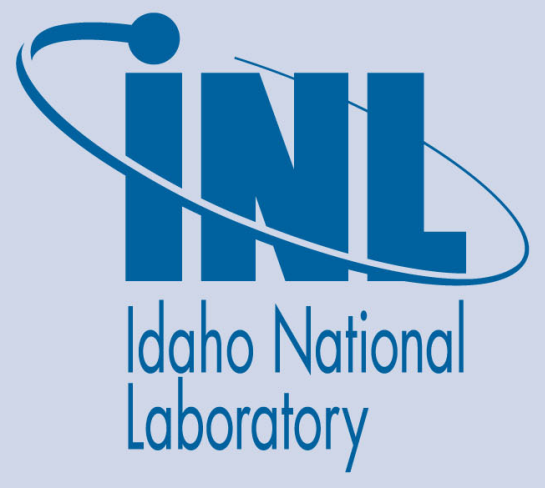

The INL is a U.S. Department of Energy National Laboratory operated by Battelle Energy Alliance 


\section{DISCLAIMER}

This information was prepared as an account of work sponsored by an agency of the U.S. Government. Neither the U.S. Government nor any agency thereof, nor any of their employees, makes any warranty, expressed or implied, or assumes any legal liability or responsibility for the accuracy, completeness, or usefulness, of any information, apparatus, product, or process disclosed, or represents that its use would not infringe privately owned rights. References herein to any specific commercial product, process, or service by trade name, trade mark, manufacturer, or otherwise, does not necessarily constitute or imply its endorsement, recommendation, or favoring by the U.S. Government or any agency thereof. The views and opinions of authors expressed herein do not necessarily state or reflect those of the U.S. Government or any agency thereof. 
INL/EXT-10-19790

Revision 2

\section{Central Facilities Area Facilities Radioactive Waste Management Basis and DOE Manual 435.1-1 Compliance Tables}

November 2011

Idaho National Laboratory Idaho Falls, Idaho 83415

http://www.inl.gov

Prepared for the

U.S. Department of Energy

Office of Nuclear Energy

Under DOE Idaho Operations Office

Contract DE-AC07-05ID14517 



\begin{abstract}
Department of Energy Order 435.1, "Radioactive Waste Management," along with its associated manual and guidance, requires development and maintenance of a radioactive waste management basis for each radioactive waste management facility, operation, and activity. This document presents a radioactive waste management basis for Idaho National Laboratory's Central Facilities Area facilities that manage radioactive waste. The radioactive waste management basis for a facility comprises existing laboratory-wide and facilityspecific documents. Department of Energy Manual 435.1-1, "Radioactive Waste Management Manual," facility compliance tables also are presented for the facilities. The tables serve as a tool for developing the radioactive waste management basis.
\end{abstract}




\section{CONTENTS}

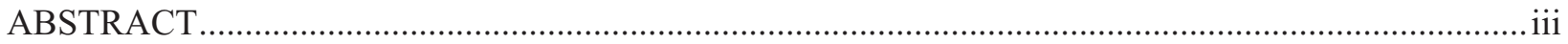

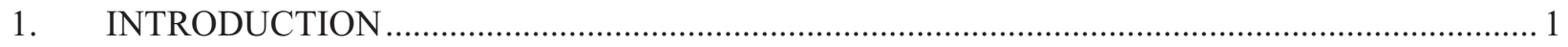

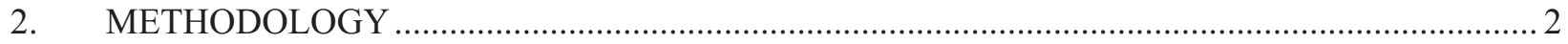

3. SCOPE

4. FACILITY RADIOACTIVE WASTE MANAGEMENT BASIS AND DOE MANUAL

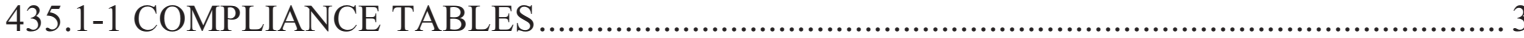

4.1 CFA-622, High-Temperature Materials Laboratory …....................................................... 3

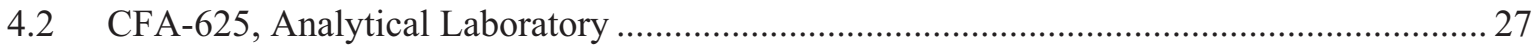

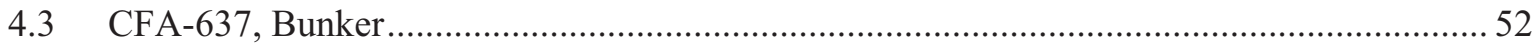

4.4 CFA-690, Radiological and Environmental Sciences Laboratory ...................................... 75

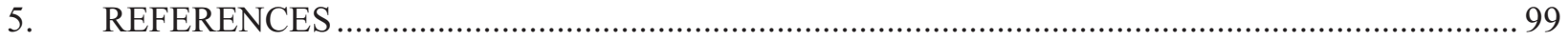

\section{TABLES}

1. CFA-622, High-Temperature Materials Laboratory, DOE Manual 435.1-1 low-level waste requirements and facility compliance information .................................................... 5

2. CFA-625, Analytical Laboratory, DOE Manual 435.1-1 low-level waste requirements

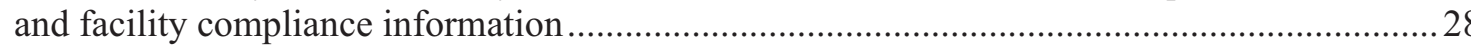

3. CFA-637, Bunker, DOE Manual 435.1-1 low-level waste requirements and facility compliance information

4. CFA-690, Radiological and Environmental Sciences Laboratory, DOE Manual 435.1-1 low-level waste requirements and facility compliance information 


\section{Central Facilities Area Facilities Radioactive Waste Management Basis and DOE Manual 435.1-1 Compliance Tables}

\section{INTRODUCTION}

The U.S. Department of Energy (DOE) ensures that DOE radioactive waste is managed in a manner that is protective of worker and public health and the environment through DOE Order 435.1, "Radioactive Waste Management," and its associated manual (DOE Manual 435.1-1, "Radioactive Waste Management Manual") and guidance (DOE Guide 435.1-1, "Implementation Guide for Use with DOE M 435.1-1"). As required by DOE Manual 435.1-1, I.F.(2), field element managers are responsible for ensuring that a radioactive waste management basis (RWMB) is developed and maintained for each DOE radioactive waste management facility, operation, and activity. The RWMB must do the following:

- Reference or define the conditions under which the facility may operate based on the radioactive waste management documentation

- Include the applicable elements indentified in the specific waste type chapters of the manual (DOE Manual 435.1-1)

- Be developed using the graded approach process.

The specific waste type chapters of DOE Manual 435.1-1 are high-level waste (Chapter II), transuranic (TRU) waste (Chapter III), and low-level waste (LLW) (Chapter IV). The RWMB is required to consist of "physical and administrative controls to ensure the protection of workers, the public, and the environment." For TRU waste and LLW, the RWMB is to include the following specific waste management controls:

- For generators, the waste certification program

- For treatment facilities and storage facilities, the waste acceptance requirements and the waste certification program

- For disposal facilities, the performance assessment, composite analysis, disposal authorization statement, closure plan, waste acceptance requirements, and monitoring plan.

Similar waste management controls are specified for high-level waste generators and high-level waste pretreatment, treatment, and storage facilities.

However, consistent with the graded approach provided in the DOE guidance, the required elements of the RWMB vary with the type of waste management operation or facility and the types of hazards associated with the facility. Therefore, the elements that are included in the guidance for each waste type chapter of the manual are not to be considered a complete list of elements. For example, the elements determined to be applicable to the RWMB for a facility may include the facility safety basis; authorization basis; operational procedures; radiation protection controls and procedures; waste characterization and certification plan; waste acceptance criteria; waste tracking and records management; waste storage and staging requirements; facility monitoring; quality assurance; and regulatory permits and appropriate documentation for permitted facilities.

The purpose of this document is to present a RWMB for the Central Facilities Area (CFA) facilities that manage radioactive waste and DOE Manual 435.1-1 facility compliance information tables for the CFA facilities. The facility RWMB comprises existing laboratory-wide and facility-specific documents. The DOE Manual 435.1-1 facility compliance information tables show how each facility meets the DOE Manual 435.1-1 requirement for a waste type and serve as a tool to develop the RWMB. The tables 
provide information that BEA and facility management officials can use to apply the graded approach emphasized in DOE Order 435.1 and its associated manual and guidance. This document is intended to support the summary RWMB (PLN-3653) for the facilities managing radioactive waste at the CFA. The summary RWMB is to be submitted to the DOE field element manager for approval.

\section{METHODOLOGY}

The following methodology was used to prepare preliminary RWMB and facility compliance information tables for the CFA facilities:

- A kick-off meeting was held with CFA officials. At this meeting, a preliminary list of CFA facilities that should be included in this effort was verified. Based on the information obtained at this meeting, the list of facilities was modified slightly. The CFA official also provided the point of contact (POC) for each facility that could provide facility radioactive waste management information.

- Interviews were conducted with the primary POCs to discuss radioactive waste management procedures and programs at each facility. The interviews were conducted between June 17, 2010, and July 28, 2010.

- Based on the information received from the interviews and analysis of the procedures cited by the facility POCs and found through the Electronic Document Management System, initial draft tables that describe facility-level compliance with DOE Manual 435.1-1 requirements for each facility and each waste type managed at the facility were developed.

- A review meeting with the facility POCs and BEA management officials, which was intended to serve as verification of the information presented in the initial draft tables, was cancelled. Subsequent attempts to re-schedule this meeting failed. The meeting also would have allowed BEA management officials to discuss and make decisions regarding the potential compliance issues unique to these facilities.

- The tables were revised based only on input received via follow-up interviews with the facility POCs that responded to the attempts to reach them.

- For each facility, a preliminary RWMB and a list of areas requiring further BEA and facility management actions were developed based on information from the revised tables.

In developing and reviewing the compliance information and preliminary RWMB, the graded approach that DOE specifies for developing the RWMB and that is emphasized throughout the DOE Guide 435.1-1 guidance was used. The guidance also states that, when possible, existing processes, programs, and documentation should be considered as possible ways to comply with DOE Manual 435.1-1 requirements (DOE Guide 435.1-1).

Both the manual and associated guidance were considered in developing and reviewing the preliminary RWMB. DOE Manual 435.1-1 describes the requirements and establishes specific responsibilities for implementing DOE Order 435.1 for the management of DOE high-level waste, TRU waste, LLW, and the radioactive component of mixed waste. DOE Guide 435.1-1 was developed to aid in implementing DOE Manual 435.1-1 requirements. The guide aids in understanding what is necessary to attain compliance, facilitates effective and efficient implementation of the requirements, and offers acceptable ways to implement the requirements. The guide is not meant to be viewed as additional or mandatory requirements. The guide emphasizes consideration of situation-specific attributes and application of the graded approach to dictate the rigor applied to implementation (DOE Guide 435.1-1 and DOE Manual 435.1-1). 


\section{SCOPE}

The following CFA facilities were identified as managing radioactive waste and are included in this study:

- CFA-622, High-Temperature Materials Laboratory

- CFA-625, Analytical Laboratory

- CFA-637, Bunker (Temporary Accumulation Area [TAA])

- CFA-690, Radiological and Environmental Sciences Laboratory (RESL).

\section{FACILITY RADIOACTIVE WASTE MANAGEMENT BASIS AND DOE MANUAL 435.1-1 COMPLIANCE TABLES}

This section presents the RWMB and DOE Manual 435.1-1 compliance tables for the following CFA facilities:

- CFA-622, High-Temperature Materials Laboratory (Subsection 4.1)

- CFA-625, Analytical Laboratory (Subsection 4.2)

- CFA-637, Bunker (TAA) (Subsection 4.3)

- CFA-690, RESL (Subsection 4.4).

For each CFA building housing these facilities, a brief facility overview is provided. The overview includes a facility description, the facility's safety basis classification, the radioactive waste management activities and waste types for the facility, a list of the RWMB documents and programs for the facility, and a list of the compliance requirements needing further BEA management action.

The DOE Manual 435.1-1 compliance information table for each radioactive waste type managed at each CFA facility also is provided for each facility. Each table shows the DOE Manual 435.1-1 requirement, facility compliance information for each requirement, and compliance issues for consideration by INL, BEA, and facility management, as appropriate. In some cases, excerpts from the DOE Guide 435.1-1 guidance associated with the DOE Manual 435.1-1 requirement are included. These excerpts are included to provide additional context and information about the requirement. However, the complete guidance citation should be consulted for decision-making.

\subsection{CFA-622, High-Temperature Materials Laboratory}

1. Facility Description: The High-Temperature Materials Laboratory (CFA-622) is a one-story building constructed on a steel frame with metal siding and a metal roof. The building sits on a concrete slab. The building provides approximately $10,500 \mathrm{ft}^{2}$ of floor space. The entire area of the building is protected by a wet pipe fire suppression system.

Activities conducted in the facility include fabrication and demonstration of the performance of nuclear reactor components and instrumentation, as well as evaluation of the performance of components or materials to be used in nuclear reactors. Evaluations are typically conducted using specialized fixtures in which prototypic materials, components, or sensors are tested under prototypic pressures and temperatures. Such tests are typically conducted in commercially-procured furnaces or an autoclave. Another type of testing is done with commercially available systems designed to obtain material properties (e.g., thermal diffusivity, thermal expansion, and specific heat capacity).

In some tests, components (about $0.1 \times 0.1 \times 1.0$ in.) previously irradiated in test reactor capsules are heated in a furnace placed inside an $8 \times 8 \times 8$-ft Perma-Con, stainless steel enclosure that sits in a 
stainless steel floor pan. The enclosure consists of several wall panels, a door containing a louvered vent, and several window panels. Gaseous releases from this furnace are vented through a small ventilation system and exhausted to a high-efficiency particulate air filter outside the building. A constant air monitor monitors the ventilation system. The constant air monitor is operated only during those tests or experiments where the test mixture contains radioactive material. Air flow through the enclosure is such that the maximum temperature of the air in the enclosure during an experiment will be $39^{\circ} \mathrm{C}\left(70^{\circ} \mathrm{F}\right)$ above the inlet air temperature. The maximum temperature of the enclosure walls is expected to remain at ambient temperature. The building has floor drains that are radiologically clean. All experiments with radioactive materials are performed inside the Perma-Con enclosure.

2. Hazard category: Less-than-Hazard-Category-3 (LTHC3) radiological.

3. Radioactive waste managed at this facility: Routine contact-handled LLW and mixed LLW are generated and staged in this facility.

4. RWMB documents/programs:

a) Safety basis/hazard analysis:

- ECAR-763, "Hazard Categorization of the High Temperature Test Laboratory CFA-622"

b) Laboratory-wide:

- Form 435.39, "Waste Determination and Disposition Form (WDDF)"

- Form 435.42, "Radioactive Waste Inventory Sheet"

- Form 441.A34, "INL Radiological Control Required Surveys"

- LI-435, "Waste Management Routine Field Activities"

- LRD-15001, "Radiological Control Manual"

- LWP-8000, "Environmental Instructions for Facilities, Processes, Materials and Equipment"

- LWP-13840, "Management of Issues, Observations, and Noteworthy Practices"

- LWP-14002, "Timeout and Stop Work Authority"

- LWP-15011, "Radioactive Material Areas and Radioactive Storage Areas"

- LWP-17000, "Waste Management"

- MCP-139, "Radiological Surveys"

- MCP-17000, "Waste Generator Services Waste Management"

- MCP-17410, "Management of Waste Storage Areas"

- MCP-17500, "Waste Generator Services Certification of Waste Shipments to the Nevada Test Site"

- PDD-17000, "Waste Management Program"

- PLN-114, "INL Emergency Plan/RCRA Contingency Plan"

- PLN-522, "Quality Assurance Program Plan for the Waste Management/Waste Certification Program"

c) Facility-specific:

- 1529-09-CFA, "Silicon Carbide Temperature Monitors."

LLW is managed at this facility. Table 1 presents the facility compliance information for Chapter IV, "Low-level Waste Requirements." 
Table 1. CFA-622, High-Temperature Materials Laboratory, DOE Manual 435.1-1 low-level waste requirements and facility compliance information.

\begin{tabular}{|c|c|}
\hline \multicolumn{2}{|c|}{ Facility Name: CFA-622 High-Temperature Materials Laboratory } \\
\hline Chapter IV, LLW Requirements & Facility Compliance Information \\
\hline $\begin{array}{l}\text { A. Definition of Low-Level Waste. Low-level radioactive } \\
\text { waste is radioactive waste that is not high-level } \\
\text { radioactive waste, spent nuclear fuel, transuranic waste, } \\
\text { byproduct material (as defined in section 11e.(2) of the } \\
\text { Atomic Energy Act of 1954, as amended), or naturally } \\
\text { occurring radioactive material. } \\
\text { (From DOE G } 435.1-1 \text { Chapter IV: Low-level radioactive } \\
\text { waste is defined by what it is not. The guidance on } \\
\text { definitions in Chapters II and III should be consulted first } \\
\text { for making a determination on how to properly manage a } \\
\text { suspect waste stream.) }\end{array}$ & $\begin{array}{l}\text { This requirement provides the criteria for determining } \\
\text { which DOE radioactive waste is to be managed as LLW } \\
\text { in accordance with DOE Manual } 435.1-1 \text {, Chapter IV. } \\
\text { Radioactive waste managed at this facility under the } \\
\text { requirements of this chapter is not managed under the } \\
\text { requirements of DOE Manual } 435.1-1 \text {, Chapter II or } \\
\text { Chapter III. }\end{array}$ \\
\hline $\begin{array}{l}\text { B. Management of Specific Wastes. The following } \\
\text { provide for management of specific wastes as low-level } \\
\text { waste in accordance with the requirements in this } \\
\text { Chapter: }\end{array}$ & See (1), (2), (3), and (4) below. \\
\hline $\begin{array}{l}\text { (1) Mixed Low-Level Waste. Low-level waste determined } \\
\text { to contain both source, special nuclear, or byproduct } \\
\text { material subject to the Atomic Energy Act of } 1954 \text {, as } \\
\text { amended, and a hazardous component subject to the } \\
\text { Resource Conservation and Recovery Act (RCRA), as } \\
\text { amended, shall be managed in accordance with the } \\
\text { requirements of RCRA and DOE O 435.1, Radioactive } \\
\text { Waste Management, and this Manual. }\end{array}$ & $\begin{array}{l}\text { This facility manages mixed LLW in satellite } \\
\text { accumulation areas (SAAs). Management of SAAs is } \\
\text { addressed in MCP-17410 and overall management of } \\
\text { mixed waste is addressed in MCP-17000. }\end{array}$ \\
\hline $\begin{array}{l}\text { (2) TSCA-Regulated Waste. Low-level waste containing } \\
\text { polychlorinated biphenyls, asbestos, or other such } \\
\text { regulated toxic components shall be managed in } \\
\text { accordance with requirements derived from the Toxic } \\
\text { Substances Control Act, as amended, DOE O 435.1, } \\
\text { Radioactive Waste Management, and this Manual. }\end{array}$ & $\begin{array}{l}\text { Not applicable (NA). This facility does not manage } \\
\text { TSCA-regulated waste. }\end{array}$ \\
\hline $\begin{array}{l}\text { (3) Accelerator-Produced Waste. Radioactive waste } \\
\text { produced as a result of operations of DOE accelerators is } \\
\text { low-level waste and shall be managed in accordance with } \\
\text { DOE O 435.1, Radioactive Waste Management, and this } \\
\text { Manual, and all applicable Federal or State requirements. }\end{array}$ & $\begin{array}{l}\text { NA; this facility does not manage accelerator-produced } \\
\text { waste. }\end{array}$ \\
\hline $\begin{array}{l}\text { (4) } 11 \text { e.(2) and Naturally Occurring Radioactive Material. } \\
\text { Small quantities of } 11 \text { e.(2) byproduct material and } \\
\text { naturally occurring radioactive material may be managed } \\
\text { as low-level waste provided they can be managed to meet } \\
\text { the requirements for low-level waste disposal in Section } \\
\text { IV.P of this Manual. }\end{array}$ & $\begin{array}{l}\text { NA; this facility does not manage naturally occurring } \\
\text { radioactive material. }\end{array}$ \\
\hline $\begin{array}{l}\text { C. Complex-Wide Low-Level Waste Management } \\
\text { Program. A complex-wide program and plan shall be } \\
\text { developed as described under Responsibilities, } 2 . B \text { and } \\
\text { 2.D, in Chapter I of this Manual. }\end{array}$ & $\begin{array}{l}\text { Not a facility-specific requirement. DOE Manual } \\
435.1-1 \S I .2 . B \text { and } § I .2 . D \text { apply to the Assistant } \\
\text { Secretary for Environmental Management and the } \\
\text { Deputy Assistant Secretary for Waste Management, } \\
\text { respectively. }\end{array}$ \\
\hline
\end{tabular}


Table 1. (continued).

\begin{tabular}{|c|c|}
\hline \multicolumn{2}{|c|}{ Facility Name: CFA-622 High-Temperature Materials Laboratory } \\
\hline Chapter IV, LLW Requirements & Facility Compliance Information \\
\hline $\begin{array}{l}\text { D. Radioactive Waste Management Basis. Low-level } \\
\text { waste facilities, operations, and activities shall have a } \\
\text { radioactive waste management basis consisting of } \\
\text { physical and administrative controls to ensure the } \\
\text { protection of workers, the public, and the environment. } \\
\text { The following specific waste management controls shall } \\
\text { be part of the radioactive waste management basis: }\end{array}$ & $\begin{array}{l}\text { The RWMB provides the regulatory framework for } \\
\text { management of radioactive waste at INL. It specifically } \\
\text { identifies facility management and implementing } \\
\text { documents for the generation, storage, treatment, and } \\
\text { disposal of radiological waste. }\end{array}$ \\
\hline $\begin{array}{l}\text { (1) Generators. The waste certification program. } \\
\text { From DOE G } 435.1-1 \text { Chapter IV: For a facility that } \\
\text { generates low-level waste, the radioactive waste } \\
\text { management basis is to include the program for certifying } \\
\text { that waste meets the waste acceptance requirements of the } \\
\text { facility(ies) to which the waste will be sent. }\end{array}$ & $\begin{array}{l}\text { See J. below for waste certification program } \\
\text { requirements. } \\
\text { ECAR-763 establishes the laboratory facility as LTHC3 } \\
\text { facility. }\end{array}$ \\
\hline $\begin{array}{l}\text { (2) Treatment Facilities. certification program. The waste } \\
\text { acceptance requirements and the waste [sic] } \\
\text { From DOE G 435.1-1 Chapter IV: Facilities that store or } \\
\text { treat low-level waste are to have approved waste } \\
\text { acceptance requirements (see DOE M 435.1-1, Section } \\
\text { IV.G) prior to the issuance of a radioactive waste } \\
\text { management basis. } \\
\text { A facility that stores or treats waste also is generally } \\
\text { expected to have a waste certification program. Waste } \\
\text { from these facilities will have to be certified as meeting } \\
\text { the waste acceptance requirements of the facility to which } \\
\text { it will be transferred, and the facilities have the potential } \\
\text { for generating radioactive waste (e.g., secondary } \\
\text { processing streams from treatment, monitoring and } \\
\text { sampling, radioactive release cleanup). Consequently, } \\
\text { storage and treatment facilities should also have an } \\
\text { approved waste certification program as part of their } \\
\text { radioactive waste management basis. } \\
\text { As part of the radioactive waste management basis, site } \\
\text { personnel needs to implement a system or process for } \\
\text { tracking the waste inventory at a storage, treatment, or } \\
\text { disposal facility. }\end{array}$ & $\begin{array}{l}\text { NA; waste is not treated at this facility. } \\
\text { Containerized elementary neutralization is performed at } \\
\text { this facility as provided by LWP- } 8000 \text {. As stated in } \\
\$ 4.118 \text {, elementary neutralization of corrosive } \\
\text { hazardous waste may take place at any location at } \\
\text { which the waste is generated or stored, and neither a } \\
\text { generator treatment plan nor a permit is required. } \\
\text { Solidification of liquid LLW for the purpose of staging } \\
\text { (not for treating the radioactive constituents) also may } \\
\text { be performed. Therefore, this facility is not considered } \\
\text { to be a treatment facility. }\end{array}$ \\
\hline $\begin{array}{l}\text { (3) Storage Facilities. The waste acceptance requirements } \\
\text { and the waste certification program. } \\
\text { From DOE G 435.1-1 Chapter IV: Facilities that store or } \\
\text { treat low-level waste are to have approved waste } \\
\text { acceptance requirements (see DOE M 435.1-1, Section } \\
\text { IV.G) prior to the issuance of a radioactive waste } \\
\text { management basis. } \\
\text { A facility that stores or treats waste also is generally } \\
\text { expected to have a waste certification program. Waste } \\
\text { from these facilities will have to be certified as meeting } \\
\text { the waste acceptance requirements of the facility to which } \\
\text { it will be transferred, and the facilities have the potential }\end{array}$ & $\begin{array}{l}\text { NA; this facility stages waste in accordance with } \mathrm{N}(7) \\
\text { to facilitate treatment or disposal. }\end{array}$ \\
\hline
\end{tabular}


Table 1. (continued).

Facility Name: CFA-622 High-Temperature Materials Laboratory

\begin{tabular}{|c|}
\hline Chapter IV, LLW Requirements \\
\hline $\begin{array}{l}\text { for generating radioactive waste (e.g., secondary } \\
\text { processing streams from treatment, monitoring and } \\
\text { sampling, radioactive release cleanup). Consequently, } \\
\text { storage and treatment facilities should also have an } \\
\text { approved waste certification program as part of their } \\
\text { radioactive waste management basis. }\end{array}$ \\
\hline $\begin{array}{l}\text { As part of the radioactive waste management basis, site } \\
\text { personnel needs to implement a system or process for } \\
\text { tracking the waste inventory at a storage, treatment, or } \\
\text { disposal facility. }\end{array}$ \\
\hline $\begin{array}{l}\text { (4) Disposal Facilities. The performance assessment, } \\
\text { composite analysis, disposal authorization statement, } \\
\text { closure plan, waste acceptance requirements, and } \\
\text { monitoring plan. }\end{array}$ \\
\hline $\begin{array}{l}\text { E. Contingency Actions. The following requirements are } \\
\text { in addition to those in Chapter I of this Manual [DOE M } \\
\text { 435.1-1 §I.1.E(5)]. }\end{array}$ \\
\hline
\end{tabular}

(1) Contingency Storage. For off-normal or emergency situations involving high activity or high hazard liquid low-level waste storage or treatment, spare capacity with adequate capabilities shall be maintained to receive the largest volume of liquid contained in any one storage tank or treatment facility. Tanks or other facilities that are designated low-level waste contingency storage shall be maintained in an operational condition when waste is present and shall meet the requirements of DOE O 435.1, Radioactive Waste Management, and this Manual.

From DOE G 435.1-1 Chapter IV: Compliance with these requirements is demonstrated if adequate spare capacity and transfer equipment exists for emergency transfers of all high activity and high hazard liquid low-level waste. In addition, the capability to perform emergency transfers is demonstrated by having waste transfer routings identified, operational procedures to direct transfers, staff trained to the procedures, and records showing that the spare capacity and transfer capability are kept in operating condition.

(2) Transfer Equipment. Pipelines and auxiliary facilities necessary for the transfer of high activity or high hazard liquid low-level waste to contingency storage shall be maintained in an operational condition when waste is present and shall meet the requirements of DOE O 435.1, Radioactive Waste Management, and this Manual.

From DOE G 435.1-1 Chapter IV: Compliance with these requirements is demonstrated if adequate spare capacity and transfer equipment exists for emergency transfers of all high activity and high hazard liquid low-level waste. In addition, the capability to perform emergency transfers is

DOE Manual 435.1-1 §I.1.E(5) addresses the sitewide emergency management system. The INL plan is provided in PLN-114.

NA; this facility does not store liquid LLW.

NA; this facility does not store or treat liquid LLW.

NA; this facility is not a disposal facility. Facility Compliance Information 
Table 1. (continued).

Facility Name: CFA-622 High-Temperature Materials Laboratory

\begin{tabular}{l|}
\hline \multicolumn{1}{|c|}{ Chapter IV, LLW Requirements } \\
\hline $\begin{array}{l}\text { demonstrated by having waste transfer routings identified, } \\
\text { operational procedures to direct transfers, staff trained to } \\
\text { the procedures, and records showing that the spare } \\
\text { capacity and transfer capability are kept in operating } \\
\text { condition. }\end{array}$ \\
\hline
\end{tabular}

F. Corrective Actions. I of this Manual. The following requirements are in addition to those in Chapter [sic]

From DOE G 435.1-1 Chapter IV: Compliance with DOE M 435.1-1 §I.2.G.(1) is demonstrated by records showing what corrective actions were taken to remedy situations in the radioactive waste management system.

Compliance with DOE M 435.1-1 §I.2.G.(2) is demonstrated by having the necessary procedures, mechanisms, and training in place to effect shutdown or curtailment of activities which pose an imminent danger or other serious hazard to workers or the public, or are not protective of the environment.

(1) Order Compliance. Corrective actions shall be implemented whenever necessary to ensure the requirements of DOE O 435.1, Radioactive Waste Management, and this Manual are met.

From DOE G 435.1-1 Chapter IV: If a facility or activity can be allowed to operate while a noncompliant or hazardous condition exists, the allowance and any associated limitations must be defined as part of the facility or activity's radioactive waste management basis, identified as a configuration controlled item in a configuration management plan or included in a revision or modification to an operating procedure or similar controlled documentation.

Compliance with this requirement is demonstrated if a corrective action system addresses noncompliant or hazardous situations involving low-level waste management facilities in a systematic fashion, and allows identification of problems by all personnel.

(2) Operations Curtailment. Operations shall be curtailed or facilities shut down for failure to establish, maintain, or operate consistent with an approved radioactive waste management basis.

From DOE G 435.1-1 Chapter IV: Compliance with this requirement is demonstrated with a documented system of routine assessments to determine whether waste management activities and facilities are operating in accordance with an approved radioactive waste management basis that provides for graded limitations that can be placed on activities and operations that do not have, or are operating outside of, an approved radioactive

The INL-wide procedure addressing problem identification as required by DOE Manual 435.1-1 §I.2.G.(1) is LWP-13840, which implements the laboratory's corrective action system.

The INL-wide procedure addressing shutdown or curtailment of activities as required by DOE Manual 435.1-1 §I.2.G.(2) is LWP-14002.

See F. above.

The approved RWMB establishes the current compliance status at each radioactive waste management facility. Facility assessments are scheduled to ensure waste management activities are conducted in accordance with the approved RWMB. 
Table 1. (continued).

\begin{tabular}{|c|c|}
\hline \multicolumn{2}{|c|}{ Facility Name: CFA-622 High-Temperature Materials Laboratory } \\
\hline Chapter IV, LLW Requirements & Facility Compliance Information \\
\hline $\begin{array}{l}\text { waste management basis, including shutdown of the } \\
\text { facility. }\end{array}$ & \\
\hline $\begin{array}{l}\text { G. Waste Acceptance. The following requirements are in } \\
\text { addition to those in Chapter I of this Manual [DOE M } \\
435.1-1 \text { §I.2.F(6)]. }\end{array}$ & $\begin{array}{l}\text { DOE Manual 435.1-1 §I.2.F(6) applies to field element } \\
\text { managers. }\end{array}$ \\
\hline $\begin{array}{l}\text { (1) Technical and Administrative. Waste acceptance } \\
\text { requirements for all low-level waste storage, treatment, or } \\
\text { disposal facilities, operations, and activities shall specify, } \\
\text { at a minimum, the following: }\end{array}$ & $\begin{array}{l}\text { NA; this facility does not accept LLW from other } \\
\text { facilities. }\end{array}$ \\
\hline $\begin{array}{l}\text { From DOE G 435.1-1 Chapter IV: Compliance with these } \\
\text { waste acceptance requirements is demonstrated if they are } \\
\text { documented, contain clear and precise criteria specifying } \\
\text { the radionuclide limits in the form of contents or } \\
\text { concentrations that can be accepted, the limitations and } \\
\text { prohibitions on waste forms and packages that can be } \\
\text { received, and the limits, prohibitions, or instructions } \\
\text { concerning any other technical information so that the } \\
\text { waste is compatible with the safety basis of the facility, } \\
\text { and which will result in acceptable waste at subsequent } \\
\text { steps in managing the low-level waste. }\end{array}$ & \\
\hline $\begin{array}{l}\text { (a) Allowable activities and/or concentrations of specific } \\
\text { radionuclides. }\end{array}$ & See (1) above. \\
\hline $\begin{array}{l}\text { (b) Acceptable waste form and/or container requirements } \\
\text { that ensure the chemical and physical stability of waste } \\
\text { under conditions that might be encountered during } \\
\text { transportation, storage, treatment, or disposal. }\end{array}$ & See (1) above. \\
\hline $\begin{array}{l}\text { (c) Restrictions or prohibitions on waste, materials, or } \\
\text { containers that may adversely affect waste handlers or } \\
\text { compromise facility or waste container performance. }\end{array}$ & See (1) above. \\
\hline $\begin{array}{l}\text { (d) The following are additional waste acceptance } \\
\text { requirements that shall be specified in low-level waste } \\
\text { disposal facility waste acceptance requirements: }\end{array}$ & See (1) above. \\
\hline $\begin{array}{l}1 \text { Low-level waste must contribute to and not detract from } \\
\text { achieving long-term stability of the facility, minimizing } \\
\text { the need for long-term active maintenance, minimizing } \\
\text { subsidence, and minimizing contact of water with waste. } \\
\text { Void spaces within the waste and, if containers are used, } \\
\text { between the waste and its container shall be reduced to } \\
\text { the extent practical. }\end{array}$ & See (1) above. \\
\hline $\begin{array}{l}2 \text { Liquid low-level waste or low-level waste containing } \\
\text { free liquid must be converted into a form that contains as } \\
\text { little freestanding liquid as is reasonably achievable, but } \\
\text { in no case shall the liquid exceed } 1 \text { percent of the waste } \\
\text { volume when the low-level waste is in a disposal } \\
\text { container, or } 0.5 \text { percent of the waste volume after it is } \\
\text { processed to a stable form. }\end{array}$ & See (1) above. \\
\hline
\end{tabular}


Table 1. (continued).

\begin{tabular}{|c|c|}
\hline \multicolumn{2}{|c|}{ Facility Name: CFA-622 High-Temperature Materials Laboratory } \\
\hline Chapter IV, LLW Requirements & Facility Compliance Information \\
\hline $\begin{array}{l}3 \text { Low-level waste must not be readily capable of } \\
\text { detonation or of explosive decomposition or reaction at } \\
\text { anticipated pressures and temperatures, or of explosive } \\
\text { reaction with water. Pyrophoric materials contained in } \\
\text { waste shall be treated, prepared, and packaged to be } \\
\text { nonflammable. }\end{array}$ & See (1) above. \\
\hline $\begin{array}{l}4 \text { Low-level waste must not contain, or be capable of } \\
\text { generating by radiolysis or biodegradation, quantities of } \\
\text { toxic gases, vapors, or fumes harmful to the public or } \\
\text { workers or disposal facility personnel, or harmful to the } \\
\text { long-term structural stability of the disposal site. }\end{array}$ & See (1) above. \\
\hline $\begin{array}{l}5 \text { Low-level waste in a gaseous form must be packaged } \\
\text { such that the pressure does not exceed } 1.5 \text { atmospheres } \\
\text { absolute at } 20 \mathrm{C} \text {. [ sic }]\end{array}$ & See (1) above. \\
\hline $\begin{array}{l}\text { (e) The basis, procedures, and levels of authority required } \\
\text { for granting exceptions to the waste acceptance } \\
\text { requirements, which shall be contained in each facility's } \\
\text { waste acceptance documentation. Each exception request } \\
\text { shall be documented, including its disposition as approved } \\
\text { or not approved. }\end{array}$ & See (1) above. \\
\hline $\begin{array}{l}\text { From DOE G } 435.1-1 \text { Chapter IV: Waste acceptance } \\
\text { requirements are acceptable if they are documented and } \\
\text { contain a clear description of the procedure and bases for } \\
\text { obtaining an exception or deviation to the acceptance } \\
\text { criteria for low-level waste to be received at the facility. }\end{array}$ & \\
\hline $\begin{array}{l}\text { (2) Evaluation and Acceptance. The receiving facility } \\
\text { shall evaluate waste for acceptance, including } \\
\text { confirmation that the technical and administrative } \\
\text { requirements have been met. A process for the disposition } \\
\text { of non-conforming wastes shall be established. }\end{array}$ & See (1) above. \\
\hline $\begin{array}{l}\text { From DOE G 435.1-1 Chapter IV: Compliance with the } \\
\text { waste acceptance requirements for a low-level waste } \\
\text { management facility is demonstrated if they include a } \\
\text { process for evaluation and acceptance of incoming waste } \\
\text { to ensure the acceptance criteria of the facility receiving } \\
\text { the waste are met that includes one of or a combination } \\
\text { of: (1) testing, sampling, and analysis of representative } \\
\text { samples of waste upon receipt; (2) testing, sampling, and } \\
\text { analysis of split samples of waste taken at the generator } \\
\text { site; (3) evaluation of testing, sampling, and analysis of } \\
\text { data provided by the generator, or (4) audits, reviews, } \\
\text { surveillance, or observations of generator waste } \\
\text { certification programs and characterization activities. } \\
\text { Additionally, acceptable waste acceptance requirements } \\
\text { for a storage, treatment or disposal facility will have } \\
\text { documented procedures and actions to be taken if a waste } \\
\text { that does not conform to the waste acceptance criteria is } \\
\text { received at the facility. }\end{array}$ & \\
\hline
\end{tabular}


Table 1. (continued).

\begin{tabular}{|c|c|}
\hline \multicolumn{2}{|c|}{ Facility Name: CFA-622 High-Temperature Materials Laboratory } \\
\hline Chapter IV, LLW Requirements & Facility Compliance Information \\
\hline $\begin{array}{l}\text { H. Waste Generation Planning. The following } \\
\text { requirements are in addition to those in Chapter I of this } \\
\text { Manual [DOE M 435.1-1 §I.2.F(7)]. }\end{array}$ & $\begin{array}{l}\text { DOE Manual 435.1-1 §I.2.F(7) applies to field element } \\
\text { managers. }\end{array}$ \\
\hline $\begin{array}{l}\text { (1) Life-Cycle Planning. Prior to waste generation, } \\
\text { planning shall be performed to address the entire life } \\
\text { cycle for all low-level waste streams. }\end{array}$ & $\begin{array}{l}\text { PDD-17000 and LWP- } 17000 \text { provide direction to waste } \\
\text { generators for waste generation planning to address the } \\
\text { entire life cycle. }\end{array}$ \\
\hline $\begin{array}{l}\text { From DOE G 435.1-1 Chapter IV: Compliance with this } \\
\text { planning requirement is demonstrated by the individual } \\
\text { sites establishing a process for evaluating the life-cycle of } \\
\text { low-level waste prior to its generation, including the } \\
\text { identification of low-level wastes with no path to disposal } \\
\text { and appropriate records justifying the newly generated } \\
\text { low-level waste stream(s), and site personnel possessing } \\
\text { planning information showing the location(s) where low- } \\
\text { level waste will be stored, treated, and/or disposed along } \\
\text { with a confirmation that the personnel managing the } \\
\text { facilities agree that the low-level waste may be managed } \\
\text { at those facilities. }\end{array}$ & $\begin{array}{l}\text { Form } 435.39 \text { and Form } 435.42 \text { are used to identify } \\
\text { radioactive LLW. }\end{array}$ \\
\hline $\begin{array}{l}\text { (2) Waste with No Identified Path to Disposal. Low-level } \\
\text { waste streams with no identified path to disposal shall be } \\
\text { generated only in accordance with approved conditions } \\
\text { which, at a minimum, shall address: }\end{array}$ & $\begin{array}{l}\text { This facility is not generating radioactive waste that } \\
\text { does not have an identified path to disposal. }\end{array}$ \\
\hline (a) Programmatic need to generate the waste; & See (2) above. \\
\hline $\begin{array}{l}\text { (b) Characteristics and issues preventing the disposal of } \\
\text { the waste; }\end{array}$ & See (2) above. \\
\hline $\begin{array}{l}\text { (c) Safe storage of the waste until disposal can be } \\
\text { achieved; and }\end{array}$ & See (2) above. \\
\hline $\begin{array}{l}\text { (d) Activities and plans for achieving final disposal of the } \\
\text { waste. }\end{array}$ & See (2) above. \\
\hline $\begin{array}{l}\text { I. Waste Characterization. Low-level waste shall be } \\
\text { characterized using direct or indirect methods, and the } \\
\text { characterization documented in sufficient detail to ensure }\end{array}$ & $\begin{array}{l}\text { MCP-17000 } \$ 4 \text { specifies the requirements for preparing } \\
\text { an Integrated Waste Tracking System (IWTS) profile } \\
\text { that captures waste characterization information. }\end{array}$ \\
\hline $\begin{array}{l}\text { safe management and compliance with the waste } \\
\text { acceptance requirements of the facility receiving the } \\
\text { waste. }\end{array}$ & $\begin{array}{l}\text { Individual laboratory projects have project-specific } \\
\text { laboratory instructions that address management of } \\
\text { LLW and mixed LLW in accordance with INL }\end{array}$ \\
\hline From DOE G 435.1-1 Chapter IV: Compliance with this & Manual 17's waste management requirements. \\
\hline $\begin{array}{l}\text { documenting and the existence of records that document } \\
\text { the process for acquiring and verifying the validity of } \\
\text { low-level waste characterization data acquired through the } \\
\text { use of direct or indirect methods. }\end{array}$ & $\begin{array}{l}\text { Laboratory Instruction } 1529-09-\text { CFA, Table } 2.03 \\
\text { provides very general characterization information } \\
\text { regarding the waste types and volumes generated } \\
\text { subsequent to routine laboratory operations. The table } \\
\text { also provides the method of disposal. }\end{array}$ \\
\hline $\begin{array}{l}\text { (1) Data Quality Objectives. The data quality objectives } \\
\text { process, or a comparable process, shall be used for } \\
\text { identifying characterization parameters and acceptable } \\
\text { uncertainty in characterization data. }\end{array}$ & $\begin{array}{l}\text { Radioactive waste management facilities characterize } \\
\text { waste in accordance with the requirements of the } \\
\text { receiving storage, treatment, or disposal facility. The } \\
\text { documented use of a data quality objectives process, or }\end{array}$ \\
\hline
\end{tabular}


Table 1. (continued).

\begin{tabular}{|c|c|}
\hline \multicolumn{2}{|c|}{ Facility Name: CFA-622 High-Temperature Materials Laboratory } \\
\hline Chapter IV, LLW Requirements & Facility Compliance Information \\
\hline $\begin{array}{l}\text { From DOE G } 435.1-1 \text { Chapter IV: Compliance with this } \\
\text { requirement is demonstrated by the documented use of a } \\
\text { data quality objectives or a comparable process for } \\
\text { determining the type, quantity, and quality of } \\
\text { characterization data needed to safely manage low-level } \\
\text { waste. }\end{array}$ & comparable process, was not identified for this facility. \\
\hline $\begin{array}{l}\text { (2) Minimum Waste Characterization. Characterization } \\
\text { data shall, at a minimum, include the following } \\
\text { information relevant to the management of the waste: }\end{array}$ & $\begin{array}{l}\text { MCP- } 17000 \S 4 \text { specifies the requirements for preparing } \\
\text { an IWTS profile that captures waste characterization } \\
\text { information. }\end{array}$ \\
\hline \multirow{2}{*}{$\begin{array}{l}\text { From DOE G } 435.1-1 \text { Chapter IV: Compliance with this } \\
\text { requirement is demonstrated by the existence of a } \\
\text { program or procedure for determining and records that } \\
\text { document characterization of low-level waste consistent } \\
\text { with the minimum characterization data requirements. }\end{array}$} & $\begin{array}{l}\text { Individual laboratory projects have project-specific } \\
\text { laboratory instructions that address the management of } \\
\text { LLW and mixed LLW in accordance with INL } \\
\text { Manual 17's waste management requirements. }\end{array}$ \\
\hline & $\begin{array}{l}\text { Laboratory Instruction } 1529-09-\text { CFA, Table } 2.03 \\
\text { provides very general characterization information } \\
\text { regarding the waste types and volumes generated } \\
\text { subsequent to routine laboratory operations. The table } \\
\text { also provides the method of disposal. }\end{array}$ \\
\hline (a) Physical and chemical characteristics; & See (2) above. \\
\hline $\begin{array}{l}\text { (b) Volume, including the waste and any stabilization or } \\
\text { absorbent media; }\end{array}$ & See (2) above. \\
\hline (c) Weight of the container and contents; & See (2) above. \\
\hline $\begin{array}{l}\text { (d) Identities, activities, and concentrations of major } \\
\text { radionuclides; }\end{array}$ & See (2) above. \\
\hline (e) Characterization date; & See (2) above. \\
\hline (f) Generating source; and & See (2) above. \\
\hline $\begin{array}{l}\text { (g) Any other information which may be needed to } \\
\text { prepare and maintain the disposal facility performance } \\
\text { assessment, or demonstrate compliance with applicable } \\
\text { performance objectives. }\end{array}$ & See (2) above. \\
\hline \multirow{6}{*}{$\begin{array}{l}\text { J. Waste Certification. A waste certification program shall } \\
\text { be developed, documented, and implemented to ensure } \\
\text { that the waste acceptance requirements of facilities } \\
\text { receiving low-level waste for storage, treatment, and } \\
\text { disposal are met. } \\
\text { From DOE G 435.1-1 Chapter IV: Compliance with the } \\
\text { development and documentation portion of the } \\
\text { certification requirement is demonstrated by a waste } \\
\text { certification plan that identifies the organizations } \\
\text { involved, assigns responsibilities for implementing the } \\
\text { program, and describes or references the quality } \\
\text { assurance, training, procurement controls, records } \\
\text { management, and procedures to be used by the program. } \\
\text { Acceptable performance for implementing the program is }\end{array}$} & $\begin{array}{l}\text { MCP- } 17000 \S 4 \text { specifies the requirements for preparing } \\
\text { an IWTS profile that captures waste certification } \\
\text { information. }\end{array}$ \\
\hline & $\begin{array}{l}\text { MCP-17500 provides the Waste Generator Services } \\
\text { Waste Certification Program for LLW to be shipped to }\end{array}$ \\
\hline & the Nevada National Security Site (NNSS). \\
\hline & $\begin{array}{l}\text { Container procurement is addressed in MCP- } 17000 \text {, } \\
\S 4.6 \text {. }\end{array}$ \\
\hline & $\begin{array}{l}\text { Waste certification is performed and tracked using } \\
\text { IWTS. Documentation of the IWTS program is } \\
\text { available only electronically. }\end{array}$ \\
\hline & $\begin{array}{l}\text { PLN-522 requires waste technical specialists and waste } \\
\text { disposition specialists to complete the appropriate }\end{array}$ \\
\hline
\end{tabular}


Table 1. (continued).

\section{Facility Name: CFA-622 High-Temperature Materials Laboratory}

Chapter IV, LLW Requirements

demonstrated when appropriate personnel are trained and follow the procedures that govern their part of the waste certification. Additionally, acceptable performance is demonstrated if the waste certification plan and procedures are current and controlled in accordance with a document controls program, and records related to certification (e.g., certification statements, training records, procurement records, characterization records, container records) are generated and managed in accordance with the established site program.

(1) Certification Program. The waste certification program shall designate the officials who have the authority to certify and release waste for shipment; and specify what documentation is required for waste generation, characterization, shipment, and certification. The program shall provide requirements for auditability, retrievability, and storage of required documentation and specify the records retention period.

From DOE G 435.1-1 Chapter IV: Compliance with this requirement is demonstrated by a program or procedure for record keeping and records showing that low-level waste is certified as having met the waste acceptance criteria of the facility to which it was transferred and that the certification statement is supported by additional records regarding the waste source, characterization, and container.

(2) Certification before Transfer. Low-level waste shall be certified as meeting waste acceptance requirements before it is transferred to the facility receiving the waste.

From DOE G 435.1-1 Chapter IV: Compliance with this requirement is demonstrated by the presence of a certification program which includes procedures requiring a signed certification statement prior to the release of waste for transfer, and by dated records showing that waste was certified before being transferred.

(3) Maintaining Certification. Low-level waste that has been certified as meeting the waste acceptance requirements for transfer to a storage, treatment, or disposal facility shall be managed in a manner that maintains its certification status.

From DOE G 435.1-1 Chapter IV: Compliance with this requirement is demonstrated by a program or procedure reflecting this requirement is present and site personnel are able to show that the storage of low-level waste containers is in a facility or manner where the containers would not be damaged by normal weather events, and cannot be accessed by unauthorized personnel. Further, each container can be traced to its certification and the

\section{Facility Compliance Information}

training/qualification before being granted approval authority for profiles within the IWTS Program. The waste certification official, alternate waste certification official, and NNSS packaging certifiers must complete the appropriate training/qualifications to disposition waste to NNSS.

See J. above.

See J. above.

See J. above. 
Table 1. (continued).

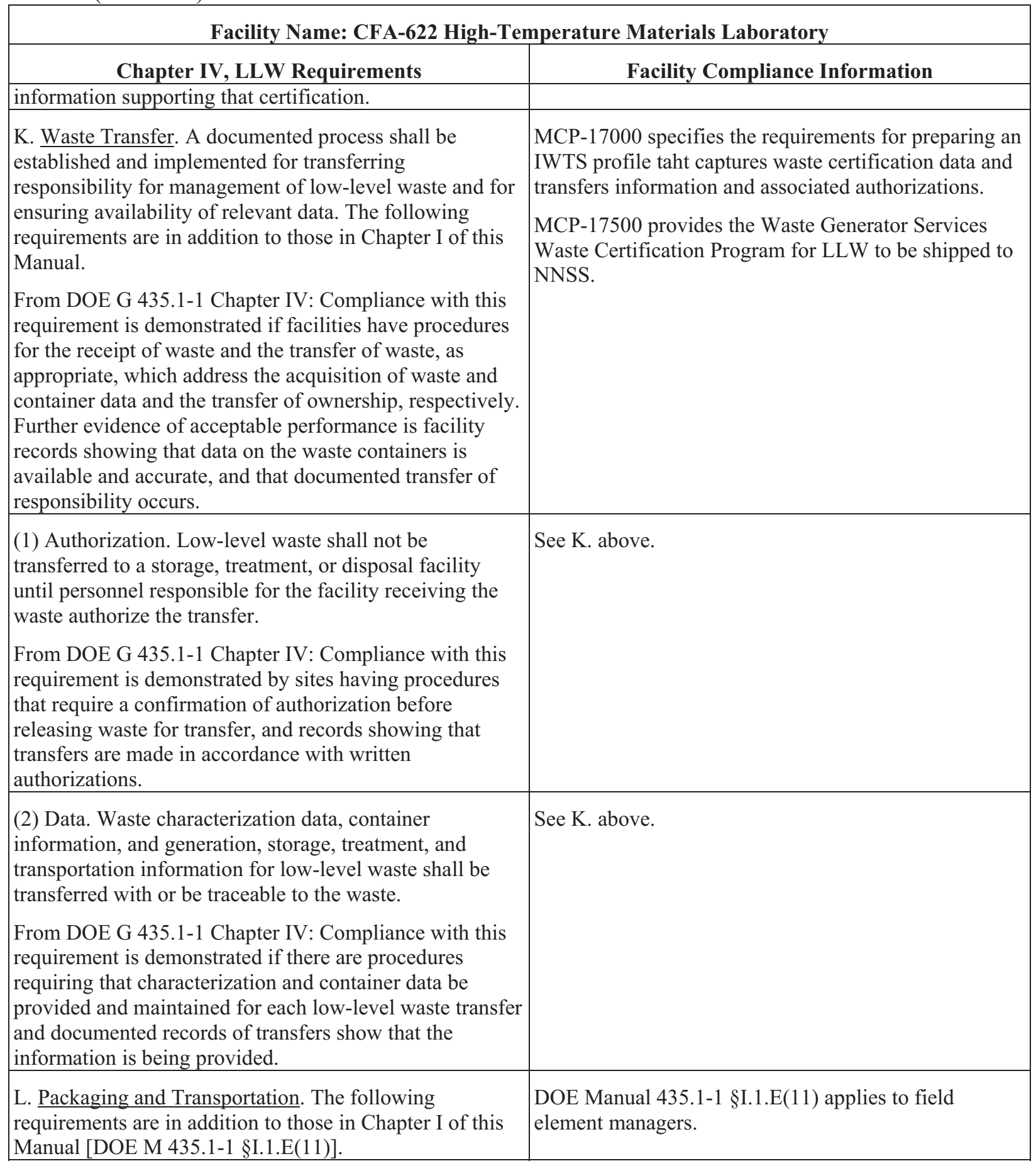


Table 1. (continued).

\begin{tabular}{|c|c|}
\hline \multicolumn{2}{|c|}{ Facility Name: CFA-622 High-Temperature Materials Laboratory } \\
\hline Chapter IV, LLW Requirements & Facility Compliance Information \\
\hline (1) Packaging. If containers are used: & MCP- $17000 \S 4$. addresses packaging requirements. \\
\hline $\begin{array}{l}\text { From DOE G 435.1-1 Chapter IV: Compliance with the } \\
\text { packaging requirement is demonstrated by: (1) procedures } \\
\text { which document proper packaging protocols; and (2) no } \\
\text { trends of routine repackaging of low-level waste that is } \\
\text { packaged after issuance of DOE O } 435.1 \text {. Successful } \\
\text { performance of this requirement is also demonstrated by a } \\
\text { record of containers for which failure has not routinely } \\
\text { occurred under management conditions. It is recognized } \\
\text { that there may be failed containers for waste previously } \\
\text { placed in storage. For those containers, the goal is to only } \\
\text { have to repackage the waste one time after it is retrieved } \\
\text { and characterized. Further, acceptable performance is } \\
\text { demonstrated by containers of waste having marking and } \\
\text { labeling that allows correlation with waste } \\
\text { characterization data and container information. }\end{array}$ & \\
\hline $\begin{array}{l}\text { (a) Low-level waste shall be packaged in a manner that } \\
\text { provides containment and protection for the duration of } \\
\text { the anticipated storage period and until disposal is } \\
\text { achieved or until the waste has been removed from the } \\
\text { container. }\end{array}$ & See (1) above. \\
\hline $\begin{array}{l}\text { (b) When waste is packaged, vents or other measures shall } \\
\text { be provided if the potential exists for pressurizing or } \\
\text { generating flammable or explosive concentrations of } \\
\text { gases within the waste container. }\end{array}$ & See (1) above. \\
\hline $\begin{array}{l}\text { (c) Containers of low-level waste shall be marked such } \\
\text { that their contents can be identified. }\end{array}$ & See (1) above. \\
\hline $\begin{array}{l}\text { (2) Transportation. To the extent practical, the volume of } \\
\text { waste and number of low-level waste shipments shall be } \\
\text { minimized. }\end{array}$ & $\begin{array}{l}\text { NA; waste is not shipped to an offsite facility for final } \\
\text { disposition from this facility. }\end{array}$ \\
\hline $\begin{array}{l}\text { From DOE G } 435.1-1 \text { Chapter IV: Compliance with this } \\
\text { requirement can be demonstrated by a combination of site } \\
\text { procedures directing the efficient use of waste container } \\
\text { capacity and documentation showing that low-level waste } \\
\text { shipments are systematically planned and optimized to the } \\
\text { extent practical. }\end{array}$ & \\
\hline $\begin{array}{l}\text { M. Site Evaluation and Facility Design. The following } \\
\text { requirements are in addition to those in Chapter I of this } \\
\text { Manual. }\end{array}$ & $\begin{array}{l}\text { NA; this requirement addresses new radioactive waste } \\
\text { management facilities. }\end{array}$ \\
\hline $\begin{array}{l}\text { (1) Site Evaluation. Proposed locations for low-level } \\
\text { waste facilities shall be evaluated to identify relevant } \\
\text { features that should be avoided or must be considered in } \\
\text { facility design and analyses. }\end{array}$ & See M. above. \\
\hline
\end{tabular}


Table 1. (continued).

Facility Name: CFA-622 High-Temperature Materials Laboratory

Chapter IV, LLW Requirements

(a) Each site proposed for a new low-level waste facility or expansion of an existing low-level waste facility shall be evaluated considering environmental characteristics, geotechnical characteristics, and human activities, including for a low-level waste disposal facility, the capability of the site to demonstrate, at a minimum, whether it is:

1 Located to accommodate the projected volume of waste to be received;

2 Located in a flood plain, a tectonically active area, or in the zone of water table fluctuation; and

3 Located where radionuclide migration pathways are predictable and erosion and surface runoff can be controlled.

(b) Proposed sites with environmental characteristics, geotechnical characteristics, and human activities for which adequate protection cannot be provided through facility design shall be deemed unsuitable for the location of the facility.

(c) Low-level waste disposal facilities shall be sited to achieve long-term stability and to minimize, to the extent practical, the need for active maintenance following final closure.

(2) Low-Level Waste Treatment and Storage Facility Design. The following facility requirements and general design criteria, at a minimum, apply:

(a) Confinement. Low-level waste systems and components shall be designed to maintain waste confinement.

(b) Ventilation.

1 Design of low-level waste treatment and storage facilities shall include ventilation, if applicable, through an appropriate filtration system to maintain the release of radioactive material in airborne effluents within the requirements and guidelines specified in applicable requirements.

2 When conditions exist for generating gases in flammable or explosive concentrations, ventilation systems or other measures shall be provided to keep the gases in a non-flammable and nonexplosive condition. Where concentrations of explosive or flammable gases are expected to approach the lower flammability limit, measures shall be taken to prevent deflagration or detonation.

\section{Facility Compliance Information}

See M. above.

See M. above.

See M. above.

See M. above.

See M. above.

See M. above.

See M. above.

See M. above.

See M. above.

See M. above.

See M. above. 
Table 1. (continued).

Facility Name: CFA-622 High-Temperature Materials Laboratory

\begin{tabular}{l} 
Chapter IV, LLW Requirements \\
\hline (c) Consideration of Decontamination and \\
Decommissioning. Areas in new and modifications to \\
existing low-level waste management facilities that are \\
subject to contamination with radioactive or other \\
hazardous materials shall be designed to facilitate \\
decontamination. For such facilities a proposed \\
decommissioning method or a conversion method leading \\
to reuse shall be described.
\end{tabular}

(d) Instrumentation and Control Systems. Engineering controls shall be incorporated in the design and engineering of low-level waste treatment and storage facilities to provide volume inventory data and to prevent spills, leaks, and overflows from tanks or confinement systems.

(e) Monitoring. Monitoring and/or leak detection capabilities shall be incorporated in the design and engineering of low-level waste treatment and storage facilities to provide rapid identification of failed confinement and/or other abnormal conditions.

(3) Low-Level Waste Disposal Facility Design. The following facility requirements and general design criteria, at a minimum, apply:

(a) Confinement. Low-level waste systems and components shall be designed to maintain waste confinement.

(b) Ventilation.

1 Design of low-level waste disposal facilities shall include ventilation, if applicable, through an appropriate filtration system to maintain the release of radioactive material in airborne effluents within the requirements and guidelines specified in applicable requirements.

2 When conditions exist for generating gases in flammable or explosive concentrations, ventilation systems or other measures shall be provided to keep the gases in a nonflammable and non-explosive condition. Where concentrations of explosive or flammable gases are expected to approach the lower flammability limit, measures shall be taken to prevent deflagration or detonation.

(c) Stability. Low-level waste disposal facilities shall be designed to achieve long-term stability and to minimize to the extent practical, the need for active maintenance following final closure.

(d) Control of Water. Low-level waste disposal facilities shall be designed to minimize to the extent practical, the contact of waste with water during and after disposal.

See M. above. Facility Compliance Information

See M. above.

See M. above.

See M. above.

See M. above.

See M. above.

See M. above.

See M. above.

See M. above. to See M. above. are 
Table 1. (continued).

\begin{tabular}{|c|c|}
\hline \multicolumn{2}{|c|}{ Facility Name: CFA-622 High-Temperature Materials Laboratory } \\
\hline Chapter IV, LLW Requirements & Facility Compliance Information \\
\hline $\begin{array}{l}\text { N. Storage and Staging. The following requirements are } \\
\text { in addition to those in Chapter I of this Manual [DOE M } \\
435.1-1 \text { §I.2.F(13)]. }\end{array}$ & $\begin{array}{l}\text { DOE Manual 435.1-1 §I.2.F(13) applies to field } \\
\text { element managers. }\end{array}$ \\
\hline $\begin{array}{l}\text { (1) Storage Prohibitions. Low-level waste in storage shall } \\
\text { not be readily capable of detonation, explosive } \\
\text { decomposition, reaction at anticipated pressures and } \\
\text { temperatures, or explosive reaction with water. Prior to } \\
\text { storage, pyrophoric materials shall be treated, prepared, } \\
\text { and packaged to be nonflammable. }\end{array}$ & NA; this facility does not store LLW. \\
\hline $\begin{array}{l}\text { From DOE G } 435.1-1 \text { Chapter IV: Compliance with this } \\
\text { requirement is demonstrated by having waste acceptance } \\
\text { requirements which prohibit low-level waste that is } \\
\text { ignitable or explosive from being accepted for storage } \\
\text { unless it has been treated, and procedures for properly } \\
\text { preparing such materials for safe storage. }\end{array}$ & \\
\hline $\begin{array}{l}\text { (2) Storage Limit. Low-level waste that has an identified } \\
\text { path to disposal shall not be stored longer than one year } \\
\text { prior to disposal, except for storage for decay, or as } \\
\text { otherwise authorized by the Field Element Manager. }\end{array}$ & $\begin{array}{l}\text { NA; this facility does not store LLW. See N. (7) below } \\
\text { for staging requirements. }\end{array}$ \\
\hline $\begin{array}{l}\text { From DOE G } 435.1-1 \text { Chapter IV: Storage longer than } \\
\text { one year can be justified if the conditions for such storage } \\
\text { are approved by the Field Element Manager as part of the } \\
\text { radioactive waste management basis for the facility. }\end{array}$ & \\
\hline $\begin{array}{l}\text { Storage for radioactive decay for a period greater than } 1 \\
\text { year for waste that has an identified path to disposal is } \\
\text { allowed. Adequate justification and the supporting } \\
\text { information for storage for decay is to be documented in } \\
\text { the radioactive waste management basis for the facility in } \\
\text { which the storage will take place. }\end{array}$ & \\
\hline $\begin{array}{l}\text { Mixed waste. Under the Federal Facility Compliance Act } \\
\text { of 1992, DOE sites were required to develop Site } \\
\text { Treatment Plans to bring stored mixed low-level waste } \\
\text { into compliance with these requirements. The Site } \\
\text { Treatment Plan needs to be consulted and any mixed low- } \\
\text { level waste stored for the purpose of accumulation to } \\
\text { facilitate treatment must meet Resource Conservation and } \\
\text { Recovery Act storage requirements. There could be } \\
\text { several ways within different scenarios that this } \\
\text { requirement can be met, as illustrated by the examples } \\
\text { below, however, there are basically four ways to show } \\
\text { compliance with the requirement and include appropriate } \\
\text { provisions in the radioactive waste management basis for } \\
\text { the facility in which it is stored. }\end{array}$ & \\
\hline $\begin{array}{l}\text { Legacy waste. As discussed above, the intention of the } \\
\text { requirement is not to force malicious compliance or } \\
\text { heroic actions which would result in increased risk or } \\
\text { safety concerns. Rather, the intention is that waste in }\end{array}$ & \\
\hline
\end{tabular}


Table 1. (continued).

Facility Name: CFA-622 High-Temperature Materials Laboratory

storage longer than one year receives additional attention

to ensure that the public, the workers, and the

environment are protected from the hazards of the waste, and that progress is being made to dispose of the waste.

There could be several ways within different scenarios that this requirement can be met, as illustrated by the examples below, however, there are basically four ways to show compliance with the requirement:

1) the radioactive waste management basis allows for storage for no more than one year.

2) the radioactive waste management basis allows for storage for no more than one year, or for storage for decay only for periods greater than a year, which are specified on a radionuclide basis.

3) the radioactive waste management basis allows for storage for more than one year, up to a specified period of time based on a documented technical evaluation that the waste can be stored in a manner that does not cause changes to the waste or waste packages that is detrimental to the safe storage of the waste, the final disposal of the waste or to meeting the disposal performance objectives.

4) the radioactive waste management basis allows for storage for decay (with specifics) and for storage for more than one year for other low-level waste, up to a specified period of time based on a documented technical evaluation that the waste can be stored in a manner that does not cause changes to the waste or waste packages that is detrimental to the safe storage of the waste, the final disposal of the waste or to meeting the disposal performance objectives.

Compliance with this requirement is demonstrated by the existence of a radioactive waste management basis for the storage facility approved by the Field Element Manager that includes the time frames that waste are allowed to be stored, the necessary justifications for storage for decay, and the necessary technical evaluations if storage is to extend significantly beyond the one-year time frame.

(3) Storage Integrity. Low-level waste shall be stored in a location and manner that protects the integrity of waste for the expected time of storage and minimizes worker exposure.

From DOE G 435.1-1 Chapter IV: However, in making a decision to use a facility for storage and in developing a radioactive waste management basis for the activity, particular attention to protection of workers is needed.

Compliance with this requirement is demonstrated if sites have storage capabilities for low-level waste that provide

NA; this facility does not store LLW. See N. (7) below for staging requirements. 
Table 1. (continued).

\begin{tabular}{|c|c|}
\hline \multicolumn{2}{|c|}{ Facility Name: CFA-622 High-Temperature Materials Laboratory } \\
\hline Chapter IV, LLW Requirements & Facility Compliance Information \\
\hline $\begin{array}{l}\text { protection to waste containers so that their integrity will } \\
\text { not be damaged through physical or chemical (corrosion) } \\
\text { processes and that keep personnel from spending } \\
\text { extended periods of time in the areas where low-level } \\
\text { waste is stored. }\end{array}$ & \\
\hline (4) Waste Characterization for Storage. & $\begin{array}{l}\text { NA; this facility does not store LLW. See N. (7) below } \\
\text { for staging requirements. }\end{array}$ \\
\hline $\begin{array}{l}\text { (a) Low-level waste that does not have an identified path } \\
\text { to disposal shall be characterized as necessary to meet the } \\
\text { data quality objectives and minimum characterization } \\
\text { requirements of this Chapter, to ensure safe storage, and } \\
\text { to facilitate disposal. }\end{array}$ & $\begin{array}{l}\text { NA; this facility does not store LLW. See N. (7) below } \\
\text { for staging requirements. }\end{array}$ \\
\hline $\begin{array}{l}\text { (b) Characterization information for all low-level waste in } \\
\text { storage shall be maintained as a record in accordance with } \\
\text { the requirements for Records Management in Chapter I of } \\
\text { this Manual. }\end{array}$ & $\begin{array}{l}\text { NA; this facility does not store LLW. See N. (7) below } \\
\text { for staging requirements. }\end{array}$ \\
\hline $\begin{array}{l}\text { From DOE G 435.1-1 Chapter IV: Compliance with this } \\
\text { requirement is demonstrated by documented procedures } \\
\text { for managing waste characterization and container } \\
\text { information on low-level waste as a Federal record. The } \\
\text { records are managed per the applicable policies and } \\
\text { procedures for records management referenced in DOE O } \\
200.1 \text { and established at the applicable Field Element. }\end{array}$ & \\
\hline $\begin{array}{l}\text { (5) Container Inspection. A process shall be developed } \\
\text { and implemented for inspecting and maintaining } \\
\text { containers of low-level waste to ensure container integrity } \\
\text { is not compromised. }\end{array}$ & $\begin{array}{l}\text { LI- } 435 \text { requires quarterly inspections of radioactive } \\
\text { waste containers if waste is stored outdoors or has been } \\
\text { in storage for greater than } 1 \text { year. }\end{array}$ \\
\hline $\begin{array}{l}\text { From DOE G 435.1-1 Chapter IV: Compliance with this } \\
\text { requirement is demonstrated by: (1) a documented process } \\
\text { for waste container inspection and maintenance; and ( } 2) \\
\text { documentation for all waste container inspections and } \\
\text { maintenance actions performed. }\end{array}$ & \\
\hline $\begin{array}{l}\text { (6) Storage Management. Low-level waste storage shall } \\
\text { be managed to identify and segregate low-level waste } \\
\text { from mixed low-level waste. }\end{array}$ & $\begin{array}{l}\text { NA; this facility does not store LLW. See N. (7) below } \\
\text { for staging requirements. }\end{array}$ \\
\hline $\begin{array}{l}\text { (7) Staging. Staging of low-level waste shall be for the } \\
\text { purpose of the accumulation of such quantities of waste as } \\
\text { necessary to facilitate transportation, treatment, and } \\
\text { disposal. Staging longer than } 90 \text { days shall meet the } \\
\text { requirements for storage above and in Chapter I of this } \\
\text { Manual. }\end{array}$ & $\begin{array}{l}\text { Routine LLW, such as personal protective equipment, } \\
\text { is accumulated at this facility for disposal. MCP-17000, } \\
\text { Appendix F, "Container Start Date and Storage } \\
\text { Prohibitions," restricts staging LLW to a } 90 \text {-day } \\
\text { maximum at any generator or treatment facility prior to } \\
\text { acceptance by a storage facility. }\end{array}$ \\
\hline $\begin{array}{l}\text { From DOE G 435.1-1 Chapter IV: The staging of low- } \\
\text { level waste needs to be addressed in the radioactive waste } \\
\text { management basis for the facility that is performing the } \\
\text { staging. Generators, treatment facilities, and disposal } \\
\text { facilities that stage waste must ensure that the action of } \\
\text { staging is included and authorized as part of their }\end{array}$ & $\begin{array}{l}\text { As stated in DOE Guide } 435.1-1 \text { §IV.N.(7), staging } \\
\text { waste in accordance with this requirement allows waste } \\
\text { to be accumulated without being considered storage and } \\
\text { being bound by the associated storage requirements. }\end{array}$ \\
\hline
\end{tabular}


Table 1. (continued).

Facility Name: CFA-622 High-Temperature Materials Laboratory

\begin{tabular}{|c|c|}
\hline Chapter IV, LLW Requirements & Facility Compliance Information \\
\hline \multirow{3}{*}{\multicolumn{2}{|c|}{$\begin{array}{l}\text { radioactive waste management basis for the affected } \\
\text { facilities, operations, or activities. } \\
\text { Staging longer than } 90 \text { days must be justified, the } \\
\text { conditions for such storage met, and these practices } \\
\text { approved by the Field Element Manager as part of the } \\
\text { radioactive waste management basis for the facility. } \\
\text { Compliance with this requirement is demonstrated by a } \\
\text { staging program that limits the temporary storage of waste } \\
\text { to only circumstances allowed in the requirement, } \\
\text { including justifications for any staging that exceeds the } \\
\text { 90-day period, which is documented in the radioactive } \\
\text { waste management basis for the facility. }\end{array}$}} \\
\hline & \\
\hline & \\
\hline $\begin{array}{l}\text { O. Treatment. Low-level waste treatment to provide more } \\
\text { stable waste forms and to improve the long-term } \\
\text { performance of a low-level waste disposal facility shall be } \\
\text { implemented as necessary to meet the performance } \\
\text { objectives of the disposal facility. }\end{array}$ & NA; this facility does not treat LLW. \\
\hline $\begin{array}{l}\text { From DOE G 435.1-1 Chapter IV: Compliance with this } \\
\text { requirement is demonstrated when a treatment facility or } \\
\text { process ensures that treated waste will meet the minimum } \\
\text { waste form requirements of DOE M } 435.1 \text { and meet } \\
\text { additional disposal facility-specific waste acceptance } \\
\text { requirements for additional stability or long-term } \\
\text { performance of facilities that will receive the treated } \\
\text { waste. }\end{array}$ & \\
\hline $\begin{array}{l}\text { P. Disposal. Low-level waste disposal facilities shall meet } \\
\text { the following requirements. }\end{array}$ & NA; this facility does not dispose of LLW. \\
\hline $\begin{array}{l}\text { (1) Performance Objectives. Low-level waste disposal } \\
\text { facilities shall be sited, designed, operated, maintained, } \\
\text { and closed so that a reasonable expectation exists that the } \\
\text { following performance objectives will be met for waste } \\
\text { disposed of after September 26, 1988: }\end{array}$ & See P. above. \\
\hline $\begin{array}{l}\text { (a) Dose to representative members of the public shall not } \\
\text { exceed } 25 \mathrm{mrem}(0.25 \mathrm{mSv}) \text { in a year total effective dose } \\
\text { equivalent from all exposure pathways, excluding the } \\
\text { dose from radon and its progeny in air. }\end{array}$ & See P. above. \\
\hline $\begin{array}{l}\text { (b) Dose to representative members of the public via the } \\
\text { air pathway shall not exceed } 10 \mathrm{mrem}(0.10 \mathrm{mSv}) \text { in a } \\
\text { year total effective dose equivalent, excluding the dose } \\
\text { from radon and its progeny. }\end{array}$ & See P. above. \\
\hline $\begin{array}{l}\text { (c) Release of radon shall be less than an average flux of } \\
20 \mathrm{pCi} / \mathrm{m}^{2} / \mathrm{s}\left(0.74 \mathrm{~Bq} / \mathrm{m}^{2} / \mathrm{s}\right) \text { at the surface of the disposal } \\
\text { facility. Alternatively, a limit of } 0.5 \mathrm{pCi} / 1(0.0185 \mathrm{~Bq} / 1) \text { of } \\
\text { air may be applied at the boundary of the facility. }\end{array}$ & See P. above. \\
\hline $\begin{array}{l}\text { (2) Performance Assessment. A site-specific radiological } \\
\text { performance assessment shall be prepared and maintained }\end{array}$ & See P. above. \\
\hline
\end{tabular}


Table 1. (continued).

Facility Name: CFA-622 High-Temperature Materials Laboratory

\begin{tabular}{l} 
Chapter IV, LLW Requirements \\
\hline for DOE low-level waste disposed of after September 26, \\
1988. The performance assessment shall include \\
calculations for a 1,000 year period after closure of \\
potential doses to representative future members of the \\
public and potential releases from the facility to provide a \\
reasonable expectation that the performance objectives \\
identified in this Chapter are not exceeded as a result of \\
operation and closure of the facility.
\end{tabular}

(a) Analyses performed to demonstrate compliance with the performance objectives in this Chapter, and to establish limits on concentrations of radionuclides for disposal based on the performance measures for inadvertent intruders in this Chapter shall be based on reasonable activities in the critical group of exposed individuals. Unless otherwise specified, the assumption of average living habits and exposure conditions in representative critical groups of individuals projected to receive the highest doses is appropriate. The likelihood of inadvertent intruder scenarios may be considered in interpreting the results of the analyses and establishing radionuclide concentrations, if adequate justification is provided.

(b) The point of compliance shall correspond to the point $\quad$ See P. above. of highest projected dose or concentration beyond a 100 meter buffer zone surrounding the disposed waste. A larger or smaller buffer zone may be used if adequate justification is provided.

(c) Performance assessments shall address reasonably foreseeable natural processes that might disrupt barriers against release and transport of radioactive materials.

(d) Performance assessments shall use DOE-approved dose coefficients (dose conversion factors) for internal and external exposure of reference adults.

(e) The performance assessment shall include a sensitivity/uncertainty analysis.

(f) Performance assessments shall include a

See P. above. Facility Compliance Information

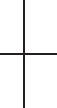

Facility Compliance Information

demonstration that projected releases of radionuclides to

the environment shall be maintained as low as reasonably achievable (ALARA).

(g) For purposes of establishing limits on radionuclides that may be disposed of near-surface, the performance assessment shall include an assessment of impacts to water resources.

(h) For purposes of establishing limits on the concentration of radionuclides that may be disposed of near-surface, the performance assessment shall include an assessment of impacts calculated for a hypothetical person
See P. above.

See P. above.

See P. above.

See P. above.

See P. above.

See P. above.

See P. above. 
Table 1. (continued).

Facility Name: CFA-622 High-Temperature Materials Laboratory

\begin{tabular}{|c|}
\hline Chapter IV, LLW Requirements \\
\hline $\begin{array}{l}\text { assumed to inadvertently intrude for a temporary period } \\
\text { into the low-level waste disposal facility. For intruder } \\
\text { analyses, institutional controls shall be assumed to be } \\
\text { effective in deterring intrusion for at least } 100 \text { years } \\
\text { following closure. The intruder analyses shall use } \\
\text { performance measures for chronic and acute exposure } \\
\text { scenarios, respectively, of } 100 \text { mrem }(1 \mathrm{mSv}) \text { in a year } \\
\text { and } 500 \text { mrem ( } 5 \mathrm{mSv}) \text { total effective dose equivalent } \\
\text { excluding radon in air. }\end{array}$ \\
\hline
\end{tabular}

(3) Composite Analysis. For disposal facilities which received waste after September 26, 1988, a site-specific radiological composite analysis shall be prepared and maintained that accounts for all sources of radioactive material that may be left at the DOE site and may interact with the low- level waste disposal facility, contributing to the dose projected to a hypothetical member of the public from the existing or future disposal facilities. Performance measures shall be consistent with DOE requirements for protection of the public and environment and evaluated for a 1,000 year period following disposal facility closure. The composite analysis results shall be used for planning, radiation protection activities, and future use commitments to minimize the likelihood that current lowlevel waste disposal activities will result in the need for future corrective or remedial actions to adequately protect the public and the environment.

(4) Performance Assessment and Composite Analysis Maintenance. The performance assessment and composite analysis shall be maintained to evaluate changes that could affect the performance, design, and operating bases for the facility. Performance assessment and composite analysis maintenance shall include the conduct of research, field studies, and monitoring needed to address uncertainties or gaps in existing data. The performance assessment shall be updated to support the final facility closure. Additional iterations of the performance assessment and composite analysis shall be conducted as necessary during the post-closure period.

(a) Performance assessments and composite analyses shall be reviewed and revised when changes in waste forms or containers, radionuclide inventories, facility design and operations, closure concepts, or the improved understanding of the performance of the waste disposal facility in combination with the features of the site on which it is located alter the conclusions or the conceptual model(s) of the existing performance assessment or composite analysis.

(b) A determination of the continued adequacy of the performance assessment and composite analysis shall be
Facility Compliance Information

See P. above.

See P. above.

See P. above.

See P. above. 
Table 1. (continued).

Facility Name: CFA-622 High-Temperature Materials Laboratory

\begin{tabular}{|l|l|}
\hline \multicolumn{1}{|c|}{ Chapter IV, LLW Requirements } & Facility Compliance Information \\
\hline $\begin{array}{l}\text { made on an annual basis, and shall consider the results of } \\
\text { data collection and analysis from research, field studies, } \\
\text { and monitoring. }\end{array}$ & \\
\hline
\end{tabular}

(c) Annual summaries of low-level waste disposal operations shall be prepared with respect to the conclusions and recommendations of the performance assessment and composite analysis and a determination of the need to revise the performance assessment or composite analysis.

(5) Disposal Authorization. A disposal authorization See P. above. statement shall be obtained prior to construction of a new low-level waste disposal facility. Field Elements with existing low-level waste disposal facilities shall obtain a disposal authorization statement in accordance with the schedule in the Complex-Wide Low-Level Waste Management Program Plan. The disposal authorization statement shall be issued based on a review of the facility's performance assessment, composite analysis, performance assessment and composite analysis maintenance, preliminary closure plan, and preliminary monitoring plan. The disposal authorization statement shall specify the limits and conditions on construction, design, operations, and closure of the low-level waste facility based on these reviews. A disposal authorization statement is a part of the radioactive waste management basis for a disposal facility. Failure to obtain a disposal authorization statement by the implementation date of this Order shall result in shutdown of the disposal facility.

(6) Disposal Facility Operations. The disposal facility design and operation must be consistent with the disposal facility closure plan and lead to disposal facility closure that provides a reasonable expectation that performance objectives will be met. Low-level waste shall be disposed in such a manner that achieves the performance objectives stated in this Chapter, consistent with the disposal facility radiological performance assessment. Additional requirements include:

(a) Operating procedures shall be developed and implemented for low-level waste disposal facilities that protect the public, workers, and the environment; ensure the security of the facility; minimize subsidence during and after waste emplacement; achieve long-term stability and minimize the need for long-term active maintenance; and meet the requirements of the closure/post-closure plan.

(b) Permanent identification markers for disposal excavations and monitoring wells shall be emplaced.

(c) Low-level waste placement into disposal units shall

See P. above.

See P. above.

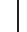

See P. above.

See P. above.

\begin{tabular}{|l|l|} 
& \\
\hline See P. above. \\
\hline See P. above.
\end{tabular}


Table 1. (continued).

Facility Name: CFA-622 High-Temperature Materials Laboratory

\begin{tabular}{|l|}
\hline \multicolumn{1}{|c|}{ Chapter IV, LLW Requirements } \\
\hline $\begin{array}{l}\text { minimize voids between waste containers. Voids within } \\
\text { disposal units shall be filled to the extent practical. } \\
\text { Uncontainerized bulk waste shall also be placed in a } \\
\text { manner that minimizes voids and subsidence. }\end{array}$ \\
\hline (d) Operations are to be conducted so that active waste
\end{tabular}
disposal operations will not have an adverse effect on any other disposal units.

(e) Operations shall include a process for tracking and documenting low-level waste placement in the facility by generator source.

(7) Alternate Requirements for Low-Level Waste Disposal Facility Design and Operation. Requirements other than those set forth in this Section for the design and operation of a low-level waste disposal facility may be approved on a specific basis if a reasonable expectation is demonstrated that the disposal performance objectives will be met.

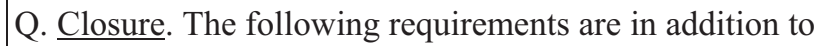
those in Chapter I of this Manual.

(1) Disposal Facility Closure Plans. A preliminary closure See Q. above. plan shall be developed and submitted to Headquarters for review with the performance assessment and composite analysis. The closure plan shall be updated following issuance of the disposal authorization statement to incorporate conditions specified in the disposal authorization statement. Closure plans shall:

(a) Be updated as required during the operational life of the facility.

(b) Include a description of how the disposal facility will be closed to achieve long-term stability and minimize the need for active maintenance following closure and to ensure compliance with the requirements of DOE 5400.5, Radiation Protection of the Public and the Environment.

(c) Include the total expected inventory of wastes to be disposed of at the facility over the operational life of the facility.

(2) Disposal Facility Closure. Closure of a disposal facility shall occur within a five-year period after it is filled to capacity, or after the facility is otherwise determined to be no longer needed.

See Q. above.

See Q. above.

See Q. above.

See Q. above. Facility Compliance Information

See P. above.

See P. above.

See P. above.

NA; this facility does not dispose of LLW.

See , (1)

See Q. above.


Table 1. (continued).

\begin{tabular}{|c|c|}
\hline \multicolumn{2}{|c|}{ Facility Name: CFA-622 High-Temperature Materials Laboratory } \\
\hline Chapter IV, LLW Requirements & Facility Compliance Information \\
\hline $\begin{array}{l}\text { (a) Prior to facility closure, the final inventory of the low- } \\
\text { level waste disposed in the facility shall be prepared and } \\
\text { incorporated in the performance assessment and } \\
\text { composite analysis which shall be updated to support the } \\
\text { closure of the facility. }\end{array}$ & See Q. above. \\
\hline $\begin{array}{l}\text { (b) A final closure plan shall be prepared based on the } \\
\text { final inventory of waste disposed in the facility, the plan } \\
\text { implemented, and the updated performance assessment } \\
\text { and composite analysis prepared in support of the facility } \\
\text { closure. }\end{array}$ & See Q. above. \\
\hline $\begin{array}{l}\text { (c) Institutional control measures shall be integrated into } \\
\text { land use and stewardship plans and programs, and shall } \\
\text { continue until the facility can be released pursuant to } \\
\text { DOE 5400.5, Radiation Protection of the Public and the } \\
\text { Environment. }\end{array}$ & See Q. above. \\
\hline $\begin{array}{l}\text { (d) The location and use of the facility shall be filed with } \\
\text { the local authorities responsible for land use and zoning. }\end{array}$ & See Q. above. \\
\hline $\begin{array}{l}\text { R. Monitoring. The following requirements are in addition } \\
\text { to those in Chapter I of this Manual [DOE M 435.1-1 } \\
\text { §I.1.E(7)]. }\end{array}$ & $\begin{array}{l}\text { DOE Manual 435.1-1 §I.1.E(7) applies to field element } \\
\text { managers. }\end{array}$ \\
\hline $\begin{array}{l}\text { (1) All Waste Facilities. Parameters that shall be sampled } \\
\text { or monitored, at a minimum, include: temperature, } \\
\text { pressure (for closed systems), radioactivity in ventilation } \\
\text { exhaust and liquid effluent streams, and flammable or } \\
\text { explosive mixtures of gases. Facility monitoring programs } \\
\text { shall include verification that passive and active control } \\
\text { systems have not failed. }\end{array}$ & $\begin{array}{l}\text { Monitoring requirements at INL radioactive waste } \\
\text { management facilities are tailored for the specific } \\
\text { facility to enable timely indication of developing } \\
\text { problems. Existing radiological control procedures and } \\
\text { assessments are followed/completed to monitor waste } \\
\text { facilities. }\end{array}$ \\
\hline $\begin{array}{l}\text { From DOE G 435.1-1 Chapter IV: The minimum } \\
\text { parameters specified in the requirement were selected } \\
\text { based on their potential significance for anticipating and } \\
\text { identifying undesirable conditions at low-level waste } \\
\text { management facilities. Each facility's radioactive waste } \\
\text { management basis should include an evaluation of the } \\
\text { applicability and significance of the minimum parameters. } \\
\text { This evaluation also needs to consider additional } \\
\text { parameters to be sampled or monitored to ensure the } \\
\text { protection of the public health, the environment, and the } \\
\text { workers. If a minimum parameter specified in the } \\
\text { requirement is deemed to be not applicable in any way to } \\
\text { the active operation of that facility, then that justification } \\
\text { should be included in the radioactive waste management } \\
\text { basis and when approved constitutes an exemption to the } \\
\text { manual. }\end{array}$ & $\begin{array}{l}\text { LRD-15001 and MCP-139 specify methods and } \\
\text { frequency of radiological control surveys of all } \\
\text { radiological areas. MCP-139 specifies the use of } \\
\text { Form } 441 . \text { A34. This form is referred to as the "routine } \\
\text { sheet" and is to be used by facility radiological control } \\
\text { foremen to list radiological areas that are to be } \\
\text { surveyed, the survey periods, and methods. }\end{array}$ \\
\hline $\begin{array}{l}\text { Verification activities are part of the radioactive waste } \\
\text { management basis as a condition for operation and } \\
\text { documented appropriately. }\end{array}$ & \\
\hline Compliance with this requirement is demonstrated if & \\
\hline
\end{tabular}


Table 1. (continued).

Facility Name: CFA-622 High-Temperature Materials Laboratory

\begin{tabular}{|c|c|}
\hline Chapter IV, LLW Requirements & Facility Compliance Information \\
\hline $\begin{array}{l}\text { monitoring or sampling for the stated parameters is } \\
\text { performed for all facilities with a precision, accuracy, and } \\
\text { frequency consistent with timely identification of } \\
\text { developing problems and a justification exists in the } \\
\text { approved radioactive waste management basis for those } \\
\text { specified parameters which are not monitored or sampled. }\end{array}$ & \\
\hline $\begin{array}{l}\text { (2) Liquid Waste Storage Facilities. For facilities storing } \\
\text { liquid low-level waste, the following shall also be } \\
\text { monitored: liquid level and/or waste volume, and } \\
\text { significant waste chemistry parameters. }\end{array}$ & NA; liquid LLW is not stored in this facility. \\
\hline $\begin{array}{l}\text { (3) Disposal Facilities. A preliminary monitoring plan for } \\
\text { a low-level waste disposal facility shall be prepared and } \\
\text { submitted to Headquarters for review with the } \\
\text { performance assessment and composite analysis. The } \\
\text { monitoring plan shall be updated within one year } \\
\text { following issuance of the disposal authorization statement } \\
\text { to incorporate and implement conditions specified in the } \\
\text { disposal authorization statement. }\end{array}$ & NA; this facility does not dispose of LLW. \\
\hline $\begin{array}{l}\text { (a) The site-specific performance assessment and } \\
\text { composite analysis shall be used to determine the media, } \\
\text { locations, radionuclides, and other substances to be } \\
\text { monitored. }\end{array}$ & See (3) above. \\
\hline $\begin{array}{l}\text { (b) The environmental monitoring program shall be } \\
\text { designed to include measuring and evaluating releases, } \\
\text { migration of radionuclides, disposal unit subsidence, and } \\
\text { changes in disposal facility and disposal site parameters } \\
\text { which may affect long-term performance. }\end{array}$ & See (3) above. \\
\hline $\begin{array}{l}\text { (c) The environmental monitoring programs shall be } \\
\text { capable of detecting changing trends in performance to } \\
\text { allow application of any necessary corrective action prior } \\
\text { to exceeding the performance objectives in this Chapter. }\end{array}$ & See (3) above. \\
\hline
\end{tabular}

\subsection{CFA-625, Analytical Laboratory}

1. Facility description: Operations in the CFA-625 laboratory involve environmental analyses of soils, water, and other samples, some of which may be radioactive. Operations also involve Radioactive Measurements Laboratory activities in support of the ATR Complex. The environmental analyses performed in CFA-625 use chemicals and produce some chemically and radioactively contaminated materials. Two particular processes currently using these chemicals are transuranic waste gas analysis and bioassay analysis of specimens. There are over a dozen laboratory and related support operations conducted in the facility, as well as outdoor compressed gas cylinder handling and storage operations along the facility's outside walls.

CFA-625 was constructed offsite as 19 separate modules that were shipped in 1989 and assembled at INL.

2. Hazard category: LTHC3 radiological 
3. Radioactive waste managed at this facility: Routine contact-handled LLW and mixed LLW is generated and staged at this facility.

4. RWMB documents/programs:

a) Safety basis/hazard analysis:

- ECAR-521, "Hazard Categorization Document for the CFA-625 Laboratory"

b) Laboratory-wide:

- Form 435.39, "Waste Determination and Disposition Form (WDDF)"

- Form 435.42, "Radioactive Waste Inventory Sheet"

- Form 441.A34, "INL Radiological Control Required Surveys"

- LI-435, "Waste Management Routine Field Activities"

- LRD-15001, "Radiological Control Manual"

- LWP-8000, "Environmental Instructions for Facilities, Processes, Materials and Equipment"

- LWP-13840, "Management of Issues, Observations, and Noteworthy Practices"

- LWP-14002, "Timeout and Stop Work Authority"

- LWP-15011, "Radioactive Material Areas and Radioactive Storage Areas"

- LWP-17000, "Waste Management"

- MCP-139, "Radiological Surveys"

- MCP-17000, "Waste Generator Services Waste Management"

- MCP-17410, "Management of Waste Storage Areas"

- MCP-17500, "Waste Generator Services Certification of Waste Shipments to the Nevada Test Site"

- PDD-17000, "Waste Management Program"

- PLN-114, "INL Emergency Plan/RCRA Contingency Plan"

- PLN-522, "Quality Assurance Program Plan for the Waste Management/Waste Certification Program"

c) Facility-specific:

- 1390-08-RTC/CFA, "Routine Radioanalytical Chemistry"

- 1428-08-CFA, "Elemental Analysis and Analytical Chemistry at CFA"

- 1530-09-CFA, "Solvent Extraction Batch Contacts at CFA"

- 1531-09-CFA, "Utility of Unusual Oxidation States of Americium for Separations at CFA."

LLW is managed at this facility. Table 2 presents the facility compliance information for Chapter IV, "Low-level Waste Requirements."

Table 2. CFA-625, Analytical Laboratory, DOE Manual 435.1-1 low-level waste requirements and facility compliance information.

\begin{tabular}{|c|l|}
\hline \multicolumn{2}{|c|}{ Facility Name: CFA-625, Analytical Laboratory } \\
\hline \multicolumn{1}{|c|}{ Chapter IV. Low-Level Waste Requirements } & \multicolumn{1}{|c|}{ Facility Compliance Information } \\
\hline $\begin{array}{l}\text { A. Definition of Low-Level Waste. Low-level } \\
\text { radioactive waste is radioactive waste that is not high- } \\
\text { level radioactive waste, spent nuclear fuel, transuranic } \\
\text { waste, byproduct material (as defined in section 11e.(2) }\end{array}$ & $\begin{array}{l}\text { This requirement provides the criteria for determining } \\
\text { which DOE radioactive waste is to be managed as LLW } \\
\text { in accordance with DOE Manual 435.1-1, Chapter IV. }\end{array}$ \\
\hline
\end{tabular}


Table 2. (continued).

\section{Facility Name: CFA-625, Analytical Laboratory}

Chapter IV. Low-Level Waste Requirements

of the Atomic Energy Act of 1954, as amended), or naturally occurring radioactive material.

(From DOE G 435.1-1 Chapter IV: Low-level radioactive waste is defined by what it is not. The guidance on definitions in Chapters II and III should be consulted first for making a determination on how to properly manage a suspect waste stream.)

B. Management of Specific Wastes. The following provide for management of specific wastes as low-level waste in accordance with the requirements in this Chapter:

(1) Mixed Low-Level Waste. Low-level waste determined to contain both source, special nuclear, or byproduct material subject to the Atomic Energy Act of 1954, as amended, and a hazardous component subject to the Resource Conservation and Recovery Act (RCRA), as amended, shall be managed in accordance with the requirements of RCRA and DOE O 435.1, Radioactive Waste Management, and this Manual.

(2) TSCA-Regulated Waste. Low-level waste containing polychlorinated biphenyls, asbestos, or other such regulated toxic components shall be managed in accordance with requirements derived from the Toxic Substances Control Act, as amended, DOE O 435.1, Radioactive Waste Management, and this Manual.

(3) Accelerator-Produced Waste. Radioactive waste produced as a result of operations of DOE accelerators is low-level waste and shall be managed in accordance with DOE O 435.1, Radioactive Waste Management, and this Manual, and all applicable Federal or State requirements.

(4) 11e.(2) and Naturally Occurring Radioactive Material. Small quantities of 11e.(2) byproduct material and naturally occurring radioactive material may be managed as low-level waste provided they can be managed to meet the requirements for low-level waste disposal in Section IV.P of this Manual.

\section{Complex-Wide Low-Level Waste Management} Program. A complex-wide program and plan shall be developed as described under Responsibilities, 2.B and 2.D, in Chapter I of this Manual.

D. Radioactive Waste Management Basis. Low-level waste facilities, operations, and activities shall have a radioactive waste management basis consisting of physical and administrative controls to ensure the protection of workers, the public, and the environment. The following specific waste management controls shall be part of the radioactive waste management basis:

\section{Facility Compliance Information}

Radioactive waste managed at this facility under the requirements of this chapter is not managed under the requirements of DOE Manual 435.1-1 Chapter II or Chapter III.

See (1), (2), (3), and (4) below.

This facility manages mixed LLW in SAAs. Management of SAAs is addressed in MCP-17410 and overall management of mixed waste is addressed in MCP-17000.

NA; this facility does not manage TSCA-regulated waste.

NA; this facility does not manage accelerator-produced waste.

NA; this facility does not manage naturally occurring radioactive material.

Not a facility-specific requirement. DOE Manual 435.1-1 $\S$ I.2.B and §I.2.D apply to the Assistant Secretary for Environmental Management and the Deputy Assistant Secretary for Waste Management, respectively.

The RWMB provides the regulatory framework for management of radioactive waste at INL. It specifically identifies facility management and implementing documents for the generation, storage, treatment, and disposal of radiological waste. 
Table 2. (continued).

Facility Name: CFA-625, Analytical Laboratory

Chapter IV. Low-Level Waste Requirements

(1) Generators. The waste certification program.

From DOE G 435.1-1 Chapter IV: For a facility that generates low-level waste, the radioactive waste management basis is to include the program for certifying that waste meets the waste acceptance requirements of the facility(ies) to which the waste will be sent.

(2) Treatment Facilities certification program. The waste acceptance requirements and the waste [sic]

From DOE G 435.1-1 Chapter IV: Facilities that store or treat low-level waste are to have approved waste acceptance requirements (see DOE M 435.1-1, Section IV.G) prior to the issuance of a radioactive waste management basis.

A facility that stores or treats waste also is generally expected to have a waste certification program. Waste from these facilities will have to be certified as meeting the waste acceptance requirements of the facility to which it will be transferred, and the facilities have the potential for generating radioactive waste (e.g., secondary processing streams from treatment, monitoring and sampling, radioactive release cleanup). Consequently, storage and treatment facilities should also have an approved waste certification program as part of their radioactive waste management basis.

As part of the radioactive waste management basis, site personnel needs to implement a system or process for tracking the waste inventory at a storage, treatment, or disposal facility.

(3) Storage Facilities. The waste acceptance requirements and the waste certification program.

From DOE G 435.1-1 Chapter IV: Facilities that store or treat low-level waste are to have approved waste acceptance requirements (see DOE M 435.1-1, Section IV.G) prior to the issuance of a radioactive waste management basis.

A facility that stores or treats waste also is generally expected to have a waste certification program. Waste from these facilities will have to be certified as meeting the waste acceptance requirements of the facility to which it will be transferred, and the facilities have the potential for generating radioactive waste (e.g., secondary processing streams from treatment, monitoring and sampling, radioactive release cleanup). Consequently, storage and treatment facilities should also have an approved waste certification program as part of their radioactive waste management basis.

\section{Facility Compliance Information}

See J. below for waste certification program requirements.

ECAR-521 establishes this laboratory facility as an LTHC3 radiological facility.

NA; waste is not treated at this facility.

Containerized elementary neutralization is performed at this facility as provided by LWP-8000. As stated in $\S 4.118$, elementary neutralization of corrosive hazardous waste may take place at any location at which the waste is generated or stored, and neither a generator treatment plan nor a permit is required. Solidification of liquid LLW for the purpose of staging (not for treating the radioactive constituents) also may be performed. Therefore, this facility is not considered to be a treatment facility.
NA; this facility stages waste in accordance with N.(7) to facilitate treatment or disposal. 
Table 2. (continued).

\begin{tabular}{|c|c|}
\hline \multicolumn{2}{|c|}{ Facility Name: CFA-625, Analytical Laboratory } \\
\hline Chapter IV. Low-Level Waste Requirements & Facility Compliance Information \\
\hline $\begin{array}{l}\text { As part of the radioactive waste management basis, site } \\
\text { personnel needs to implement a system or process for } \\
\text { tracking the waste inventory at a storage, treatment, or } \\
\text { disposal facility. }\end{array}$ & \\
\hline $\begin{array}{l}\text { (4) Disposal Facilities. The performance assessment, } \\
\text { composite analysis, disposal authorization statement, } \\
\text { closure plan, waste acceptance requirements, and } \\
\text { monitoring plan. }\end{array}$ & NA; this facility is not a disposal facility. \\
\hline $\begin{array}{l}\text { E. Contingency Actions. The following requirements are } \\
\text { in addition to those in Chapter I of this Manual [DOE M } \\
435.1-1 \text { §I.1.E(5)]. }\end{array}$ & $\begin{array}{l}\text { DOE Manual 435.1-1 } \S \text { I.1.E }(5) \text { addresses the sitewide } \\
\text { emergency management system. The INL plan is } \\
\text { provided in PLN-114. }\end{array}$ \\
\hline $\begin{array}{l}\text { (1) Contingency Storage. For off-normal or emergency } \\
\text { situations involving high activity or high hazard liquid } \\
\text { low-level waste storage or treatment, spare capacity with } \\
\text { adequate capabilities shall be maintained to receive the } \\
\text { largest volume of liquid contained in any one storage } \\
\text { tank or treatment facility. Tanks or other facilities that } \\
\text { are designated low-level waste contingency storage shall } \\
\text { be maintained in an operational condition when waste is } \\
\text { present and shall meet the requirements of DOE O 435.1, } \\
\text { Radioactive Waste Management, and this Manual. }\end{array}$ & NA; this facility does not store liquid LLW. \\
\hline $\begin{array}{l}\text { From DOE G 435.1-1 Chapter IV: Compliance with } \\
\text { these requirements is demonstrated if adequate spare } \\
\text { capacity and transfer equipment exists for emergency } \\
\text { transfers of all high activity and high hazard liquid low- } \\
\text { level waste. In addition, the capability to perform } \\
\text { emergency transfers is demonstrated by having waste } \\
\text { transfer routings identified, operational procedures to } \\
\text { direct transfers, staff trained to the procedures, and } \\
\text { records showing that the spare capacity and transfer } \\
\text { capability are kept in operating condition. }\end{array}$ & \\
\hline $\begin{array}{l}\text { (2) Transfer Equipment. Pipelines and auxiliary facilities } \\
\text { necessary for the transfer of high activity or high hazard } \\
\text { liquid low-level waste to contingency storage shall be } \\
\text { maintained in an operational condition when waste is } \\
\text { present and shall meet the requirements of DOE O 435.1, } \\
\text { Radioactive Waste Management, and this Manual. }\end{array}$ & NA; this facility does not store or treat liquid LLW. \\
\hline $\begin{array}{l}\text { From DOE G } 435.1-1 \text { Chapter IV: Compliance with } \\
\text { these requirements is demonstrated if adequate spare } \\
\text { capacity and transfer equipment exists for emergency } \\
\text { transfers of all high activity and high hazard liquid low- } \\
\text { level waste. In addition, the capability to perform } \\
\text { emergency transfers is demonstrated by having waste } \\
\text { transfer routings identified, operational procedures to } \\
\text { direct transfers, staff trained to the procedures, and } \\
\text { records showing that the spare capacity and transfer } \\
\text { capability are kept in operating condition. }\end{array}$ & \\
\hline
\end{tabular}


Table 2. (continued).

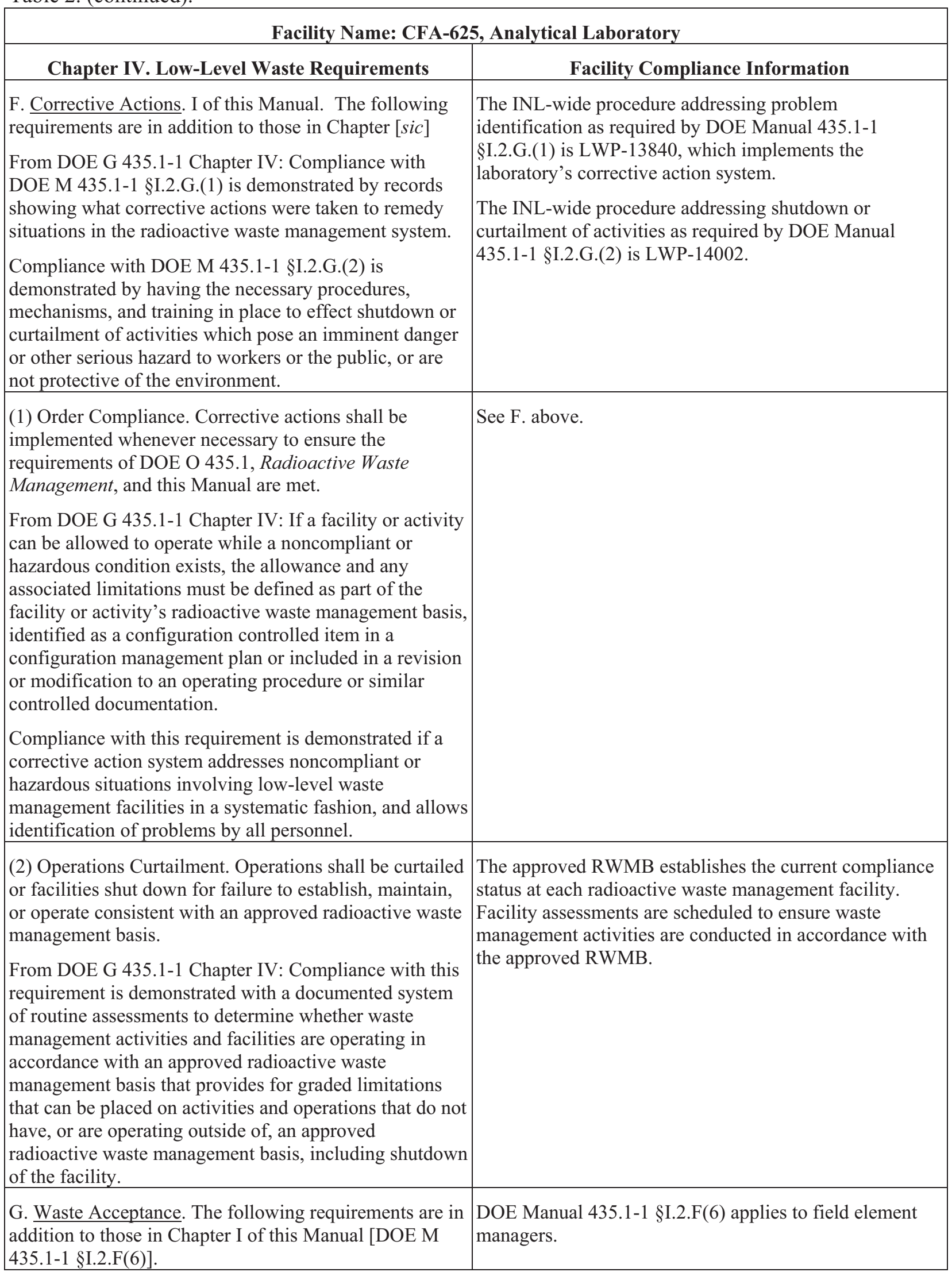


Table 2. (continued).

Facility Name: CFA-625, Analytical Laboratory

\begin{tabular}{|c|c|}
\hline Chapter IV. Low-Level Waste Requirements & Facility Compliance Information \\
\hline $\begin{array}{l}\text { (1) Technical and Administrative. Waste acceptance } \\
\text { requirements for all low-level waste storage, treatment, } \\
\text { or disposal facilities, operations, and activities shall } \\
\text { specify, at a minimum, the following: }\end{array}$ & $\begin{array}{l}\text { NA; this facility does not accept LLW from other } \\
\text { facilities. }\end{array}$ \\
\hline $\begin{array}{l}\text { From DOE G 435.1-1 Chapter IV: Compliance with } \\
\text { these waste acceptance requirements is demonstrated if } \\
\text { they are documented, contain clear and precise criteria } \\
\text { specifying the radionuclide limits in the form of contents } \\
\text { or concentrations that can be accepted, the limitations } \\
\text { and prohibitions on waste forms and packages that can } \\
\text { be received, and the limits, prohibitions, or instructions } \\
\text { concerning any other technical information so that the } \\
\text { waste is compatible with the safety basis of the facility, } \\
\text { and which will result in acceptable waste at subsequent } \\
\text { steps in managing the low-level waste. }\end{array}$ & \\
\hline $\begin{array}{l}\text { (a) Allowable activities and/or concentrations of specific } \\
\text { radionuclides. }\end{array}$ & See (1) above. \\
\hline $\begin{array}{l}\text { (b) Acceptable waste form and/or container requirements } \\
\text { that ensure the chemical and physical stability of waste } \\
\text { under conditions that might be encountered during } \\
\text { transportation, storage, treatment, or disposal. }\end{array}$ & See (1) above. \\
\hline $\begin{array}{l}\text { (c) Restrictions or prohibitions on waste, materials, or } \\
\text { containers that may adversely affect waste handlers or } \\
\text { compromise facility or waste container performance. }\end{array}$ & See (1) above. \\
\hline $\begin{array}{l}\text { (d) The following are additional waste acceptance } \\
\text { requirements that shall be specified in low-level waste } \\
\text { disposal facility waste acceptance requirements: }\end{array}$ & See (1) above. \\
\hline $\begin{array}{l}1 \text { Low-level waste must contribute to and not detract } \\
\text { from achieving long-term stability of the facility, } \\
\text { minimizing the need for long-term active maintenance, } \\
\text { minimizing subsidence, and minimizing contact of water } \\
\text { with waste. Void spaces within the waste and, if } \\
\text { containers are used, between the waste and its container } \\
\text { shall be reduced to the extent practical. }\end{array}$ & See (1) above. \\
\hline $\begin{array}{l}2 \text { Liquid low-level waste or low-level waste containing } \\
\text { free liquid must be converted into a form that contains as } \\
\text { little freestanding liquid as is reasonably achievable, but } \\
\text { in no case shall the liquid exceed } 1 \text { percent of the waste } \\
\text { volume when the low-level waste is in a disposal } \\
\text { container, or } 0.5 \text { percent of the waste volume after it is } \\
\text { processed to a stable form. }\end{array}$ & See (1) above. \\
\hline $\begin{array}{l}3 \text { Low-level waste must not be readily capable of } \\
\text { detonation or of explosive decomposition or reaction at } \\
\text { anticipated pressures and temperatures, or of explosive } \\
\text { reaction with water. Pyrophoric materials contained in } \\
\text { waste shall be treated, prepared, and packaged to be } \\
\text { nonflammable. }\end{array}$ & See (1) above. \\
\hline
\end{tabular}


Table 2. (continued).

\begin{tabular}{|c|c|}
\hline \multicolumn{2}{|c|}{ Facility Name: CFA-625, Analytical Laboratory } \\
\hline Chapter IV. Low-Level Waste Requirements & Facility Compliance Information \\
\hline $\begin{array}{l}4 \text { Low-level waste must not contain, or be capable of } \\
\text { generating by radiolysis or biodegradation, quantities of } \\
\text { toxic gases, vapors, or fumes harmful to the public or } \\
\text { workers or disposal facility personnel, or harmful to the } \\
\text { long-term structural stability of the disposal site. }\end{array}$ & See (1) above. \\
\hline $\begin{array}{l}5 \text { Low-level waste in a gaseous form must be packaged } \\
\text { such that the pressure does not exceed } 1.5 \text { atmospheres } \\
\text { absolute at } 20 \mathrm{C} \text {. [sic] }\end{array}$ & See (1) above. \\
\hline $\begin{array}{l}\text { (e) The basis, procedures, and levels of authority } \\
\text { required for granting exceptions to the waste acceptance } \\
\text { requirements, which shall be contained in each facility's } \\
\text { waste acceptance documentation. Each exception request } \\
\text { shall be documented, including its disposition as } \\
\text { approved or not approved. }\end{array}$ & See (1) above. \\
\hline $\begin{array}{l}\text { From DOE G 435.1-1 Chapter IV: Waste acceptance } \\
\text { requirements are acceptable if they are documented and } \\
\text { contain a clear description of the procedure and bases for } \\
\text { obtaining an exception or deviation to the acceptance } \\
\text { criteria for low-level waste to be received at the facility. }\end{array}$ & \\
\hline $\begin{array}{l}\text { (2) Evaluation and Acceptance. The receiving facility } \\
\text { shall evaluate waste for acceptance, including } \\
\text { confirmation that the technical and administrative } \\
\text { requirements have been met. A process for the } \\
\text { disposition of non-conforming wastes shall be } \\
\text { established. }\end{array}$ & See (1) above. \\
\hline $\begin{array}{l}\text { From DOE G 435.1-1 Chapter IV: Compliance with the } \\
\text { waste acceptance requirements for a low-level waste } \\
\text { management facility is demonstrated if they include a } \\
\text { process for evaluation and acceptance of incoming waste } \\
\text { to ensure the acceptance criteria of the facility receiving } \\
\text { the waste are met that includes one of or a combination } \\
\text { of: (1) testing, sampling, and analysis of representative } \\
\text { samples of waste upon receipt; (2) testing, sampling, and } \\
\text { analysis of split samples of waste taken at the generator } \\
\text { site; (3) evaluation of testing, sampling, and analysis of } \\
\text { data provided by the generator, or (4) audits, reviews, } \\
\text { surveillance, or observations of generator waste } \\
\text { certification programs and characterization activities. } \\
\text { Additionally, acceptable waste acceptance requirements } \\
\text { for a storage, treatment or disposal facility will have } \\
\text { documented procedures and actions to be taken if a } \\
\text { waste that does not conform to the waste acceptance } \\
\text { criteria is received at the facility. }\end{array}$ & \\
\hline $\begin{array}{l}\text { H. Waste Generation Planning. The following } \\
\text { requirements are in addition to those in Chapter I of this } \\
\text { Manual [DOE M 435.1-1 §I.2.F(7)]. }\end{array}$ & $\begin{array}{l}\text { DOE Manual 435.1-1 §I.2.F(7) applies to field element } \\
\text { managers. }\end{array}$ \\
\hline (1) Life-Cycle Planning. Prior to waste gener & PDD-17000 and LWP-17000 provide direction to the \\
\hline
\end{tabular}


Table 2. (continued).

\section{Facility Name: CFA-625, Analytical Laboratory}

Chapter IV. Low-Level Waste Requirements

planning shall be performed to address the entire life cycle for all low-level waste streams.

From DOE G 435.1-1 Chapter IV: Compliance with this planning requirement is demonstrated by the individual sites establishing a process for evaluating the life-cycle of low-level waste prior to its generation, including the identification of low-level wastes with no path to disposal and appropriate records justifying the newly generated low-level waste stream(s), and site personnel possessing planning information showing the location(s) where low-level waste will be stored, treated, and/or disposed along with a confirmation that the personnel managing the facilities agree that the low-level waste may be managed at those facilities.

\section{Facility Compliance Information}

waste generators for waste generation planning to address the entire life cycle.

Form 435.39 and Form 435.42 are used to identify radioactive LLW.

(2) Waste with No Identified Path to Disposal. Low-level This facility is not generating radioactive waste that does waste streams with no identified path to disposal shall be not have an identified path to disposal. generated only in accordance with approved conditions which, at a minimum, shall address:

(a) Programmatic need to generate the waste; See (2) above.

(b) Characteristics and issues preventing the disposal of See (2) above. the waste;

(c) Safe storage of the waste until disposal can be achieved; and

(d) Activities and plans for achieving final disposal of the waste.

I. Waste Characterization. Low-level waste shall be characterized using direct or indirect methods, and the characterization documented in sufficient detail to ensure safe management and compliance with the waste acceptance requirements of the facility receiving the waste.

From DOE G 435.1-1 Chapter IV: Compliance with this requirement is demonstrated by a program for documenting and the existence of records that document the process for acquiring and verifying the validity of low-level waste characterization data acquired through the use of direct or indirect methods.

See (2) above.

See (2) above.

MCP-17000 $§ 4$ specifies the requirements for preparing an IWTS profile that captures waste characterization information.

Individual laboratory projects have project-specific laboratory instructions that address management of LLW and mixed LLW in accordance with INL Manual 17 waste management requirements.

Laboratory Instruction 1390-08-RTC/CFA, Table 2.03 provides very general characterization information regarding the waste types and volumes generated subsequent to this specific process. The table also provides the method of disposal.

Laboratory Instruction 1428-08-CFA, Table 2.03 provides very general characterization information regarding the waste types and volumes generated subsequent to routine laboratory operations. The table also provides the method of disposal.

Laboratory Instruction 1530-09-CFA, Table 2.03 provides very general characterization information regarding the waste types and volumes generated subsequent to routine laboratory operations. The table also provides the method 
Table 2. (continued).

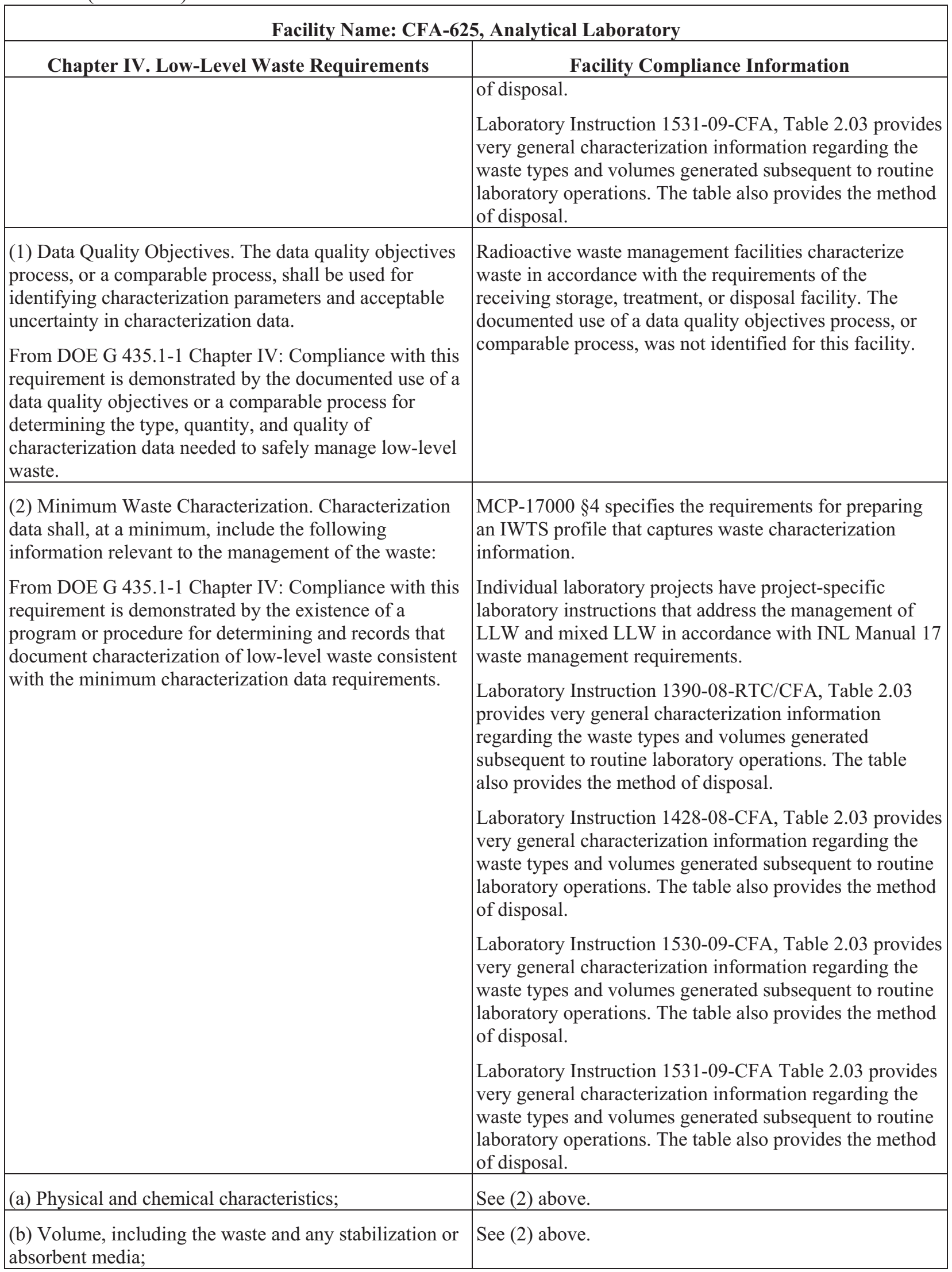


Table 2. (continued).

\begin{tabular}{|c|c|}
\hline \multicolumn{2}{|c|}{ Facility Name: CFA-625, Analytical Laboratory } \\
\hline Chapter IV. Low-Level Waste Requirements & Facility Compliance Information \\
\hline (c) Weight of the container and contents; & See (2) above. \\
\hline $\begin{array}{l}\text { (d) Identities, activities, and concentrations of major } \\
\text { radionuclides; }\end{array}$ & See (2) above. \\
\hline (e) Characterization date; & See (2) above. \\
\hline (f) Generating source; and & See (2) above. \\
\hline $\begin{array}{l}\text { (g) Any other information which may be needed to } \\
\text { prepare and maintain the disposal facility performance } \\
\text { assessment, or demonstrate compliance with applicable } \\
\text { performance objectives. }\end{array}$ & See (2) above. \\
\hline $\begin{array}{l}\text { J. Waste Certification. A waste certification program } \\
\text { shall be developed, documented, and implemented to } \\
\text { ensure that the waste acceptance requirements of } \\
\text { facilities receiving low-level waste for storage, } \\
\text { treatment, and disposal are met. }\end{array}$ & $\begin{array}{l}\text { MCP-17000 } \S 4 \text { specifies the requirements for preparing } \\
\text { an IWTS profile that captures waste certification } \\
\text { information. } \\
\text { MCP-17500 provides the Waste Generator Services waste } \\
\text { certification program for LLW to be shipped to NNSS. }\end{array}$ \\
\hline $\begin{array}{l}\text { From DOE G } 435.1-1 \text { Chapter IV: Compliance with the } \\
\text { development and documentation portion of the } \\
\text { certification requirement is demonstrated by a waste } \\
\text { certification plan that identifies the organizations } \\
\text { involved, assigns responsibilities for implementing the }\end{array}$ & $\begin{array}{l}\text { Container procurement is addressed in MCP-17000 } \$ 4.6 . \\
\text { Waste certification is performed and tracked using IWTS. } \\
\text { Documentation of the IWTS program is only available } \\
\text { electronically. }\end{array}$ \\
\hline $\begin{array}{l}\text { management, and procedures to be used by the program. } \\
\text { Acceptable performance for implementing the program } \\
\text { is demonstrated when appropriate personnel are trained } \\
\text { and follow the procedures that govern their part of the } \\
\text { waste certification. Additionally, acceptable performance } \\
\text { is demonstrated if the waste certification plan and } \\
\text { procedures are current and controlled in accordance with } \\
\text { a document controls program, and records related to } \\
\text { certification (e.g., certification statements, training } \\
\text { records, procurement records, characterization records, } \\
\text { container records) are generated and managed in } \\
\text { accordance with the established site program. }\end{array}$ & $\begin{array}{l}\text { PLN-522 requires waste technical specialists and waste } \\
\text { disposition specialists to complete the appropriate } \\
\text { training/qualification before being granted approval } \\
\text { authority for profiles within the IWTS Program. The } \\
\text { waste certification official, alternate waste certification } \\
\text { official, and NNSS packaging certifiers must complete the } \\
\text { appropriate training/qualifications to disposition waste to } \\
\text { NNSS. }\end{array}$ \\
\hline $\begin{array}{l}\text { (1) Certification Program. The waste certification } \\
\text { program shall designate the officials who have the } \\
\text { authority to certify and release waste for shipment; and } \\
\text { specify what documentation is required for waste } \\
\text { generation, characterization, shipment, and certification. } \\
\text { The program shall provide requirements for auditability, } \\
\text { retrievability, and storage of required documentation and } \\
\text { specify the records retention period. }\end{array}$ & See J. above. \\
\hline $\begin{array}{l}\text { From DOE G 435.1-1 Chapter IV: Compliance with this } \\
\text { requirement is demonstrated by a program or procedure } \\
\text { for record keeping and records showing that low-level } \\
\text { waste is certified as having met the waste acceptance } \\
\text { criteria of the facility to which it was transferred and that } \\
\text { the certification statement is supported by additional }\end{array}$ & \\
\hline
\end{tabular}


Table 2. (continued).

Facility Name: CFA-625, Analytical Laboratory

\begin{tabular}{|c|c|}
\hline \multicolumn{2}{|c|}{ Facility Name: CFA-625, Analytical Laboratory } \\
\hline Chapter IV. Low-Level Waste Requirements & Facility Compliance Information \\
\hline $\begin{array}{l}\text { records regarding the waste source, characterization, and } \\
\text { container. }\end{array}$ & \\
\hline $\begin{array}{l}\text { (2) Certification before Transfer. Low-level waste shall } \\
\text { be certified as meeting waste acceptance requirements } \\
\text { before it is transferred to the facility receiving the waste. }\end{array}$ & See J. above. \\
\hline $\begin{array}{l}\text { From DOE G } 435.1-1 \text { Chapter IV: Compliance with this } \\
\text { requirement is demonstrated by the presence of a } \\
\text { certification program which includes procedures } \\
\text { requiring a signed certification statement prior to the } \\
\text { release of waste for transfer, and by dated records } \\
\text { showing that waste was certified before being } \\
\text { transferred. }\end{array}$ & \\
\hline $\begin{array}{l}\text { (3) Maintaining Certification. Low-level waste that has } \\
\text { been certified as meeting the waste acceptance } \\
\text { requirements for transfer to a storage, treatment, or } \\
\text { disposal facility shall be managed in a manner that } \\
\text { maintains its certification status. }\end{array}$ & See J. above. \\
\hline $\begin{array}{l}\text { From DOE G } 435.1-1 \text { Chapter IV: Compliance with this } \\
\text { requirement is demonstrated by a program or procedure } \\
\text { reflecting this requirement is present and site personnel } \\
\text { are able to show that the storage of low-level waste } \\
\text { containers is in a facility or manner where the containers } \\
\text { would not be damaged by normal weather events, and } \\
\text { cannot be accessed by unauthorized personnel. Further, } \\
\text { each container can be traced to its certification and the } \\
\text { information supporting that certification. }\end{array}$ & \\
\hline $\begin{array}{l}\text { K. Waste Transfer. A documented process shall be } \\
\text { established and implemented for transferring } \\
\text { responsibility for management of low-level waste and for }\end{array}$ & $\begin{array}{l}\text { MCP- } 17000 \text { specifies the requirements for preparing an } \\
\text { IWTS profile that captures waste certification data, } \\
\text { transfer information, and associated authorizations. }\end{array}$ \\
\hline $\begin{array}{l}\text { ensuring avallability of relevant data. The following } \\
\text { requirements are in addition to those in Chapter I of this } \\
\text { Manual. }\end{array}$ & $\begin{array}{l}\text { MCP- } 17500 \text { provides the Waste Generator Services } \\
\text { Waste Certification Program for LLW to be shipped to } \\
\text { NNSS. }\end{array}$ \\
\hline $\begin{array}{l}\text { From DOE G 435.1-1 Chapter IV: Compliance with this } \\
\text { requirement is demonstrated if facilities have procedures } \\
\text { for the receipt of waste and the transfer of waste, as } \\
\text { appropriate, which address the acquisition of waste and } \\
\text { container data and the transfer of ownership, } \\
\text { respectively. Further evidence of acceptable performance } \\
\text { is facility records showing that data on the waste } \\
\text { containers is available and accurate, and that documented } \\
\text { transfer of responsibility occurs. }\end{array}$ & \\
\hline $\begin{array}{l}\text { (1) Authorization. Low-level waste shall not be } \\
\text { transferred to a storage, treatment, or disposal facility } \\
\text { until personnel responsible for the facility receiving the } \\
\text { waste authorize the transfer. }\end{array}$ & See K. above. \\
\hline $\begin{array}{l}\text { From DOE G 435.1-1 Chapter IV: Compliance with this } \\
\text { requirement is demonstrated by sites having procedures }\end{array}$ & \\
\hline
\end{tabular}


Table 2. (continued).

\begin{tabular}{|c|c|}
\hline \multicolumn{2}{|c|}{ Facility Name: CFA-625, Analytical Laboratory } \\
\hline Chapter IV. Low-Level Waste Requirements & Facility Compliance Information \\
\hline $\begin{array}{l}\text { that require a confirmation of authorization before } \\
\text { releasing waste for transfer, and records showing that } \\
\text { transfers are made in accordance with written } \\
\text { authorizations. }\end{array}$ & \\
\hline $\begin{array}{l}\text { (2) Data. Waste characterization data, container } \\
\text { information, and generation, storage, treatment, and } \\
\text { transportation information for low-level waste shall be } \\
\text { transferred with or be traceable to the waste. }\end{array}$ & See K. above. \\
\hline $\begin{array}{l}\text { From DOE G 435.1-1 Chapter IV: Compliance with this } \\
\text { requirement is demonstrated if there are procedures } \\
\text { requiring that characterization and container data be } \\
\text { provided and maintained for each low-level waste } \\
\text { transfer and documented records of transfers show that } \\
\text { the information is being provided. }\end{array}$ & \\
\hline $\begin{array}{l}\text { L. Packaging and Transportation. The following } \\
\text { requirements are in addition to those in Chapter I of this } \\
\text { Manual [DOE M 435.1-1 §I.1.E(11)]. }\end{array}$ & $\begin{array}{l}\text { DOE Manual 435.1-1 §I.1.E(11) applies to field element } \\
\text { managers. }\end{array}$ \\
\hline (1) Packaging. If containers are used: & MCP-17000 $\S 4$ addresses packaging requirements. \\
\hline $\begin{array}{l}\text { From DOE G 435.1-1 Chapter IV: Compliance with the } \\
\text { packaging requirement is demonstrated by: (1) } \\
\text { procedures which document proper packaging protocols; } \\
\text { and (2) no trends of routine repackaging of low-level } \\
\text { waste that is packaged after issuance of DOE O } 435.1 \text {. } \\
\text { Successful performance of this requirement is also } \\
\text { demonstrated by a record of containers for which failure } \\
\text { has not routinely occurred under management } \\
\text { conditions. It is recognized that there may be failed } \\
\text { containers for waste previously placed in storage. For } \\
\text { those containers, the goal is to only have to repackage } \\
\text { the waste one time after it is retrieved and characterized. } \\
\text { Further, acceptable performance is demonstrated by } \\
\text { containers of waste having marking and labeling that } \\
\text { allows correlation with waste characterization data and } \\
\text { container information. }\end{array}$ & \\
\hline $\begin{array}{l}\text { (a) Low-level waste shall be packaged in a manner that } \\
\text { provides containment and protection for the duration of } \\
\text { the anticipated storage period and until disposal is } \\
\text { achieved or until the waste has been removed from the } \\
\text { container. }\end{array}$ & See (1) above. \\
\hline $\begin{array}{l}\text { (b) When waste is packaged, vents or other measures } \\
\text { shall be provided if the potential exists for pressurizing } \\
\text { or generating flammable or explosive concentrations of } \\
\text { gases within the waste container. }\end{array}$ & See (1) above. \\
\hline $\begin{array}{l}\text { (c) Containers of low-level waste shall be marked such } \\
\text { that their contents can be identified. }\end{array}$ & See (1) above. \\
\hline $\begin{array}{l}\text { (2) Transportation. To the extent practical, the volume of } \\
\text { waste and number of low-level waste shipments shall be }\end{array}$ & $\begin{array}{l}\text { NA; waste is not shipped from this facility to an offsite } \\
\text { facility for final disposition. }\end{array}$ \\
\hline
\end{tabular}


Table 2. (continued).

Facility Name: CFA-625, Analytical Laboratory

\begin{tabular}{|c|c|}
\hline Chapter IV. Low-Level Waste Requirements & Facility Compliance Information \\
\hline \multirow{2}{*}{\multicolumn{2}{|c|}{$\begin{array}{l}\text { minimized. } \\
\text { From DOE G } 435.1-1 \text { Chapter IV: Compliance with this } \\
\text { requirement can be demonstrated by a combination of } \\
\text { site procedures directing the efficient use of waste } \\
\text { container capacity and documentation showing that low- } \\
\text { level waste shipments are systematically planned and } \\
\text { optimized to the extent practical. }\end{array}$}} \\
\hline & \\
\hline $\begin{array}{l}\text { M. Site Evaluation and Facility Design. The following } \\
\text { requirements are in addition to those in Chapter I of this } \\
\text { Manual. }\end{array}$ & $\begin{array}{l}\text { NA; this requirement addresses new radioactive waste } \\
\text { management facilities. }\end{array}$ \\
\hline $\begin{array}{l}\text { (1) Site Evaluation. Proposed locations for low-level } \\
\text { waste facilities shall be evaluated to identify relevant } \\
\text { features that should be avoided or must be considered in } \\
\text { facility design and analyses. }\end{array}$ & See M. above. \\
\hline $\begin{array}{l}\text { (a) Each site proposed for a new low-level waste facility } \\
\text { or expansion of an existing low-level waste facility shall } \\
\text { be evaluated considering environmental characteristics, } \\
\text { geotechnical characteristics, and human activities, } \\
\text { including for a low-level waste disposal facility, the } \\
\text { capability of the site to demonstrate, at a minimum, } \\
\text { whether it is: }\end{array}$ & See M. above. \\
\hline $\begin{array}{l}1 \text { Located to accommodate the projected volume of } \\
\text { waste to be received; }\end{array}$ & See M. above. \\
\hline $\begin{array}{l}2 \text { Located in a flood plain, a tectonically active area, or } \\
\text { in the zone of water table fluctuation; and }\end{array}$ & See M. above. \\
\hline $\begin{array}{l}3 \text { Located where radionuclide migration pathways are } \\
\text { predictable and erosion and surface runoff can be } \\
\text { controlled. }\end{array}$ & See M. above. \\
\hline $\begin{array}{l}\text { (b) Proposed sites with environmental characteristics, } \\
\text { geotechnical characteristics, and human activities for } \\
\text { which adequate protection cannot be provided through } \\
\text { facility design shall be deemed unsuitable for the } \\
\text { location of the facility. }\end{array}$ & See M. above. \\
\hline $\begin{array}{l}\text { (c) Low-level waste disposal facilities shall be sited to } \\
\text { achieve long-term stability and to minimize, to the extent } \\
\text { practical, the need for active maintenance following final } \\
\text { closure. }\end{array}$ & See M. above. \\
\hline $\begin{array}{l}\text { (2) Low-Level Waste Treatment and Storage Facility } \\
\text { Design. The following facility requirements and general } \\
\text { design criteria, at a minimum, apply: }\end{array}$ & See M. above. \\
\hline $\begin{array}{l}\text { (a) Confinement. Low-level waste systems and } \\
\text { components shall be designed to maintain waste } \\
\text { confinement. }\end{array}$ & See M. above. \\
\hline (b) Ventilation. & See M. above. \\
\hline
\end{tabular}


Table 2. (continued).

\begin{tabular}{|c|c|}
\hline \multicolumn{2}{|c|}{ Facility Name: CFA-625, Analytical Laboratory } \\
\hline Chapter IV. Low-Level Waste Requirements & Facility Compliance Information \\
\hline $\begin{array}{l}1 \text { Design of low-level waste treatment and storage } \\
\text { facilities shall include ventilation, if applicable, through } \\
\text { an appropriate filtration system to maintain the release of } \\
\text { radioactive material in airborne effluents within the } \\
\text { requirements and guidelines specified in applicable } \\
\text { requirements. }\end{array}$ & See M. above. \\
\hline $\begin{array}{l}2 \text { When conditions exist for generating gases in } \\
\text { flammable or explosive concentrations, ventilation } \\
\text { systems or other measures shall be provided to keep the } \\
\text { gases in a non-flammable and nonexplosive condition. } \\
\text { Where concentrations of explosive or flammable gases } \\
\text { are expected to approach the lower flammability limit, } \\
\text { measures shall be taken to prevent deflagration or } \\
\text { detonation. }\end{array}$ & See M. above. \\
\hline $\begin{array}{l}\text { (c) Consideration of Decontamination and } \\
\text { Decommissioning. Areas in new and modifications to } \\
\text { existing low-level waste management facilities that are } \\
\text { subject to contamination with radioactive or other } \\
\text { hazardous materials shall be designed to facilitate } \\
\text { decontamination. For such facilities a proposed } \\
\text { decommissioning method or a conversion method } \\
\text { leading to reuse shall be described. }\end{array}$ & See M. above. \\
\hline $\begin{array}{l}\text { (d) Instrumentation and Control Systems. Engineering } \\
\text { controls shall be incorporated in the design and } \\
\text { engineering of low-level waste treatment and storage } \\
\text { facilities to provide volume inventory data and to prevent } \\
\text { spills, leaks, and overflows from tanks or confinement } \\
\text { systems. }\end{array}$ & See M. above. \\
\hline $\begin{array}{l}\text { (e) Monitoring. Monitoring and/or leak detection } \\
\text { capabilities shall be incorporated in the design and } \\
\text { engineering of low-level waste treatment and storage } \\
\text { facilities to provide rapid identification of failed } \\
\text { confinement and/or other abnormal conditions. }\end{array}$ & See M. above. \\
\hline $\begin{array}{l}\text { (3) Low-Level Waste Disposal Facility Design. The } \\
\text { following facility requirements and general design } \\
\text { criteria, at a minimum, apply: }\end{array}$ & See M. above. \\
\hline $\begin{array}{l}\text { (a) Confinement. Low-level waste systems and } \\
\text { components shall be designed to maintain waste } \\
\text { confinement. }\end{array}$ & See M. above. \\
\hline (b) Ventilation. & See M. above. \\
\hline $\begin{array}{l}1 \text { Design of low-level waste disposal facilities shall } \\
\text { include ventilation, if applicable, through an appropriate } \\
\text { filtration system to maintain the release of radioactive } \\
\text { material in airborne effluents within the requirements } \\
\text { and guidelines specified in applicable requirements. }\end{array}$ & See M. above. \\
\hline 2 When conditions exist for generating gases in & See M. above. \\
\hline
\end{tabular}


Table 2. (continued).

\begin{tabular}{|c|c|}
\hline \multicolumn{2}{|c|}{ Facility Name: CFA-625, Analytical Laboratory } \\
\hline Chapter IV. Low-Level Waste Requirements & Facility Compliance Information \\
\hline $\begin{array}{l}\text { flammable or explosive concentrations, ventilation } \\
\text { systems or other measures shall be provided to keep the } \\
\text { gases in a nonflammable and non-explosive condition. } \\
\text { Where concentrations of explosive or flammable gases } \\
\text { are expected to approach the lower flammability limit, } \\
\text { measures shall be taken to prevent deflagration or } \\
\text { detonation. }\end{array}$ & \\
\hline $\begin{array}{l}\text { (c) Stability. Low-level waste disposal facilities shall be } \\
\text { designed to achieve long-term stability and to minimize } \\
\text { to the extent practical, the need for active maintenance } \\
\text { following final closure. }\end{array}$ & See M. above. \\
\hline $\begin{array}{l}\text { (d) Control of Water. Low-level waste disposal facilities } \\
\text { shall be designed to minimize to the extent practical, the } \\
\text { contact of waste with water during and after disposal. }\end{array}$ & See M. above. \\
\hline $\begin{array}{l}\text { N. Storage and Staging. The following requirements are } \\
\text { in addition to those in Chapter I of this Manual [DOE M } \\
435.1-1 \text { §I.2.F(13)]. }\end{array}$ & $\begin{array}{l}\text { DOE Manual 435.1-1 §I.2.F(13) applies to field element } \\
\text { managers. }\end{array}$ \\
\hline $\begin{array}{l}\text { (1) Storage Prohibitions. Low-level waste in storage } \\
\text { shall not be readily capable of detonation, explosive } \\
\text { decomposition, reaction at anticipated pressures and } \\
\text { temperatures, or explosive reaction with water. Prior to } \\
\text { storage, pyrophoric materials shall be treated, prepared, } \\
\text { and packaged to be nonflammable. }\end{array}$ & NA; this facility does not store LLW. \\
\hline $\begin{array}{l}\text { From DOE G } 435.1-1 \text { Chapter IV: Compliance with this } \\
\text { requirement is demonstrated by having waste acceptance } \\
\text { requirements which prohibit low-level waste that is } \\
\text { ignitable or explosive from being accepted for storage } \\
\text { unless it has been treated, and procedures for properly } \\
\text { preparing such materials for safe storage. }\end{array}$ & \\
\hline $\begin{array}{l}\text { (2) Storage Limit. Low-level waste that has an identified } \\
\text { path to disposal shall not be stored longer than one year } \\
\text { prior to disposal, except for storage for decay, or as } \\
\text { otherwise authorized by the Field Element Manager. }\end{array}$ & $\begin{array}{l}\text { NA; this facility does not store LLW. See N. (7) below } \\
\text { for staging requirements. }\end{array}$ \\
\hline $\begin{array}{l}\text { From DOE G } 435.1-1 \text { Chapter IV: Storage longer than } \\
\text { one year can be justified if the conditions for such } \\
\text { storage are approved by the Field Element Manager as } \\
\text { part of the radioactive waste management basis for the } \\
\text { facility. }\end{array}$ & \\
\hline $\begin{array}{l}\text { Storage for radioactive decay for a period greater than } 1 \\
\text { year for waste that has an identified path to disposal is } \\
\text { allowed. Adequate justification and the supporting } \\
\text { information for storage for decay is to be documented in } \\
\text { the radioactive waste management basis for the facility } \\
\text { in which the storage will take place. }\end{array}$ & \\
\hline $\begin{array}{l}\text { Mixed waste. Under the Federal Facility Compliance Act } \\
\text { of 1992, DOE sites were required to develop Site } \\
\text { Treatment Plans to bring stored mixed low-level waste }\end{array}$ & \\
\hline
\end{tabular}


Table 2. (continued).

Facility Name: CFA-625, Analytical Laboratory

\begin{tabular}{|c|c|}
\hline Chapter IV. Low-Level Waste Requirements & Facility Compliance Information \\
\hline $\begin{array}{l}\text { into compliance with these requirements. The Site } \\
\text { Treatment Plan needs to be consulted and any mixed } \\
\text { low-level waste stored for the purpose of accumulation } \\
\text { to facilitate treatment must meet Resource Conservation } \\
\text { and Recovery Act storage requirements. There could be } \\
\text { several ways within different scenarios that this } \\
\text { requirement can be met, as illustrated by the examples } \\
\text { below, however, there are basically four ways to show } \\
\text { compliance with the requirement and include appropriate } \\
\text { provisions in the radioactive waste management basis for } \\
\text { the facility in which it is stored. }\end{array}$ & \\
\hline $\begin{array}{l}\text { Legacy waste. As discussed above, the intention of the } \\
\text { requirement is not to force malicious compliance or } \\
\text { heroic actions which would result in increased risk or } \\
\text { safety concerns. Rather, the intention is that waste in } \\
\text { storage longer than one year receives additional attention } \\
\text { to ensure that the public, the workers, and the } \\
\text { environment are protected from the hazards of the waste, } \\
\text { and that progress is being made to dispose of the waste. } \\
\text { There could be several ways within different scenarios } \\
\text { that this requirement can be met, as illustrated by the } \\
\text { examples below, however, there are basically four ways } \\
\text { to show compliance with the requirement: }\end{array}$ & \\
\hline $\begin{array}{l}\text { 1) the radioactive waste management basis allows for } \\
\text { storage for no more than one year. }\end{array}$ & \\
\hline $\begin{array}{l}\text { 2) the radioactive waste management basis allows for } \\
\text { storage for no more than one year, or for storage for } \\
\text { decay only for periods greater than a year, which are } \\
\text { specified on a radionuclide basis. }\end{array}$ & \\
\hline $\begin{array}{l}\text { 3) the radioactive waste management basis allows for } \\
\text { storage for more than one year, up to a specified period } \\
\text { of time based on a documented technical evaluation that } \\
\text { the waste can be stored in a manner that does not cause } \\
\text { changes to the waste or waste packages that is } \\
\text { detrimental to the safe storage of the waste, the final } \\
\text { disposal of the waste or to meeting the disposal } \\
\text { performance objectives. }\end{array}$ & \\
\hline $\begin{array}{l}\text { 4) the radioactive waste management basis allows for } \\
\text { storage for decay (with specifics) and for storage for } \\
\text { more than one year for other low-level waste, up to a } \\
\text { specified period of time based on a documented technical } \\
\text { evaluation that the waste can be stored in a manner that } \\
\text { does not cause changes to the waste or waste packages } \\
\text { that is detrimental to the safe storage of the waste, the } \\
\text { final disposal of the waste or to meeting the disposal } \\
\text { performance objectives. }\end{array}$ & \\
\hline $\begin{array}{l}\text { Compliance with this requirement is demonstrated by the } \\
\text { existence of a radioactive waste management basis for }\end{array}$ & \\
\hline
\end{tabular}


Table 2. (continued).

Facility Name: CFA-625, Analytical Laboratory

\begin{tabular}{|c|c|}
\hline Chapter IV. Low-Level Waste Requirements & Facility Compliance Information \\
\hline $\begin{array}{l}\text { the storage facility approved by the Field Element } \\
\text { Manager that includes the time frames that waste are } \\
\text { allowed to be stored, the necessary justifications for } \\
\text { storage for decay, and the necessary technical } \\
\text { evaluations if storage is to extend significantly beyond } \\
\text { the one-year time frame. }\end{array}$ & \\
\hline $\begin{array}{l}\text { (3) Storage Integrity. Low-level waste shall be stored in } \\
\text { a location and manner that protects the integrity of waste } \\
\text { for the expected time of storage and minimizes worker } \\
\text { exposure. }\end{array}$ & $\begin{array}{l}\text { NA; this facility does not store LLW. See N. (7) below } \\
\text { for staging requirements. }\end{array}$ \\
\hline $\begin{array}{l}\text { From DOE G } 435.1-1 \text { Chapter IV: However, in making a } \\
\text { decision to use a facility for storage and in developing a } \\
\text { radioactive waste management basis for the activity, } \\
\text { particular attention to protection of workers is needed. }\end{array}$ & \\
\hline $\begin{array}{l}\text { Compliance with this requirement is demonstrated if } \\
\text { sites have storage capabilities for low-level waste that } \\
\text { provide protection to waste containers so that their } \\
\text { integrity will not be damaged through physical or } \\
\text { chemical (corrosion) processes and that keep personnel } \\
\text { from spending extended periods of time in the areas } \\
\text { where low-level waste is stored. }\end{array}$ & \\
\hline (4) Waste Characterization for Storage. & $\begin{array}{l}\text { NA; this facility does not store LLW. See N. (7) below } \\
\text { for staging requirements. }\end{array}$ \\
\hline $\begin{array}{l}\text { (a) Low-level waste that does not have an identified path } \\
\text { to disposal shall be characterized as necessary to meet } \\
\text { the data quality objectives and minimum characterization } \\
\text { requirements of this Chapter, to ensure safe storage, and } \\
\text { to facilitate disposal. }\end{array}$ & $\begin{array}{l}\text { NA; this facility does not store LLW. See N. (7) below } \\
\text { for staging requirements. }\end{array}$ \\
\hline $\begin{array}{l}\text { (b) Characterization information for all low-level waste } \\
\text { in storage shall be maintained as a record in accordance } \\
\text { with the requirements for Records Management in } \\
\text { Chapter I of this Manual. }\end{array}$ & $\begin{array}{l}\text { NA; this facility does not store LLW. See N. (7) below } \\
\text { for staging requirements. }\end{array}$ \\
\hline $\begin{array}{l}\text { From DOE G 435.1-1 Chapter IV: Compliance with this } \\
\text { requirement is demonstrated by documented procedures } \\
\text { for managing waste characterization and container } \\
\text { information on low-level waste as a Federal record. The } \\
\text { records are managed per the applicable policies and } \\
\text { procedures for records management referenced in DOE } \\
\text { O } 200.1 \text { and established at the applicable Field Element. }\end{array}$ & \\
\hline $\begin{array}{l}\text { (5) Container Inspection. A process shall be developed } \\
\text { and implemented for inspecting and maintaining } \\
\text { containers of low-level waste to ensure container } \\
\text { integrity is not compromised. }\end{array}$ & $\begin{array}{l}\text { LI- } 435 \text { requires quarterly inspections of radioactive waste } \\
\text { containers if waste is stored outdoors or has been in } \\
\text { storage for greater than } 1 \text { year. }\end{array}$ \\
\hline $\begin{array}{l}\text { From DOE G 435.1-1 Chapter IV: Compliance with this } \\
\text { requirement is demonstrated by: (1) a documented } \\
\text { process for waste container inspection and maintenance; } \\
\text { and (2) documentation for all waste container inspections }\end{array}$ & \\
\hline
\end{tabular}


Table 2. (continued).

\begin{tabular}{|c|c|}
\hline \multicolumn{2}{|c|}{ Facility Name: CFA-625, Analytical Laboratory } \\
\hline Chapter IV. Low-Level Waste Requirements & Facility Compliance Information \\
\hline and maintenance actions performed. & \\
\hline $\begin{array}{l}\text { (6) Storage Management. Low-level waste storage shall } \\
\text { be managed to identify and segregate low-level waste } \\
\text { from mixed low-level waste. }\end{array}$ & $\begin{array}{l}\text { NA; this facility does not store LLW. See N. (7) below } \\
\text { for staging requirements. }\end{array}$ \\
\hline $\begin{array}{l}\text { (7) Staging. Staging of low-level waste shall be for the } \\
\text { purpose of the accumulation of such quantities of waste } \\
\text { as necessary to facilitate transportation, treatment, and } \\
\text { disposal. Staging longer than } 90 \text { days shall meet the } \\
\text { requirements for storage above and in Chapter I of this } \\
\text { Manual. }\end{array}$ & $\begin{array}{l}\text { Routine LLW, such as personal protective equipment, is } \\
\text { accumulated at this facility for disposal. MCP-17000, } \\
\text { Appendix F, "Container Start Date and Storage } \\
\text { Prohibitions," restricts staging LLW to } 90 \text { days maximum } \\
\text { at any generator or treatment facility prior to acceptance } \\
\text { by a storage facility. }\end{array}$ \\
\hline $\begin{array}{l}\text { From DOE G } 435.1-1 \text { Chapter IV: The staging of low- } \\
\text { level waste needs to be addressed in the radioactive } \\
\text { waste management basis for the facility that is } \\
\text { performing the staging. Generators, treatment facilities, } \\
\text { and disposal facilities that stage waste must ensure that } \\
\text { the action of staging is included and authorized as part of } \\
\text { their radioactive waste management basis for the } \\
\text { affected facilities, operations, or activities. }\end{array}$ & $\begin{array}{l}\text { As stated in DOE Guide } 435.1-1 \text { §IV.N.(7), staging waste } \\
\text { in accordance with this requirement allows waste to be } \\
\text { accumulated without being considered storage and being } \\
\text { bound by the associated storage requirements. }\end{array}$ \\
\hline $\begin{array}{l}\text { Staging longer than } 90 \text { days must be justified, the } \\
\text { conditions for such storage met, and these practices } \\
\text { approved by the Field Element Manager as part of the } \\
\text { radioactive waste management basis for the facility. }\end{array}$ & \\
\hline $\begin{array}{l}\text { Compliance with this requirement is demonstrated by a } \\
\text { staging program that limits the temporary storage of } \\
\text { waste to only circumstances allowed in the requirement, } \\
\text { including justifications for any staging that exceeds the } \\
90 \text {-day period, which is documented in the radioactive } \\
\text { waste management basis for the facility. }\end{array}$ & \\
\hline $\begin{array}{l}\text { O. Treatment. Low-level waste treatment to provide } \\
\text { more stable waste forms and to improve the long-term } \\
\text { performance of a low-level waste disposal facility shall } \\
\text { be implemented as necessary to meet the performance } \\
\text { objectives of the disposal facility. }\end{array}$ & NA; this facility does not treat LLW. \\
\hline $\begin{array}{l}\text { From DOE G } 435.1-1 \text { Chapter IV: Compliance with this } \\
\text { requirement is demonstrated when a treatment facility or } \\
\text { process ensures that treated waste will meet the } \\
\text { minimum waste form requirements of DOE M } 435.1 \text { and } \\
\text { meet additional disposal facility-specific waste } \\
\text { acceptance requirements for additional stability or long- } \\
\text { term performance of facilities that will receive the } \\
\text { treated waste. }\end{array}$ & \\
\hline $\begin{array}{l}\text { P. Disposal. Low-level waste disposal facilities shall } \\
\text { meet the following requirements. }\end{array}$ & NA; this facility does not dispose of LLW. \\
\hline $\begin{array}{l}\text { (1) Performance Objectives. Low-level waste disposal } \\
\text { facilities shall be sited, designed, operated, maintained, } \\
\text { and closed so that a reasonable expectation exists that the } \\
\text { following performance objectives will be met for waste }\end{array}$ & See P. above. \\
\hline
\end{tabular}


Table 2. (continued).

\begin{tabular}{|c|c|}
\hline \multicolumn{2}{|c|}{ Facility Name: CFA-625, Analytical Laboratory } \\
\hline Chapter IV. Low-Level Waste Requirements & Facility Compliance Information \\
\hline disposed of after September 26, 1988: & \\
\hline $\begin{array}{l}\text { (a) Dose to representative members of the public shall } \\
\text { not exceed } 25 \text { mrem }(0.25 \mathrm{mSv}) \text { in a year total effective } \\
\text { dose equivalent from all exposure pathways, excluding } \\
\text { the dose from radon and its progeny in air. }\end{array}$ & See P. above. \\
\hline $\begin{array}{l}\text { (b) Dose to representative members of the public via the } \\
\text { air pathway shall not exceed } 10 \mathrm{mrem}(0.10 \mathrm{mSv}) \text { in a } \\
\text { year total effective dose equivalent, excluding the dose } \\
\text { from radon and its progeny. }\end{array}$ & See P. above. \\
\hline $\begin{array}{l}\text { (c) Release of radon shall be less than an average flux of } \\
20 \mathrm{pCi} / \mathrm{m}^{2} / \mathrm{s}\left(0.74 \mathrm{~Bq} / \mathrm{m}^{2} / \mathrm{s}\right) \text { at the surface of the disposal } \\
\text { facility. Alternatively, a limit of } 0.5 \mathrm{pCi} / 1(0.0185 \mathrm{~Bq} / \mathrm{l}) \\
\text { of air may be applied at the boundary of the facility. }\end{array}$ & See P. above. \\
\hline $\begin{array}{l}\text { (2) Performance Assessment. A site-specific radiological } \\
\text { performance assessment shall be prepared and } \\
\text { maintained for DOE low-level waste disposed of after } \\
\text { September } 26,1988 \text {. The performance assessment shall } \\
\text { include calculations for a } 1,000 \text { year period after closure } \\
\text { of potential doses to representative future members of } \\
\text { the public and potential releases from the facility to } \\
\text { provide a reasonable expectation that the performance } \\
\text { objectives identified in this Chapter are not exceeded as } \\
\text { a result of operation and closure of the facility. }\end{array}$ & See P. above. \\
\hline $\begin{array}{l}\text { (a) Analyses performed to demonstrate compliance with } \\
\text { the performance objectives in this Chapter, and to } \\
\text { establish limits on concentrations of radionuclides for } \\
\text { disposal based on the performance measures for } \\
\text { inadvertent intruders in this Chapter shall be based on } \\
\text { reasonable activities in the critical group of exposed } \\
\text { individuals. Unless otherwise specified, the assumption } \\
\text { of average living habits and exposure conditions in } \\
\text { representative critical groups of individuals projected to } \\
\text { receive the highest doses is appropriate. The likelihood } \\
\text { of inadvertent intruder scenarios may be considered in } \\
\text { interpreting the results of the analyses and establishing } \\
\text { radionuclide concentrations, if adequate justification is } \\
\text { provided. }\end{array}$ & See P. above. \\
\hline $\begin{array}{l}\text { (b) The point of compliance shall correspond to the point } \\
\text { of highest projected dose or concentration beyond a } 100 \\
\text { meter buffer zone surrounding the disposed waste. A } \\
\text { larger or smaller buffer zone may be used if adequate } \\
\text { justification is provided. }\end{array}$ & See P. above. \\
\hline $\begin{array}{l}\text { (c) Performance assessments shall address reasonably } \\
\text { foreseeable natural processes that might disrupt barriers } \\
\text { against release and transport of radioactive materials. }\end{array}$ & See P. above. \\
\hline $\begin{array}{l}\text { (d) Performance assessments shall use DOE-approved } \\
\text { dose coefficients (dose conversion factors) for internal }\end{array}$ & See P. above. \\
\hline
\end{tabular}


Table 2. (continued).

\begin{tabular}{|c|c|}
\hline \multicolumn{2}{|c|}{ Facility Name: CFA-625, Analytical Laboratory } \\
\hline Chapter IV. Low-Level Waste Requirements & Facility Compliance Information \\
\hline and external exposure of reference adults. & \\
\hline $\begin{array}{l}\text { (e) The performance assessment shall include a } \\
\text { sensitivity/uncertainty analysis. }\end{array}$ & See P. above. \\
\hline $\begin{array}{l}\text { (f) Performance assessments shall include a } \\
\text { demonstration that projected releases of radionuclides to } \\
\text { the environment shall be maintained as low as } \\
\text { reasonably achievable (ALARA). }\end{array}$ & See P. above. \\
\hline $\begin{array}{l}\text { (g) For purposes of establishing limits on radionuclides } \\
\text { that may be disposed of near-surface, the performance } \\
\text { assessment shall include an assessment of impacts to } \\
\text { water resources. }\end{array}$ & See P. above. \\
\hline $\begin{array}{l}\text { (h) For purposes of establishing limits on the } \\
\text { concentration of radionuclides that may be disposed of } \\
\text { near-surface, the performance assessment shall include } \\
\text { an assessment of impacts calculated for a hypothetical } \\
\text { person assumed to inadvertently intrude for a temporary } \\
\text { period into the low-level waste disposal facility. For } \\
\text { intruder analyses, institutional controls shall be assumed } \\
\text { to be effective in deterring intrusion for at least } 100 \text { years } \\
\text { following closure. The intruder analyses shall use } \\
\text { performance measures for chronic and acute exposure } \\
\text { scenarios, respectively, of } 100 \text { mrem ( } 1 \mathrm{mSv}) \text { in a year } \\
\text { and } 500 \text { mrem }(5 \mathrm{mSv}) \text { total effective dose equivalent } \\
\text { excluding radon in air. }\end{array}$ & See P. above. \\
\hline $\begin{array}{l}\text { (3) Composite Analysis. For disposal facilities which } \\
\text { received waste after September } 26,1988 \text {, a site-specific } \\
\text { radiological composite analysis shall be prepared and } \\
\text { maintained that accounts for all sources of radioactive } \\
\text { material that may be left at the DOE site and may } \\
\text { interact with the low- level waste disposal facility, } \\
\text { contributing to the dose projected to a hypothetical } \\
\text { member of the public from the existing or future disposal } \\
\text { facilities. Performance measures shall be consistent with } \\
\text { DOE requirements for protection of the public and } \\
\text { environment and evaluated for a } 1,000 \text { year period } \\
\text { following disposal facility closure. The composite } \\
\text { analysis results shall be used for planning, radiation } \\
\text { protection activities, and future use commitments to } \\
\text { minimize the likelihood that current low- level waste } \\
\text { disposal activities will result in the need for future } \\
\text { corrective or remedial actions to adequately protect the } \\
\text { public and the environment. }\end{array}$ & \begin{tabular}{|l} 
See P. above. \\
$\mid$
\end{tabular} \\
\hline $\begin{array}{l}\text { (4) Performance Assessment and Composite Analysis } \\
\text { Maintenance. The performance assessment and } \\
\text { composite analysis shall be maintained to evaluate } \\
\text { changes that could affect the performance, design, and } \\
\text { operating bases for the facility. Performance assessment } \\
\text { and composite analysis maintenance shall include the }\end{array}$ & See P. above. \\
\hline
\end{tabular}


Table 2. (continued).

Facility Name: CFA-625, Analytical Laboratory

Chapter IV. Low-Level Waste Requirements Facility Compliance Information

conduct of research, field studies, and monitoring needed to address uncertainties or gaps in existing data. The performance assessment shall be updated to support the final facility closure. Additional iterations of the performance assessment and composite analysis shall be conducted as necessary during the post-closure period.

(a) Performance assessments and composite analyses shall be reviewed and revised when changes in waste forms or containers, radionuclide inventories, facility design and operations, closure concepts, or the improved understanding of the performance of the waste disposal facility in combination with the features of the site on which it is located alter the conclusions or the conceptual model(s) of the existing performance assessment or composite analysis.

(b) A determination of the continued adequacy of the See P. above. performance assessment and composite analysis shall be made on an annual basis, and shall consider the results of data collection and analysis from research, field studies, and monitoring.

(c) Annual summaries of low-level waste disposal operations shall be prepared with respect to the conclusions and recommendations of the performance assessment and composite analysis and a determination of the need to revise the performance assessment or composite analysis.

(5) Disposal Authorization. A disposal authorization statement shall be obtained prior to construction of a new low-level waste disposal facility. Field Elements with existing low-level waste disposal facilities shall obtain a disposal authorization statement in accordance with the schedule in the Complex-Wide Low-Level Waste Management Program Plan. The disposal authorization statement shall be issued based on a review of the facility's performance assessment, composite analysis, performance assessment and composite analysis maintenance, preliminary closure plan, and preliminary monitoring plan. The disposal authorization statement shall specify the limits and conditions on construction, design, operations, and closure of the low-level waste facility based on these reviews. A disposal authorization statement is a part of the radioactive waste management basis for a disposal facility. Failure to obtain a disposal authorization statement by the implementation date of this Order shall result in shutdown of the disposal facility.

(6) Disposal Facility Operations. The disposal facility design and operation must be consistent with the disposal facility closure plan and lead to disposal facility

See P. above.

See P. above.

See P. above. 
Table 2. (continued).

Facility Name: CFA-625, Analytical Laboratory

\begin{tabular}{|c|c|}
\hline Chapter IV. Low-Level Waste Requirements & Facility Compliance Information \\
\hline $\begin{array}{l}\text { closure that provides a reasonable expectation that } \\
\text { performance objectives will be met. Low-level waste } \\
\text { shall be disposed in such a manner that achieves the } \\
\text { performance objectives stated in this Chapter, consistent } \\
\text { with the disposal facility radiological performance } \\
\text { assessment. Additional requirements include: }\end{array}$ & \\
\hline $\begin{array}{l}\text { (a) Operating procedures shall be developed and } \\
\text { implemented for low-level waste disposal facilities that } \\
\text { protect the public, workers, and the environment; ensure } \\
\text { the security of the facility; minimize subsidence during } \\
\text { and after waste emplacement; achieve long-term stability } \\
\text { and minimize the need for long-term active maintenance; } \\
\text { and meet the requirements of the closure/post-closure } \\
\text { plan. }\end{array}$ & See P. above. \\
\hline $\begin{array}{l}\text { (b) Permanent identification markers for disposal } \\
\text { excavations and monitoring wells shall be emplaced. }\end{array}$ & See P. above. \\
\hline $\begin{array}{l}\text { (c) Low-level waste placement into disposal units shall } \\
\text { minimize voids between waste containers. Voids within } \\
\text { disposal units shall be filled to the extent practical. } \\
\text { Uncontainerized bulk waste shall also be placed in a } \\
\text { manner that minimizes voids and subsidence. }\end{array}$ & See P. above. \\
\hline $\begin{array}{l}\text { (d) Operations are to be conducted so that active waste } \\
\text { disposal operations will not have an adverse effect on } \\
\text { any other disposal units. }\end{array}$ & See P. above. \\
\hline $\begin{array}{l}\text { (e) Operations shall include a process for tracking and } \\
\text { documenting low-level waste placement in the facility by } \\
\text { generator source. }\end{array}$ & See P. above. \\
\hline $\begin{array}{l}\text { (7) Alternate Requirements for Low-Level Waste } \\
\text { Disposal Facility Design and Operation. Requirements } \\
\text { other than those set forth in this Section for the design } \\
\text { and operation of a low-level waste disposal facility may } \\
\text { be approved on a specific basis if a reasonable } \\
\text { expectation is demonstrated that the disposal } \\
\text { performance objectives will be met. }\end{array}$ & See P. above. \\
\hline $\begin{array}{l}\text { Q. Closure. The following requirements are in addition } \\
\text { to those in Chapter I of this Manual. }\end{array}$ & NA; this facility does not dispose of LLW. \\
\hline $\begin{array}{l}\text { (1) Disposal Facility Closure Plans. A preliminary } \\
\text { closure plan shall be developed and submitted to } \\
\text { Headquarters for review with the performance } \\
\text { assessment and composite analysis. The closure plan } \\
\text { shall be updated following issuance of the disposal } \\
\text { authorization statement to incorporate conditions } \\
\text { specified in the disposal authorization statement. Closure } \\
\text { plans shall: }\end{array}$ & See Q. above. \\
\hline $\begin{array}{l}\text { (a) Be updated as required during the operational life of } \\
\text { the facility. }\end{array}$ & See Q. above. \\
\hline
\end{tabular}


Table 2. (continued).

\begin{tabular}{|c|c|}
\hline \multicolumn{2}{|c|}{ Facility Name: CFA-625, Analytical Laboratory } \\
\hline Chapter IV. Low-Level Waste Requirements & Facility Compliance Information \\
\hline $\begin{array}{l}\text { (b) Include a description of how the disposal facility will } \\
\text { be closed to achieve long-term stability and minimize the } \\
\text { need for active maintenance following closure and to } \\
\text { ensure compliance with the requirements of DOE } \\
5400.5, \text { Radiation Protection of the Public and the } \\
\text { Environment. }\end{array}$ & See Q. above. \\
\hline $\begin{array}{l}\text { (c) Include the total expected inventory of wastes to be } \\
\text { disposed of at the facility over the operational life of the } \\
\text { facility. }\end{array}$ & See Q. above. \\
\hline $\begin{array}{l}\text { (2) Disposal Facility Closure. Closure of a disposal } \\
\text { facility shall occur within a five-year period after it is } \\
\text { filled to capacity, or after the facility is otherwise } \\
\text { determined to be no longer needed. }\end{array}$ & See Q. above. \\
\hline $\begin{array}{l}\text { (a) Prior to facility closure, the final inventory of the } \\
\text { low-level waste disposed in the facility shall be prepared } \\
\text { and incorporated in the performance assessment and } \\
\text { composite analysis which shall be updated to support the } \\
\text { closure of the facility. }\end{array}$ & See Q. above. \\
\hline $\begin{array}{l}\text { (b) A final closure plan shall be prepared based on the } \\
\text { final inventory of waste disposed in the facility, the plan } \\
\text { implemented, and the updated performance assessment } \\
\text { and composite analysis prepared in support of the facility } \\
\text { closure. }\end{array}$ & See Q. above. \\
\hline $\begin{array}{l}\text { (c) Institutional control measures shall be integrated into } \\
\text { land use and stewardship plans and programs, and shall } \\
\text { continue until the facility can be released pursuant to } \\
\text { DOE 5400.5, Radiation Protection of the Public and the } \\
\text { Environment. }\end{array}$ & See Q. above. \\
\hline $\begin{array}{l}\text { (d) The location and use of the facility shall be filed with } \\
\text { the local authorities responsible for land use and zoning. }\end{array}$ & See Q. above. \\
\hline $\begin{array}{l}\text { R. Monitoring. The following requirements are in } \\
\text { addition to those in Chapter I of this Manual [DOE M } \\
435.1-1 \text { §I.1.E(7)]. }\end{array}$ & $\begin{array}{l}\text { DOE Manual 435.1-1 §I.1.E(7) applies to field element } \\
\text { managers. }\end{array}$ \\
\hline $\begin{array}{l}\text { (1) All Waste Facilities. Parameters that shall be sampled } \\
\text { or monitored, at a minimum, include: temperature, } \\
\text { pressure (for closed systems), radioactivity in ventilation } \\
\text { exhaust and liquid effluent streams, and flammable or } \\
\text { explosive mixtures of gases. Facility monitoring }\end{array}$ & $\begin{array}{l}\text { Monitoring requirements at INL radioactive waste } \\
\text { management facilities are tailored for the specific facility } \\
\text { to enable timely indication of developing problems. } \\
\text { Existing radiological control procedures and assessments } \\
\text { are followed/completed to monitor waste facilities. }\end{array}$ \\
\hline & $\begin{array}{l}\text { LRD-15001 and MCP-139 specify methods and } \\
\text { frequency of radiological control surveys of all }\end{array}$ \\
\hline $\begin{array}{l}\text { From DOE G } 435.1-1 \text { Chapter IV: The minimum } \\
\text { parameters specified in the requirement were selected } \\
\text { based on their potential significance for anticipating and } \\
\text { identifying undesirable conditions at low-level waste } \\
\text { management facilities. Each facility's radioactive waste } \\
\text { management basis should include an evaluation of the }\end{array}$ & $\begin{array}{l}\text { radiological areas. MCP-139 specifies the use of } \\
\text { Form } 441 . \text { A34. This form is referred to as the "routine } \\
\text { sheet" and is to be used by facility radiological control } \\
\text { foremen to list radiological areas that are to be surveyed, } \\
\text { the survey periods, and methods. }\end{array}$ \\
\hline
\end{tabular}


Table 2. (continued).

Facility Name: CFA-625, Analytical Laboratory

\begin{tabular}{|c|c|}
\hline Chapter IV. Low-Level Waste Requirements & Facility Compliance Information \\
\hline $\begin{array}{l}\text { applicability and significance of the minimum } \\
\text { parameters. This evaluation also needs to consider } \\
\text { additional parameters to be sampled or monitored to } \\
\text { ensure the protection of the public health, the } \\
\text { environment, and the workers. If a minimum parameter } \\
\text { specified in the requirement is deemed to be not } \\
\text { applicable in any way to the active operation of that } \\
\text { facility, then that justification should be included in the } \\
\text { radioactive waste management basis and when approved } \\
\text { constitutes an exemption to the manual. }\end{array}$ & \\
\hline $\begin{array}{l}\text { Verification activities are part of the radioactive waste } \\
\text { management basis as a condition for operation and } \\
\text { documented appropriately. }\end{array}$ & \\
\hline $\begin{array}{l}\text { Compliance with this requirement is demonstrated if } \\
\text { monitoring or sampling for the stated parameters is } \\
\text { performed for all facilities with a precision, accuracy, } \\
\text { and frequency consistent with timely identification of } \\
\text { developing problems and a justification exists in the } \\
\text { approved radioactive waste management basis for those } \\
\text { specified parameters which are not monitored or } \\
\text { sampled. }\end{array}$ & \\
\hline $\begin{array}{l}\text { (2) Liquid Waste Storage Facilities. For facilities storing } \\
\text { liquid low-level waste, the following shall also be } \\
\text { monitored: liquid level and/or waste volume, and } \\
\text { significant waste chemistry parameters. }\end{array}$ & NA; liquid LLW is not stored in this facility. \\
\hline $\begin{array}{l}\text { (3) Disposal Facilities. A preliminary monitoring plan } \\
\text { for a low-level waste disposal facility shall be prepared } \\
\text { and submitted to Headquarters for review with the } \\
\text { performance assessment and composite analysis. The } \\
\text { monitoring plan shall be updated within one year } \\
\text { following issuance of the disposal authorization } \\
\text { statement to incorporate and implement conditions } \\
\text { specified in the disposal authorization statement. }\end{array}$ & NA; this facility does not dispose of LLW. \\
\hline $\begin{array}{l}\text { (a) The site-specific performance assessment and } \\
\text { composite analysis shall be used to determine the media, } \\
\text { locations, radionuclides, and other substances to be } \\
\text { monitored. }\end{array}$ & See (3) above. \\
\hline $\begin{array}{l}\text { (b) The environmental monitoring program shall be } \\
\text { designed to include measuring and evaluating releases, } \\
\text { migration of radionuclides, disposal unit subsidence, and } \\
\text { changes in disposal facility and disposal site parameters } \\
\text { which may affect long-term performance. }\end{array}$ & See (3) above. \\
\hline $\begin{array}{l}\text { (c) The environmental monitoring programs shall be } \\
\text { capable of detecting changing trends in performance to } \\
\text { allow application of any necessary corrective action prior } \\
\text { to exceeding the performance objectives in this Chapter. }\end{array}$ & See (3) above. \\
\hline
\end{tabular}




\subsection{CFA-637, Bunker}

1. Facility Description: CFA-637 is a one-story, "igloo-type" building. The building is constructed of reinforced concrete. The roof and walls are earth-covered. The building sits on a reinforced concrete slab, was built in 1943, and covers approximately 2,230 $\mathrm{ft}^{2}$. There are two rooms in the building separated by fire doors. The building is currently being used for waste management and contains several SAAs, a 90-day storage area, polychlorinated biphenyls storage, Comprehensive Environmental Response, Compensation, and Liability Act (CERCLA) waste storage, universal waste storage, radioactive waste storage, and other nonregulated waste storage. The facility is normally unoccupied and is open for operation for a short-period of time each day.

Room 102 is approximately $18 \times 24 \mathrm{ft}$ and houses the 90 -day storage area, the radioactive material area, and a chemical waste storage SAA. The radioactive material area stores low-level radioactive waste and soil standards with small activity levels. The 90-day storage area provides storage of Resource Conservation Recovery Act (RCRA)-regulated waste for short-term storage prior to shipment to a RCRA-regulated storage or disposal facility. Typically the waste is paints, solvents, spill cleanup materials, and other chemicals generated from maintenance activities around CFA. However, on occasion, unknown materials are discovered that require sampling and analysis to characterize the waste. In the past, this included gasoline, used motor oil, organic liquids, and sludge. The chemical storage SAA collects maintenance types of chemicals that are no longer usable as product. This waste is usually chemical test kits, paints, aerosols, and other flammable types of waste. On occasion, acids and bases will be generated. The acids, bases, and flammables are all stored separately to prevent potential reactions.

Room 101 is separated into three sections by approximately 6 -in. containment curbs. The first section provides storage for lead acid batteries, nonradiologically contaminated lead, and printed circuit boards. The second section contains storage of universal waste (e.g., batteries and lamps), SAAs, polychlorinated biphenyl articles, polychlorinated biphenyl-contaminated oils, and recyclable used oil. The SAAs are for mercury, lead-contaminated debris, and high intensity discharge lamps. The mercury is generally from thermostat switches and thermometers; however, laboratory elemental mercury has been received in the past. The third section contains the CERCLA storage area and non-RCRA-regulated and nonradioactive waste. The CERCLA area generally contains personal protective equipment and liquids from CERCLA remediation areas across CFA.

2. Hazard category: LTHC3 radiological

3. Radioactive waste management activities at this facility: Routine contact-handled LLW and mixed LLW is staged at this facility.

4. RWMB documents/programs:

a) Safety basis/hazards analysis:

- HAD-245, "Hazard Assessment Document for the Hazardous Chemical Storage Facility (CFA-637) Hazard Classification"

b) Laboratory-wide:

- Form 441.A34, "INL Radiological Control Required Surveys"

- LI-435, "Waste Management Routine Field Activities"

- LRD-15001, "Radiological Control Manual"

- LWP-13840, "Management of Issues, Observations, and Noteworthy Practices"

- LWP-14002, "Timeout and Stop Work Authority"

- LWP-15011, "Radioactive Material Areas and Radioactive Storage Areas" 
- LWP-17000, "Waste Management"

- MCP-139, "Radiological Surveys"

- MCP-17000, "Waste Generator Services Waste Management"

- MCP-17410, "Management of Waste Storage Areas"

- MCP-17500, "Waste Generator Services Certification of Waste Shipments to the Nevada Test Site"

- PLN-114, "INL Emergency Plan/RCRA Contingency Plan"

- PLN-522, "Quality Assurance Program Plan for the Waste Management/Waste Certification Program"

c) Facility-specific:

- IAG-129, "Tenant Use Agreement Between Laboratory Support Complex and CFA-637 Hazard Chemical Storage Waste Generator Services (WGS)."

LLW is managed at this facility. Table 3 presents the facility compliance information for Chapter IV, "Low-level Waste Requirements."

Table 3. CFA-637, Bunker, DOE Manual 435.1-1 low-level waste requirements and facility compliance information.

\begin{tabular}{|l|l|}
\hline \multicolumn{2}{|c|}{ Facility Name: CFA-637, Bunker } \\
\hline \multicolumn{1}{|c|}{ Chapter IV. Low-Level Waste Requirements } & \multicolumn{1}{|c|}{ Facility Compliance Information } \\
\hline $\begin{array}{l}\text { A. Definition of Low-Level Waste. Low-level } \\
\text { radioactive waste is radioactive waste that is not high- } \\
\text { level radioactive waste, spent nuclear fuel, transuranic } \\
\text { waste, byproduct material (as defined in section 11e.(2) } \\
\text { of the Atomic Energy Act of 1954, as amended), or } \\
\text { naturally occurring radioactive material. }\end{array}$ & $\begin{array}{l}\text { This requirement provides the criteria for determining } \\
\text { which DOE radioactive waste is to be managed as LLW } \\
\text { in accordance with DOE Manual 435.1-1, Chapter IV. } \\
\text { Radioactive waste managed at this facility under the } \\
\text { requirements of this chapter is not managed under the } \\
\text { requirements of DOE Manual 435.1-1 Chapter II or } \\
\text { Chapter III. }\end{array}$ \\
$\begin{array}{l}\text { From DOE G 435.1-1 Chapter IV: Low-level } \\
\text { radioactive waste is defined by what it is not. The } \\
\text { guidance on definitions in Chapters II and III should be } \\
\text { consulted first for making a determination on how to } \\
\text { properly manage a suspect waste stream.) }\end{array}$ & \\
\hline $\begin{array}{l}\text { B. Management of Specific Wastes. The following } \\
\text { provide for management of specific wastes as low-level } \\
\text { waste in accordance with the requirements in this } \\
\text { Chapter: }\end{array}$ & See (1), (2), (3), (4) below. \\
\hline $\begin{array}{l}\text { (1) Mixed Low-Level Waste. Low-level waste } \\
\text { determined to contain both source, special nuclear, or } \\
\text { byproduct material subject to the Atomic Energy Act of } \\
\text { 1954, as amended, and a hazardous component subject to } \\
\text { the Resource Conservation and Recovery Act (RCRA), } \\
\text { as amended, shall be managed in accordance with the } \\
\text { requirements of RCRA and DOE O 435.1, Radioactive } \\
\text { Waste Management, and this Manual. }\end{array}$ & $\begin{array}{l}\text { Management of TAAs is addressed in MCP-17410 and } \\
\text { overall management of mixed waste is addressed in }\end{array}$ \\
\hline $\begin{array}{l}\text { (2) TSCA-Regulated Waste. Low-level waste containing } \\
\text { polychlorinated biphenyls, asbestos, or other such } \\
\text { regulated toxic components shall be managed in } \\
\text { accordance with requirements derived from the Toxic } \\
\text { Substances Control Act, as amended, DOE O 435.1, }\end{array}$ & NA; this facility does not manage TSCA regulated waste. \\
\hline
\end{tabular}


Table 3. (continued).

\begin{tabular}{|c|c|}
\hline \multicolumn{2}{|c|}{ Facility Name: CFA-637, Bunker } \\
\hline Chapter IV. Low-Level Waste Requirements & Facility Compliance Information \\
\hline Radioactive Waste Management, and this Manual. & \\
\hline $\begin{array}{l}\text { (3) Accelerator-Produced Waste. Radioactive waste } \\
\text { produced as a result of operations of DOE accelerators is } \\
\text { low-level waste and shall be managed in accordance with } \\
\text { DOE O 435.1, Radioactive Waste Management, and this } \\
\text { Manual, and all applicable Federal or State requirements. }\end{array}$ & $\begin{array}{l}\text { NA; this facility does not manage accelerator-produced } \\
\text { waste. }\end{array}$ \\
\hline $\begin{array}{l}\text { (4) 11e.(2) and Naturally Occurring Radioactive } \\
\text { Material. Small quantities of 11e.(2) byproduct material } \\
\text { and naturally occurring radioactive material may be } \\
\text { managed as low-level waste provided they can be } \\
\text { managed to meet the requirements for low-level waste } \\
\text { disposal in Section IV.P of this Manual. }\end{array}$ & $\begin{array}{l}\text { NA; this facility does not manage naturally occurring } \\
\text { radioactive material. }\end{array}$ \\
\hline $\begin{array}{l}\text { C. Complex-Wide Low-Level Waste Management } \\
\text { Program. A complex-wide program and plan shall be } \\
\text { developed as described under Responsibilities, } 2 . \mathrm{B} \text { and } \\
\text { 2.D, in Chapter I of this Manual. }\end{array}$ & $\begin{array}{l}\text { Not a facility-specific requirement. DOE Manual 435.1-1 } \\
\text { §I.2.B and §I.2.D apply to the Assistant Secretary for } \\
\text { Environmental Management and the Deputy Assistant } \\
\text { Secretary for Waste Management, respectively. }\end{array}$ \\
\hline $\begin{array}{l}\text { D. Radioactive Waste Management Basis. Low-level } \\
\text { waste facilities, operations, and activities shall have a } \\
\text { radioactive waste management basis consisting of } \\
\text { physical and administrative controls to ensure the } \\
\text { protection of workers, the public, and the environment. }\end{array}$ & $\begin{array}{l}\text { The RWMB provides the regulatory framework for } \\
\text { management of radioactive waste at INL. It specifically } \\
\text { identifies facility management and implementing } \\
\text { documents for the generation, storage, treatment, and } \\
\text { disposal of radiological waste. }\end{array}$ \\
\hline $\begin{array}{l}\text { The following specific waste management controls shall } \\
\text { be part of the radioactive waste management basis: }\end{array}$ & HAD-245 establishes CFA-637 LTHC3 facility. \\
\hline (1) Generators. The waste certification program. & NA; this facility does not generate LLW. \\
\hline $\begin{array}{l}\text { From DOE G } 435.1-1 \text { Chapter IV: For a facility that } \\
\text { generates low-level waste, the radioactive waste } \\
\text { management basis is to include the program for } \\
\text { certifying that waste meets the waste acceptance } \\
\text { requirements of the facility(ies) to which the waste will } \\
\text { be sent. }\end{array}$ & \\
\hline $\begin{array}{l}\text { (2) Treatment Facilities. certification program. The waste } \\
\text { acceptance requirements and the waste [sic] }\end{array}$ & NA; this facility does not treat LLW. \\
\hline $\begin{array}{l}\text { From DOE G } 435.1-1 \text { Chapter IV: Facilities that store or } \\
\text { treat low-level waste are to have approved waste } \\
\text { acceptance requirements (see DOE M } 435.1-1 \text {, Section } \\
\text { IV.G) prior to the issuance of a radioactive waste } \\
\text { management basis. }\end{array}$ & \\
\hline $\begin{array}{l}\text { A facility that stores or treats waste also is generally } \\
\text { expected to have a waste certification program. Waste } \\
\text { from these facilities will have to be certified as meeting } \\
\text { the waste acceptance requirements of the facility to } \\
\text { which it will be transferred, and the facilities have the } \\
\text { potential for generating radioactive waste (e.g., } \\
\text { secondary processing streams from treatment, } \\
\text { monitoring and sampling, radioactive release cleanup). } \\
\text { Consequently, storage and treatment facilities should } \\
\text { also have an approved waste certification program as }\end{array}$ & \\
\hline
\end{tabular}


Table 3. (continued).

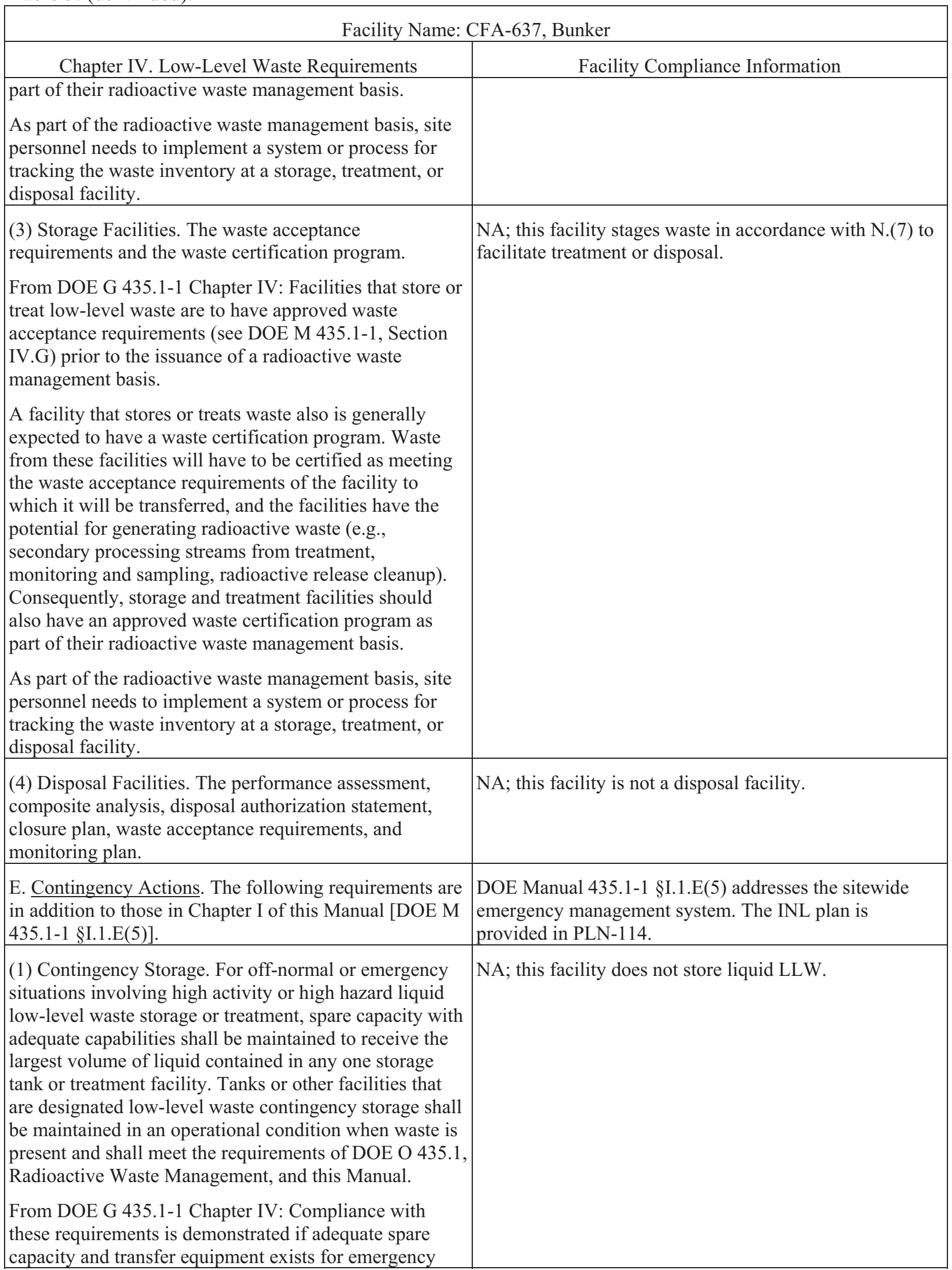


Table 3. (continued).

\begin{tabular}{|c|c|}
\hline \multicolumn{2}{|c|}{ Facility Name: CFA-637, Bunker } \\
\hline Chapter IV. Low-Level Waste Requirements & Facility Compliance Information \\
\hline $\begin{array}{l}\text { transfers of all high activity and high hazard liquid low- } \\
\text { level waste. In addition, the capability to perform } \\
\text { emergency transfers is demonstrated by having waste } \\
\text { transfer routings identified, operational procedures to } \\
\text { direct transfers, staff trained to the procedures, and } \\
\text { records showing that the spare capacity and transfer } \\
\text { capability are kept in operating condition. }\end{array}$ & \\
\hline $\begin{array}{l}\text { (2) Transfer Equipment. Pipelines and auxiliary facilities } \\
\text { necessary for the transfer of high activity or high hazard } \\
\text { liquid low-level waste to contingency storage shall be } \\
\text { maintained in an operational condition when waste is } \\
\text { present and shall meet the requirements of DOE O 435.1, } \\
\text { Radioactive Waste Management, and this Manual. }\end{array}$ & NA; this facility does not store or treat liquid LLW. \\
\hline $\begin{array}{l}\text { From DOE G } 435.1-1 \text { Chapter IV: Compliance with } \\
\text { these requirements is demonstrated if adequate spare } \\
\text { capacity and transfer equipment exists for emergency } \\
\text { transfers of all high activity and high hazard liquid low- } \\
\text { level waste. In addition, the capability to perform } \\
\text { emergency transfers is demonstrated by having waste } \\
\text { transfer routings identified, operational procedures to } \\
\text { direct transfers, staff trained to the procedures, and } \\
\text { records showing that the spare capacity and transfer } \\
\text { capability are kept in operating condition. }\end{array}$ & \\
\hline $\begin{array}{l}\text { F. Corrective Actions. I of this Manual. The following } \\
\text { requirements are in addition to those in Chapter [sic] }\end{array}$ & $\begin{array}{l}\text { The INL-wide procedure addressing problem } \\
\text { identification as required by DOE Manual 435.1-1 }\end{array}$ \\
\hline $\begin{array}{l}\text { From DOE G 435.1-1 Chapter IV: Compliance with } \\
\text { DOE M 435.1-1 §I.2.G.(1) is demonstrated by records }\end{array}$ & $\begin{array}{l}\text { \$1.2.G.(1) 1S LWP-13840, which implements the } \\
\text { laboratory's corrective action system. }\end{array}$ \\
\hline $\begin{array}{l}\text { showing what corrective actions were taken to remedy } \\
\text { situations in the radioactive waste management system. }\end{array}$ & $\begin{array}{l}\text { The INL-wide procedure addressing shutdown or } \\
\text { curtailment of activities as required by DOE }\end{array}$ \\
\hline $\begin{array}{l}\text { Compliance with DOE M 435.1-1 } \S \text { I.2.G.(2) is } \\
\text { demonstrated by having the necessary procedures, } \\
\text { mechanisms, and training in place to effect shutdown or } \\
\text { curtailment of activities which pose an imminent danger } \\
\text { or other serious hazard to workers or the public, or are } \\
\text { not protective of the environment. }\end{array}$ & Manual 435.1-1 §I.2.G.(2) is LWP-14002. \\
\hline $\begin{array}{l}\text { (1) Order Compliance. Corrective actions shall be } \\
\text { implemented whenever necessary to ensure the } \\
\text { requirements of DOE O } 435.1 \text {, Radioactive Waste } \\
\text { Management, and this Manual are met. }\end{array}$ & See F. above. \\
\hline $\begin{array}{l}\text { From DOE G } 435.1-1 \text { Chapter IV: If a facility or activity } \\
\text { can be allowed to operate while a noncompliant or } \\
\text { hazardous condition exists, the allowance and any } \\
\text { associated limitations must be defined as part of the } \\
\text { facility or activity's radioactive waste management basis, } \\
\text { identified as a configuration controlled item in a } \\
\text { configuration management plan or included in a revision } \\
\text { or modification to an operating procedure or similar } \\
\text { controlled documentation. }\end{array}$ & \\
\hline
\end{tabular}


Table 3. (continued).

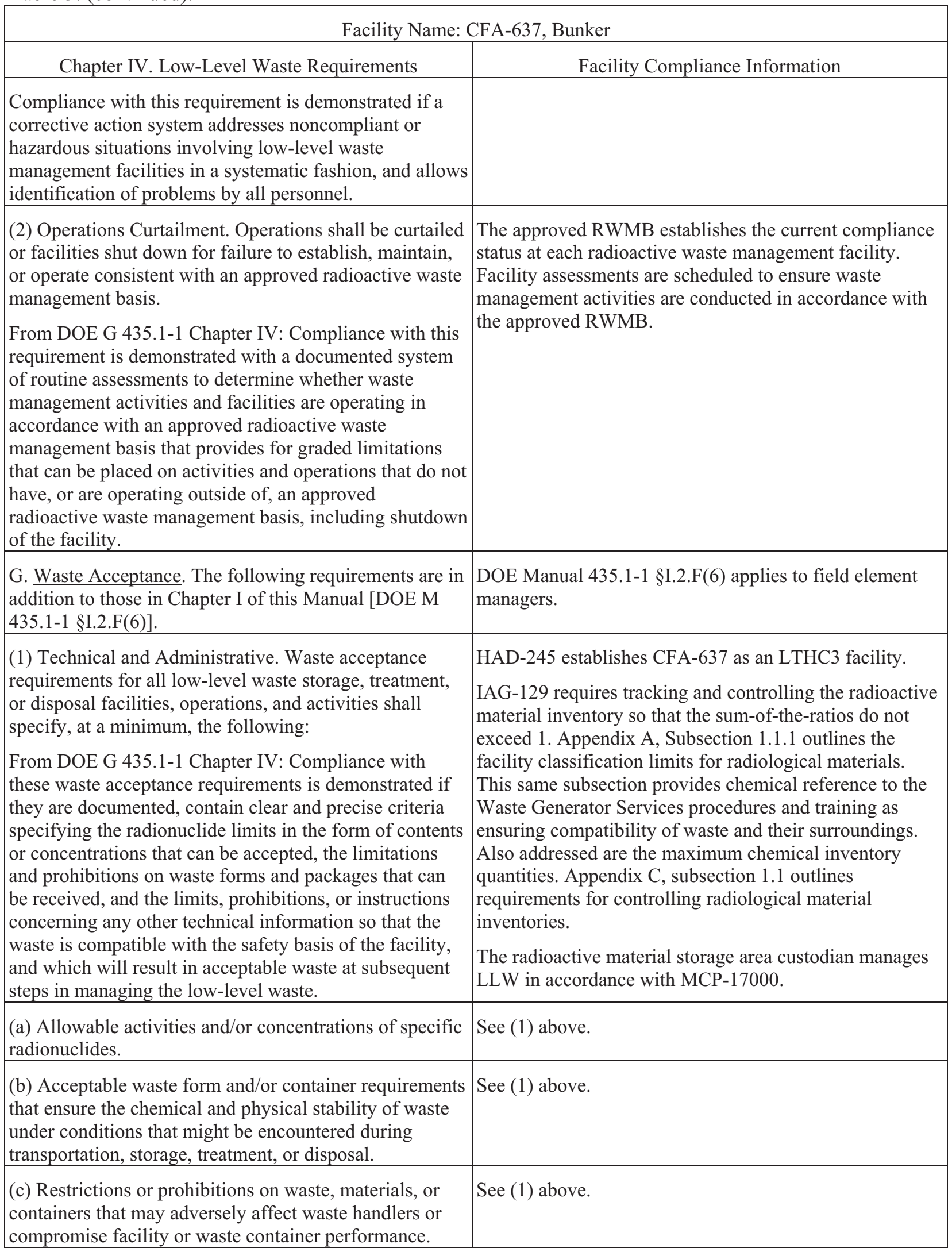


Table 3. (continued).

\begin{tabular}{|c|c|}
\hline \multicolumn{2}{|c|}{ Facility Name: CFA-637, Bunker } \\
\hline Chapter IV. Low-Level Waste Requirements & Facility Compliance Information \\
\hline $\begin{array}{l}\text { (d) The following are additional waste acceptance } \\
\text { requirements that shall be specified in low-level waste } \\
\text { disposal facility waste acceptance requirements: }\end{array}$ & See (1) above. \\
\hline $\begin{array}{l}1 \text { Low-level waste must contribute to and not detract } \\
\text { from achieving long-term stability of the facility, } \\
\text { minimizing the need for long-term active maintenance, } \\
\text { minimizing subsidence, and minimizing contact of water } \\
\text { with waste. Void spaces within the waste and, if } \\
\text { containers are used, between the waste and its container } \\
\text { shall be reduced to the extent practical. }\end{array}$ & See (1) above. \\
\hline $\begin{array}{l}2 \text { Liquid low-level waste or low-level waste containing } \\
\text { free liquid must be converted into a form that contains as } \\
\text { little freestanding liquid as is reasonably achievable, but } \\
\text { in no case shall the liquid exceed } 1 \text { percent of the waste } \\
\text { volume when the low-level waste is in a disposal } \\
\text { container, or } 0.5 \text { percent of the waste volume after it is } \\
\text { processed to a stable form. }\end{array}$ & See (1) above. \\
\hline $\begin{array}{l}3 \text { Low-level waste must not be readily capable of } \\
\text { detonation or of explosive decomposition or reaction at } \\
\text { anticipated pressures and temperatures, or of explosive } \\
\text { reaction with water. Pyrophoric materials contained in } \\
\text { waste shall be treated, prepared, and packaged to be } \\
\text { nonflammable. }\end{array}$ & See (1) above. \\
\hline $\begin{array}{l}4 \text { Low-level waste must not contain, or be capable of } \\
\text { generating by radiolysis or biodegradation, quantities of } \\
\text { toxic gases, vapors, or fumes harmful to the public or } \\
\text { workers or disposal facility personnel, or harmful to the } \\
\text { long-term structural stability of the disposal site. }\end{array}$ & See (1) above. \\
\hline $\begin{array}{l}5 \text { Low-level waste in a gaseous form must be packaged } \\
\text { such that the pressure does not exceed } 1.5 \text { atmospheres } \\
\text { absolute at } 20 \mathrm{C} \text {. [ sic ] }\end{array}$ & See (1) above. \\
\hline $\begin{array}{l}\text { (e) The basis, procedures, and levels of authority } \\
\text { required for granting exceptions to the waste acceptance } \\
\text { requirements, which shall be contained in each facility's } \\
\text { waste acceptance documentation. Each exception request } \\
\text { shall be documented, including its disposition as } \\
\text { approved or not approved. }\end{array}$ & See (1) above. \\
\hline $\begin{array}{l}\text { From DOE G } 435.1-1 \text { Chapter IV: Waste acceptance } \\
\text { requirements are acceptable if they are documented and } \\
\text { contain a clear description of the procedure and bases for } \\
\text { obtaining an exception or deviation to the acceptance } \\
\text { criteria for low-level waste to be received at the facility. }\end{array}$ & \\
\hline $\begin{array}{l}\text { (2) Evaluation and Acceptance. The receiving facility } \\
\text { shall evaluate waste for acceptance, including } \\
\text { confirmation that the technical and administrative } \\
\text { requirements have been met. A process for the } \\
\text { disposition of non-conforming wastes shall be }\end{array}$ & See (1) above. \\
\hline
\end{tabular}


Table 3. (continued).

\begin{tabular}{|c|c|}
\hline \multicolumn{2}{|c|}{ Facility Name: CFA-637, Bunker } \\
\hline Chapter IV. Low-Level Waste Requirements & Facility Compliance Information \\
\hline established. & \\
\hline $\begin{array}{l}\text { From DOE G 435.1-1 Chapter IV: Compliance with the } \\
\text { waste acceptance requirements for a low-level waste } \\
\text { management facility is demonstrated if they include a } \\
\text { process for evaluation and acceptance of incoming waste } \\
\text { to ensure the acceptance criteria of the facility receiving } \\
\text { the waste are met that includes one of or a combination } \\
\text { of: (1) testing, sampling, and analysis of representative } \\
\text { samples of waste upon receipt; (2) testing, sampling, and } \\
\text { analysis of split samples of waste taken at the generator } \\
\text { site; (3) evaluation of testing, sampling, and analysis of } \\
\text { data provided by the generator, or (4) audits, reviews, } \\
\text { surveillance, or observations of generator waste } \\
\text { certification programs and characterization activities. } \\
\text { Additionally, acceptable waste acceptance requirements } \\
\text { for a storage, treatment or disposal facility will have } \\
\text { documented procedures and actions to be taken if a } \\
\text { waste that does not conform to the waste acceptance } \\
\text { criteria is received at the facility. }\end{array}$ & \\
\hline $\begin{array}{l}\text { H. Waste Generation Planning. The following } \\
\text { requirements are in addition to those in Chapter I of this } \\
\text { Manual [DOE M 435.1-1 §I.2.F(7)]. }\end{array}$ & $\begin{array}{l}\text { DOE Manual 435.1-1 §I.2.F(7) applies to field element } \\
\text { managers. }\end{array}$ \\
\hline $\begin{array}{l}\text { (1) Life-Cycle Planning. Prior to waste generation, } \\
\text { planning shall be performed to address the entire life } \\
\text { cycle for all low-level waste streams. }\end{array}$ & NA; this facility does not generate LLW. \\
\hline $\begin{array}{l}\text { From DOE G 435.1-1 Chapter IV: Compliance with this } \\
\text { planning requirement is demonstrated by the individual } \\
\text { sites establishing a process for evaluating the life-cycle } \\
\text { of low-level waste prior to its generation, including the } \\
\text { identification of low-level wastes with no path to } \\
\text { disposal and appropriate records justifying the newly } \\
\text { generated low-level waste stream(s), and site personnel } \\
\text { possessing planning information showing the location(s) } \\
\text { where low-level waste will be stored, treated, and/or } \\
\text { disposed along with a confirmation that the personnel } \\
\text { managing the facilities agree that the low-level waste } \\
\text { may be managed at those facilities. }\end{array}$ & \\
\hline $\begin{array}{l}\text { (2) Waste with No Identified Path to Disposal. Low-level } \\
\text { waste streams with no identified path to disposal shall be } \\
\text { generated only in accordance with approved conditions } \\
\text { which, at a minimum, shall address: }\end{array}$ & $\begin{array}{l}\text { This facility does not generate radioactive waste that does } \\
\text { not have an identified path to disposal. }\end{array}$ \\
\hline (a) Programmatic need to generate the waste; & See (2) above. \\
\hline $\begin{array}{l}\text { (b) Characteristics and issues preventing the disposal of } \\
\text { the waste; }\end{array}$ & See (2) above. \\
\hline $\begin{array}{l}\text { (c) Safe storage of the waste until disposal can be } \\
\text { achieved; and }\end{array}$ & See (2) above. \\
\hline (d) Activities and plans for achieving final disposal o & See (2) above. \\
\hline
\end{tabular}


Table 3. (continued).

\begin{tabular}{|c|c|}
\hline \multicolumn{2}{|c|}{ Facility Name: CFA-637, Bunker } \\
\hline Chapter IV. Low-Level Waste Requirements & Facility Compliance Information \\
\hline the waste. & \\
\hline $\begin{array}{l}\text { I. Waste Characterization. Low-level waste shall be } \\
\text { characterized using direct or indirect methods, and the } \\
\text { characterization documented in sufficient detail to ensure } \\
\text { safe management and compliance with the waste } \\
\text { acceptance requirements of the facility receiving the } \\
\text { waste. }\end{array}$ & $\begin{array}{l}\text { MCP-17000 } \S 4 \text { specifies the requirements for preparing } \\
\text { an IWTS profile that captures waste characterization } \\
\text { information. }\end{array}$ \\
\hline $\begin{array}{l}\text { From DOE G } 435.1-1 \text { Chapter IV: Compliance with this } \\
\text { requirement is demonstrated by a program for } \\
\text { documenting and the existence of records that document } \\
\text { the process for acquiring and verifying the validity of } \\
\text { low-level waste characterization data acquired through } \\
\text { the use of direct or indirect methods. }\end{array}$ & \\
\hline $\begin{array}{l}\text { (1) Data Quality Objectives. The data quality objectives } \\
\text { process, or a comparable process, shall be used for } \\
\text { identifying characterization parameters and acceptable } \\
\text { uncertainty in characterization data. }\end{array}$ & $\begin{array}{l}\text { Radioactive waste management facilities characterize } \\
\text { waste in accordance with the requirements of the } \\
\text { receiving storage, treatment, or disposal facility. The } \\
\text { documented use of a data quality objectives process, or }\end{array}$ \\
\hline $\begin{array}{l}\text { From DOE G } 435.1-1 \text { Chapter IV: Compliance with this } \\
\text { requirement is demonstrated by the documented use of a } \\
\text { data quality objectives or a comparable process for } \\
\text { determining the type, quantity, and quality of } \\
\text { characterization data needed to safely manage low-level } \\
\text { waste. }\end{array}$ & comparable process, was not identified for this tacility. \\
\hline $\begin{array}{l}\text { (2) Minimum Waste Characterization. Characterization } \\
\text { data shall, at a minimum, include the following } \\
\text { information relevant to the management of the waste: }\end{array}$ & $\begin{array}{l}\text { MCP- } 17000 \S 4 \text { specifies the requirements for preparing } \\
\text { an IWTS profile that captures waste characterization } \\
\text { information. }\end{array}$ \\
\hline $\begin{array}{l}\text { From DOE G } 435.1-1 \text { Chapter IV: Compliance with this } \\
\text { requirement is demonstrated by the existence of a } \\
\text { program or procedure for determining and records that } \\
\text { document characterization of low-level waste consistent } \\
\text { with the minimum characterization data requirements. }\end{array}$ & \\
\hline (a) Physical and chemical characteristics; & See (2) above. \\
\hline $\begin{array}{l}\text { (b) Volume, including the waste and any stabilization or } \\
\text { absorbent media; }\end{array}$ & See (2) above. \\
\hline (c) Weight of the container and contents; & See (2) above. \\
\hline $\begin{array}{l}\text { (d) Identities, activities, and concentrations of major } \\
\text { radionuclides; }\end{array}$ & See (2) above. \\
\hline (e) Characterization date; & See (2) above. \\
\hline (f) Generating source; and & See (2) above. \\
\hline $\begin{array}{l}\text { (g) Any other information which may be needed to } \\
\text { prepare and maintain the disposal facility performance } \\
\text { assessment, or demonstrate compliance with applicable } \\
\text { performance objectives. }\end{array}$ & See (2) above. \\
\hline J. Waste Certification. A waste certification program & MCP- $17000 \S 4$ specifies the requirements for preparing \\
\hline
\end{tabular}


Table 3. (continued).

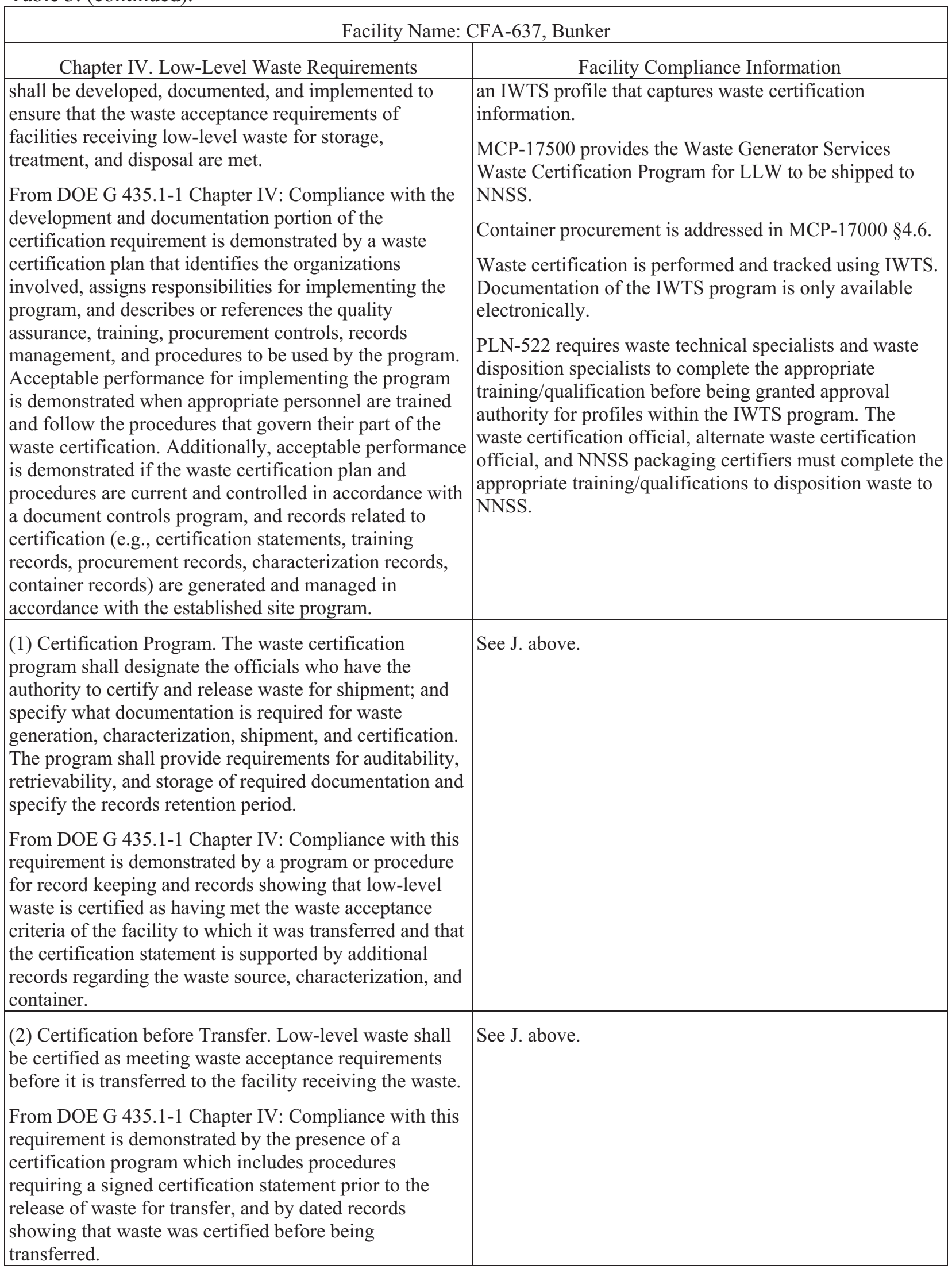


Table 3. (continued).

\begin{tabular}{|c|c|}
\hline \multicolumn{2}{|c|}{ Facility Name: CFA-637, Bunker } \\
\hline Chapter IV. Low-Level Waste Requirements & Facility Compliance Information \\
\hline $\begin{array}{l}\text { (3) Maintaining Certification. Low-level waste that has } \\
\text { been certified as meeting the waste acceptance } \\
\text { requirements for transfer to a storage, treatment, or } \\
\text { disposal facility shall be managed in a manner that } \\
\text { maintains its certification status. } \\
\text { From DOE G } 435.1-1 \text { Chapter IV: Compliance with this } \\
\text { requirement is demonstrated by a program or procedure } \\
\text { reflecting this requirement is present and site personnel } \\
\text { are able to show that the storage of low-level waste } \\
\text { containers is in a facility or manner where the containers } \\
\text { would not be damaged by normal weather events, and } \\
\text { cannot be accessed by unauthorized personnel. Further, } \\
\text { each container can be traced to its certification and the } \\
\text { information supporting that certification. }\end{array}$ & See J. above. \\
\hline $\begin{array}{l}\text { K. Waste Transfer. A documented process shall be } \\
\text { established and implemented for transferring } \\
\text { responsibility for management of low-level waste and for } \\
\text { ensuring availability of relevant data. The following } \\
\text { requirements are in addition to those in Chapter I of this } \\
\text { Manual. } \\
\text { From DOE G } 435.1-1 \text { Chapter IV: Compliance with this } \\
\text { requirement is demonstrated if facilities have procedures } \\
\text { for the receipt of waste and the transfer of waste, as } \\
\text { appropriate, which address the acquisition of waste and } \\
\text { container data and the transfer of ownership, } \\
\text { respectively. Further evidence of acceptable performance } \\
\text { is facility records showing that data on the waste } \\
\text { containers is available and accurate, and that documented } \\
\text { transfer of responsibility occurs. }\end{array}$ & $\begin{array}{l}\text { MCP-17000 specifies the requirements for preparing an } \\
\text { IWTS profile that captures waste certification data, } \\
\text { transfer information and associated authorizations. } \\
\text { MCP-17500 provides the Waste Generator Services } \\
\text { Waste Certification Program for LLW to be shipped to } \\
\text { NNSS. }\end{array}$ \\
\hline $\begin{array}{l}\text { (1) Authorization. Low-level waste shall not be } \\
\text { transferred to a storage, treatment, or disposal facility } \\
\text { until personnel responsible for the facility receiving the } \\
\text { waste authorize the transfer. } \\
\text { From DOE G } 435.1-1 \text { Chapter IV: Compliance with this } \\
\text { requirement is demonstrated by sites having procedures } \\
\text { that require a confirmation of authorization before } \\
\text { releasing waste for transfer, and records showing that } \\
\text { transfers are made in accordance with written } \\
\text { authorizations. }\end{array}$ & See K. above. \\
\hline $\begin{array}{l}\text { (2) Data. Waste characterization data, container } \\
\text { information, and generation, storage, treatment, and } \\
\text { transportation information for low-level waste shall be } \\
\text { transferred with or be traceable to the waste. } \\
\text { From DOE G } 435.1-1 \text { Chapter IV: Compliance with this } \\
\text { requirement is demonstrated if there are procedures } \\
\text { requiring that characterization and container data be } \\
\text { provided and maintained for each low-level waste }\end{array}$ & See K. above. \\
\hline
\end{tabular}


Table 3. (continued).

\begin{tabular}{|c|c|}
\hline \multicolumn{2}{|c|}{ Facility Name: CFA-637, Bunker } \\
\hline Chapter IV. Low-Level Waste Requirements & Facility Compliance Information \\
\hline $\begin{array}{l}\text { transfer and documented records of transfers show that } \\
\text { the information is being provided. }\end{array}$ & \\
\hline $\begin{array}{l}\text { L. Packaging and Transportation. The following } \\
\text { requirements are in addition to those in Chapter I of this } \\
\text { Manual [DOE M 435.1-1 §I.1.E(11)]. }\end{array}$ & $\begin{array}{l}\text { DOE Manual 435.1-1 §I.1.E(11) applies to field element } \\
\text { managers. }\end{array}$ \\
\hline (1) Packaging. If containers are used: & MCP-17000 $\S 4$ addresses packaging requirements. \\
\hline $\begin{array}{l}\text { From DOE G 435.1-1 Chapter IV: Compliance with the } \\
\text { packaging requirement is demonstrated by: (1) } \\
\text { procedures which document proper packaging protocols; } \\
\text { and (2) no trends of routine repackaging of low-level } \\
\text { waste that is packaged after issuance of DOE O } 435.1 \text {. } \\
\text { Successful performance of this requirement is also } \\
\text { demonstrated by a record of containers for which failure } \\
\text { has not routinely occurred under management } \\
\text { conditions. It is recognized that there may be failed } \\
\text { containers for waste previously placed in storage. For } \\
\text { those containers, the goal is to only have to repackage } \\
\text { the waste one time after it is retrieved and characterized. } \\
\text { Further, acceptable performance is demonstrated by } \\
\text { containers of waste having marking and labeling that } \\
\text { allows correlation with waste characterization data and } \\
\text { container information. }\end{array}$ & \\
\hline $\begin{array}{l}\text { (a) Low-level waste shall be packaged in a manner that } \\
\text { provides containment and protection for the duration of } \\
\text { the anticipated storage period and until disposal is } \\
\text { achieved or until the waste has been removed from the } \\
\text { container. }\end{array}$ & See (1) above. \\
\hline $\begin{array}{l}\text { (b) When waste is packaged, vents or other measures } \\
\text { shall be provided if the potential exists for pressurizing } \\
\text { or generating flammable or explosive concentrations of } \\
\text { gases within the waste container. }\end{array}$ & See (1) above. \\
\hline $\begin{array}{l}\text { (c) Containers of low-level waste shall be marked such } \\
\text { that their contents can be identified. }\end{array}$ & See (1) above. \\
\hline $\begin{array}{l}\text { (2) Transportation. To the extent practical, the volume of } \\
\text { waste and number of low-level waste shipments shall be } \\
\text { minimized. }\end{array}$ & $\begin{array}{l}\text { MCP- } 17000 \S 4 \text { addresses transportation. The waste } \\
\text { disposition specialist coordinates with packaging and } \\
\text { transportation personnel for waste shipped offsite from }\end{array}$ \\
\hline $\begin{array}{l}\text { From DOE G 435.1-1 Chapter IV: Compliance with this } \\
\text { requirement can be demonstrated by a combination of } \\
\text { site procedures directing the efficient use of waste } \\
\text { container capacity and documentation showing that low- } \\
\text { level waste shipments are systematically planned and } \\
\text { optimized to the extent practical. }\end{array}$ & $\begin{array}{l}\text { Waste is shipped directly to NNSS from this facility. } \\
\text { MCP-17500 specifies the waste certification official and } \\
\text { waste disposition specialist responsibilities and } \\
\text { coordination with packaging and transportation personnel. }\end{array}$ \\
\hline $\begin{array}{l}\text { M. Site Evaluation and Facility Design. The following } \\
\text { requirements are in addition to those in Chapter I of this } \\
\text { Manual. }\end{array}$ & $\begin{array}{l}\text { NA; this requirement addresses new radioactive waste } \\
\text { management facilities. }\end{array}$ \\
\hline (1) Site Evaluation. Proposed locations for low-ler & See M. above. \\
\hline
\end{tabular}


Table 3. (continued).

\begin{tabular}{|c|c|}
\hline \multicolumn{2}{|c|}{ Facility Name: CFA-637, Bunker } \\
\hline Chapter IV. Low-Level Waste Requirements & Facility Compliance Information \\
\hline $\begin{array}{l}\text { waste facilities shall be evaluated to identify relevant } \\
\text { features that should be avoided or must be considered in } \\
\text { facility design and analyses. }\end{array}$ & \\
\hline $\begin{array}{l}\text { (a) Each site proposed for a new low-level waste facility } \\
\text { or expansion of an existing low-level waste facility shall } \\
\text { be evaluated considering environmental characteristics, } \\
\text { geotechnical characteristics, and human activities, } \\
\text { including for a low-level waste disposal facility, the } \\
\text { capability of the site to demonstrate, at a minimum, } \\
\text { whether it is: }\end{array}$ & See M. above. \\
\hline $\begin{array}{l}1 \text { Located to accommodate the projected volume of } \\
\text { waste to be received; }\end{array}$ & See M. above. \\
\hline $\begin{array}{l}2 \text { Located in a flood plain, a tectonically active area, or } \\
\text { in the zone of water table fluctuation; and }\end{array}$ & See M. above. \\
\hline $\begin{array}{l}3 \text { Located where radionuclide migration pathways are } \\
\text { predictable and erosion and surface runoff can be } \\
\text { controlled. }\end{array}$ & See M. above. \\
\hline $\begin{array}{l}\text { (b) Proposed sites with environmental characteristics, } \\
\text { geotechnical characteristics, and human activities for } \\
\text { which adequate protection cannot be provided through } \\
\text { facility design shall be deemed unsuitable for the } \\
\text { location of the facility. }\end{array}$ & See M. above. \\
\hline $\begin{array}{l}\text { (c) Low-level waste disposal facilities shall be sited to } \\
\text { achieve long-term stability and to minimize, to the extent } \\
\text { practical, the need for active maintenance following final } \\
\text { closure. }\end{array}$ & See M. above. \\
\hline $\begin{array}{l}\text { (2) Low-Level Waste Treatment and Storage Facility } \\
\text { Design. The following facility requirements and general } \\
\text { design criteria, at a minimum, apply: }\end{array}$ & See M. above. \\
\hline $\begin{array}{l}\text { (a) Confinement. Low-level waste systems and } \\
\text { components shall be designed to maintain waste } \\
\text { confinement. }\end{array}$ & See M. above. \\
\hline (b) Ventilation. & See M. above. \\
\hline $\begin{array}{l}1 \text { Design of low-level waste treatment and storage } \\
\text { facilities shall include ventilation, if applicable, through } \\
\text { an appropriate filtration system to maintain the release of } \\
\text { radioactive material in airborne effluents within the } \\
\text { requirements and guidelines specified in applicable } \\
\text { requirements. }\end{array}$ & See M. above. \\
\hline $\begin{array}{l}2 \text { When conditions exist for generating gases in } \\
\text { flammable or explosive concentrations, ventilation } \\
\text { systems or other measures shall be provided to keep the } \\
\text { gases in a non-flammable and nonexplosive condition. } \\
\text { Where concentrations of explosive or flammable gases } \\
\text { are expected to approach the lower flammability limit, }\end{array}$ & See M. above. \\
\hline
\end{tabular}


Table 3. (continued).

\begin{tabular}{|c|c|}
\hline \multicolumn{2}{|c|}{ Facility Name: CFA-637, Bunker } \\
\hline Chapter IV. Low-Level Waste Requirements & Facility Compliance Information \\
\hline $\begin{array}{l}\text { measures shall be taken to prevent deflagration or } \\
\text { detonation. }\end{array}$ & \\
\hline $\begin{array}{l}\text { (c) Consideration of Decontamination and } \\
\text { Decommissioning. Areas in new and modifications to } \\
\text { existing low-level waste management facilities that are } \\
\text { subject to contamination with radioactive or other } \\
\text { hazardous materials shall be designed to facilitate } \\
\text { decontamination. For such facilities a proposed } \\
\text { decommissioning method or a conversion method } \\
\text { leading to reuse shall be described. }\end{array}$ & See M. above. \\
\hline $\begin{array}{l}\text { (d) Instrumentation and Control Systems. Engineering } \\
\text { controls shall be incorporated in the design and } \\
\text { engineering of low-level waste treatment and storage } \\
\text { facilities to provide volume inventory data and to prevent } \\
\text { spills, leaks, and overflows from tanks or confinement } \\
\text { systems. }\end{array}$ & See M. above. \\
\hline $\begin{array}{l}\text { (e) Monitoring. Monitoring and/or leak detection } \\
\text { capabilities shall be incorporated in the design and } \\
\text { engineering of low-level waste treatment and storage } \\
\text { facilities to provide rapid identification of failed } \\
\text { confinement and/or other abnormal conditions. }\end{array}$ & See M. above. \\
\hline $\begin{array}{l}\text { (3) Low-Level Waste Disposal Facility Design. The } \\
\text { following facility requirements and general design } \\
\text { criteria, at a minimum, apply: }\end{array}$ & See M. above. \\
\hline $\begin{array}{l}\text { (a) Confinement. Low-level waste systems and } \\
\text { components shall be designed to maintain waste } \\
\text { confinement. }\end{array}$ & See M. above. \\
\hline (b) Ventilation. & See M. above. \\
\hline $\begin{array}{l}1 \text { Design of low-level waste disposal facilities shall } \\
\text { include ventilation, if applicable, through an appropriate } \\
\text { filtration system to maintain the release of radioactive } \\
\text { material in airborne effluents within the requirements } \\
\text { and guidelines specified in applicable requirements. }\end{array}$ & See M. above. \\
\hline $\begin{array}{l}2 \text { When conditions exist for generating gases in } \\
\text { flammable or explosive concentrations, ventilation } \\
\text { systems or other measures shall be provided to keep the } \\
\text { gases in a nonflammable and non-explosive condition. } \\
\text { Where concentrations of explosive or flammable gases } \\
\text { are expected to approach the lower flammability limit, } \\
\text { measures shall be taken to prevent deflagration or } \\
\text { detonation. }\end{array}$ & See M. above. \\
\hline $\begin{array}{l}\text { (c) Stability. Low-level waste disposal facilities shall be } \\
\text { designed to achieve long-term stability and to minimize } \\
\text { to the extent practical, the need for active maintenance } \\
\text { following final closure. }\end{array}$ & See M. above. \\
\hline (d) Control of Water. Low-level waste disposal facilities & See M. above. \\
\hline
\end{tabular}


Table 3. (continued).

\begin{tabular}{|c|c|}
\hline \multicolumn{2}{|c|}{ Facility Name: CFA-637, Bunker } \\
\hline Chapter IV. Low-Level Waste Requirements & Facility Compliance Information \\
\hline $\begin{array}{l}\text { shall be designed to minimize to the extent practical, the } \\
\text { contact of waste with water during and after disposal. }\end{array}$ & \\
\hline $\begin{array}{l}\text { N. Storage and Staging. The following requirements are } \\
\text { in addition to those in Chapter I of this Manual [DOE M } \\
435.1-1 \text { §I.2.F(13)]. }\end{array}$ & $\begin{array}{l}\text { DOE Manual 435.1-1 §I.2.F(13) applies to field element } \\
\text { managers. }\end{array}$ \\
\hline $\begin{array}{l}\text { (1) Storage Prohibitions. Low-level waste in storage } \\
\text { shall not be readily capable of detonation, explosive } \\
\text { decomposition, reaction at anticipated pressures and } \\
\text { temperatures, or explosive reaction with water. Prior to } \\
\text { storage, pyrophoric materials shall be treated, prepared, } \\
\text { and packaged to be nonflammable. }\end{array}$ & NA; this facility does not store LLW. \\
\hline $\begin{array}{l}\text { From DOE G 435.1-1 Chapter IV: Compliance with this } \\
\text { requirement is demonstrated by having waste acceptance } \\
\text { requirements which prohibit low-level waste that is } \\
\text { ignitable or explosive from being accepted for storage } \\
\text { unless it has been treated, and procedures for properly } \\
\text { preparing such materials for safe storage. }\end{array}$ & \\
\hline $\begin{array}{l}\text { (2) Storage Limit. Low-level waste that has an identified } \\
\text { path to disposal shall not be stored longer than one year } \\
\text { prior to disposal, except for storage for decay, or as } \\
\text { otherwise authorized by the Field Element Manager. }\end{array}$ & $\begin{array}{l}\text { NA; this facility does not store LLW. See N. (7) below } \\
\text { for staging requirements. }\end{array}$ \\
\hline $\begin{array}{l}\text { From DOE G } 435.1-1 \text { Chapter IV: Storage longer than } \\
\text { one year can be justified if the conditions for such } \\
\text { storage are approved by the Field Element Manager as } \\
\text { part of the radioactive waste management basis for the } \\
\text { facility. }\end{array}$ & \\
\hline $\begin{array}{l}\text { Storage for radioactive decay for a period greater than } 1 \\
\text { year for waste that has an identified path to disposal is } \\
\text { allowed. Adequate justification and the supporting } \\
\text { information for storage for decay is to be documented in } \\
\text { the radioactive waste management basis for the facility } \\
\text { in which the storage will take place. }\end{array}$ & \\
\hline $\begin{array}{l}\text { Mixed waste. Under the Federal Facility Compliance Act } \\
\text { of 1992, DOE sites were required to develop Site } \\
\text { Treatment Plans to bring stored mixed low-level waste } \\
\text { into compliance with these requirements. The Site } \\
\text { Treatment Plan needs to be consulted and any mixed } \\
\text { low-level waste stored for the purpose of accumulation } \\
\text { to facilitate treatment must meet Resource Conservation } \\
\text { and Recovery Act storage requirements. There could be } \\
\text { several ways within different scenarios that this } \\
\text { requirement can be met, as illustrated by the examples } \\
\text { below, however, there are basically four ways to show } \\
\text { compliance with the requirement and include appropriate } \\
\text { provisions in the radioactive waste management basis for } \\
\text { the facility in which it is stored. }\end{array}$ & \\
\hline Legacy waste. As discussed above, the intention of the & \\
\hline
\end{tabular}


Table 3. (continued).

\begin{tabular}{|c|c|}
\hline \multicolumn{2}{|c|}{ Facility Name: CFA-637, Bunker } \\
\hline Chapter IV. Low-Level Waste Requirements & Facility Compliance Information \\
\hline $\begin{array}{l}\text { requirement is not to force malicious compliance or } \\
\text { heroic actions which would result in increased risk or } \\
\text { safety concerns. Rather, the intention is that waste in } \\
\text { storage longer than one year receives additional attention } \\
\text { to ensure that the public, the workers, and the } \\
\text { environment are protected from the hazards of the waste, } \\
\text { and that progress is being made to dispose of the waste. } \\
\text { There could be several ways within different scenarios } \\
\text { that this requirement can be met, as illustrated by the } \\
\text { examples below, however, there are basically four ways } \\
\text { to show compliance with the requirement: }\end{array}$ & \\
\hline $\begin{array}{l}\text { 1) the radioactive waste management basis allows for } \\
\text { storage for no more than one year. }\end{array}$ & \\
\hline $\begin{array}{l}\text { 2) the radioactive waste management basis allows for } \\
\text { storage for no more than one year, or for storage for } \\
\text { decay only for periods greater than a year, which are } \\
\text { specified on a radionuclide basis. }\end{array}$ & \\
\hline $\begin{array}{l}\text { 3) the radioactive waste management basis allows for } \\
\text { storage for more than one year, up to a specified period } \\
\text { of time based on a documented technical evaluation that } \\
\text { the waste can be stored in a manner that does not cause } \\
\text { changes to the waste or waste packages that is } \\
\text { detrimental to the safe storage of the waste, the final } \\
\text { disposal of the waste or to meeting the disposal } \\
\text { performance objectives. }\end{array}$ & \\
\hline $\begin{array}{l}\text { 4) the radioactive waste management basis allows for } \\
\text { storage for decay (with specifics) and for storage for } \\
\text { more than one year for other low-level waste, up to a } \\
\text { specified period of time based on a documented technical } \\
\text { evaluation that the waste can be stored in a manner that } \\
\text { does not cause changes to the waste or waste packages } \\
\text { that is detrimental to the safe storage of the waste, the } \\
\text { final disposal of the waste or to meeting the disposal } \\
\text { performance objectives. }\end{array}$ & \\
\hline $\begin{array}{l}\text { Compliance with this requirement is demonstrated by the } \\
\text { existence of a radioactive waste management basis for } \\
\text { the storage facility approved by the Field Element } \\
\text { Manager that includes the time frames that waste are } \\
\text { allowed to be stored, the necessary justifications for } \\
\text { storage for decay, and the necessary technical } \\
\text { evaluations if storage is to extend significantly beyond } \\
\text { the one-year time frame. }\end{array}$ & \\
\hline $\begin{array}{l}\text { (3) Storage Integrity. Low-level waste shall be stored in } \\
\text { a location and manner that protects the integrity of waste } \\
\text { for the expected time of storage and minimizes worker } \\
\text { exposure. }\end{array}$ & $\begin{array}{l}\text { NA; this facility does not store LLW. See N. (7) below } \\
\text { for staging requirements. }\end{array}$ \\
\hline $\begin{array}{l}\text { From DOE G } 435.1-1 \text { Chapter IV: However, in making a } \\
\text { decision to use a facility for storage and in developing a }\end{array}$ & \\
\hline
\end{tabular}


Table 3. (continued).

\begin{tabular}{|c|c|}
\hline \multicolumn{2}{|c|}{ Facility Name: CFA-637, Bunker } \\
\hline Chapter IV. Low-Level Waste Requirements & Facility Compliance Information \\
\hline $\begin{array}{l}\text { radioactive waste management basis for the activity, } \\
\text { particular attention to protection of workers is needed. }\end{array}$ & \\
\hline $\begin{array}{l}\text { Compliance with this requirement is demonstrated if } \\
\text { sites have storage capabilities for low-level waste that } \\
\text { provide protection to waste containers so that their } \\
\text { integrity will not be damaged through physical or } \\
\text { chemical (corrosion) processes and that keep personnel } \\
\text { from spending extended periods of time in the areas } \\
\text { where low-level waste is stored. }\end{array}$ & \\
\hline (4) Waste Characterization for Storage. & $\begin{array}{l}\text { NA; this facility does not store LLW. See N. (7) below } \\
\text { for staging requirements. }\end{array}$ \\
\hline $\begin{array}{l}\text { (a) Low-level waste that does not have an identified path } \\
\text { to disposal shall be characterized as necessary to meet } \\
\text { the data quality objectives and minimum characterization } \\
\text { requirements of this Chapter, to ensure safe storage, and } \\
\text { to facilitate disposal. }\end{array}$ & $\begin{array}{l}\text { NA; this facility does not store LLW. See N. (7) below } \\
\text { for staging requirements. }\end{array}$ \\
\hline $\begin{array}{l}\text { (b) Characterization information for all low-level waste } \\
\text { in storage shall be maintained as a record in accordance } \\
\text { with the requirements for Records Management in } \\
\text { Chapter I of this Manual. }\end{array}$ & $\begin{array}{l}\text { NA; this facility does not store LLW. See N. (7) below } \\
\text { for staging requirements. }\end{array}$ \\
\hline $\begin{array}{l}\text { From DOE G 435.1-1 Chapter IV: Compliance with this } \\
\text { requirement is demonstrated by documented procedures } \\
\text { for managing waste characterization and container } \\
\text { information on low-level waste as a Federal record. The } \\
\text { records are managed per the applicable policies and } \\
\text { procedures for records management referenced in DOE } \\
\text { O } 200.1 \text { and established at the applicable Field Element. }\end{array}$ & \\
\hline $\begin{array}{l}\text { (5) Container Inspection. A process shall be developed } \\
\text { and implemented for inspecting and maintaining } \\
\text { containers of low-level waste to ensure container } \\
\text { integrity is not compromised. }\end{array}$ & $\begin{array}{l}\text { LI-435 requires quarterly inspections of radioactive waste } \\
\text { containers if waste is stored outdoors or has been in } \\
\text { storage for greater than } 1 \text { year. }\end{array}$ \\
\hline $\begin{array}{l}\text { From DOE G 435.1-1 Chapter IV: Compliance with this } \\
\text { requirement is demonstrated by: (1) a documented } \\
\text { process for waste container inspection and maintenance; } \\
\text { and (2) documentation for all waste container inspections } \\
\text { and maintenance actions performed. }\end{array}$ & \\
\hline $\begin{array}{l}\text { (6) Storage Management. Low-level waste storage shall } \\
\text { be managed to identify and segregate low-level waste } \\
\text { from mixed low-level waste. }\end{array}$ & $\begin{array}{l}\text { NA; this facility does not store LLW. See N. (7) below } \\
\text { for staging requirements. }\end{array}$ \\
\hline $\begin{array}{l}\text { (7) Staging. Staging of low-level waste shall be for the } \\
\text { purpose of the accumulation of such quantities of waste } \\
\text { as necessary to facilitate transportation, treatment, and } \\
\text { disposal. Staging longer than } 90 \text { days shall meet the } \\
\text { requirements for storage above and in Chapter I of this } \\
\text { Manual. }\end{array}$ & $\begin{array}{l}\text { Routine LLW, such as personal protective equipment, is } \\
\text { accumulated at this facility for disposal. MCP-17000, } \\
\text { Appendix F, "Container Start Date and Storage } \\
\text { Prohibitions," restricts staging LLW to a 90-day } \\
\text { maximum at any generator or treatment facility prior to } \\
\text { acceptance by a storage facility. }\end{array}$ \\
\hline From DOE G 435.1-1 Chapter IV: The staging of low- & As stated in DOE Guide 435.1-1 §IV.N.(7), staging waste \\
\hline
\end{tabular}


Table 3. (continued).

\begin{tabular}{|c|c|}
\hline \multicolumn{2}{|c|}{ Facility Name: CFA-637, Bunker } \\
\hline Chapter IV. Low-Level Waste Requirements & Facility Compliance Information \\
\hline $\begin{array}{l}\text { level waste needs to be addressed in the radioactive } \\
\text { waste management basis for the facility that is } \\
\text { performing the staging. Generators, treatment facilities, } \\
\text { and disposal facilities that stage waste must ensure that } \\
\text { the action of staging is included and authorized as part of } \\
\text { their radioactive waste management basis for the } \\
\text { affected facilities, operations, or activities. }\end{array}$ & $\begin{array}{l}\text { in accordance with this requirement allows waste to be } \\
\text { accumulated without being considered storage and being } \\
\text { bound by the associated storage requirements. }\end{array}$ \\
\hline $\begin{array}{l}\text { Staging longer than } 90 \text { days must be justified, the } \\
\text { conditions for such storage met, and these practices } \\
\text { approved by the Field Element Manager as part of the } \\
\text { radioactive waste management basis for the facility. }\end{array}$ & \\
\hline $\begin{array}{l}\text { Compliance with this requirement is demonstrated by a } \\
\text { staging program that limits the temporary storage of } \\
\text { waste to only circumstances allowed in the requirement, } \\
\text { including justifications for any staging that exceeds the } \\
90 \text {-day period, which is documented in the radioactive } \\
\text { waste management basis for the facility. }\end{array}$ & \\
\hline $\begin{array}{l}\text { O. Treatment. Low-level waste treatment to provide } \\
\text { more stable waste forms and to improve the long-term } \\
\text { performance of a low-level waste disposal facility shall } \\
\text { be implemented as necessary to meet the performance } \\
\text { objectives of the disposal facility. }\end{array}$ & NA; this facility does not treat LLW. \\
\hline $\begin{array}{l}\text { From DOE G } 435.1-1 \text { Chapter IV: Compliance with this } \\
\text { requirement is demonstrated when a treatment facility or } \\
\text { process ensures that treated waste will meet the } \\
\text { minimum waste form requirements of DOE M } 435.1 \text { and } \\
\text { meet additional disposal facility-specific waste } \\
\text { acceptance requirements for additional stability or long- } \\
\text { term performance of facilities that will receive the } \\
\text { treated waste. }\end{array}$ & \\
\hline $\begin{array}{l}\text { P. Disposal. Low-level waste disposal facilities shall } \\
\text { meet the following requirements. }\end{array}$ & NA; this facility does not dispose of LLW. \\
\hline $\begin{array}{l}\text { (1) Performance Objectives. Low-level waste disposal } \\
\text { facilities shall be sited, designed, operated, maintained, } \\
\text { and closed so that a reasonable expectation exists that the } \\
\text { following performance objectives will be met for waste } \\
\text { disposed of after September 26, 1988: }\end{array}$ & See P. above. \\
\hline $\begin{array}{l}\text { (a) Dose to representative members of the public shall } \\
\text { not exceed } 25 \text { mrem }(0.25 \mathrm{mSv}) \text { in a year total effective } \\
\text { dose equivalent from all exposure pathways, excluding } \\
\text { the dose from radon and its progeny in air. }\end{array}$ & See P. above. \\
\hline $\begin{array}{l}\text { (b) Dose to representative members of the public via the } \\
\text { air pathway shall not exceed } 10 \mathrm{mrem}(0.10 \mathrm{mSv}) \text { in a } \\
\text { year total effective dose equivalent, excluding the dose } \\
\text { from radon and its progeny. }\end{array}$ & See P. above. \\
\hline $\begin{array}{l}\text { (c) Release of radon shall be less than an average flux of } \\
20 \mathrm{pCi} / \mathrm{m}^{2} / \mathrm{s}\left(0.74 \mathrm{~Bq} / \mathrm{m}^{2} / \mathrm{s}\right) \text { at the surface of the disposal }\end{array}$ & See P. above. \\
\hline
\end{tabular}


Table 3. (continued).

\begin{tabular}{|c|c|}
\hline \multicolumn{2}{|c|}{ Facility Name: CFA-637, Bunker } \\
\hline Chapter IV. Low-Level Waste Requirements & Facility Compliance Information \\
\hline $\begin{array}{l}\text { facility. Alternatively, a limit of } 0.5 \mathrm{pCi} / 1(0.0185 \mathrm{~Bq} / \mathrm{l}) \\
\text { of air may be applied at the boundary of the facility. }\end{array}$ & \\
\hline $\begin{array}{l}\text { (2) Performance Assessment. A site-specific radiological } \\
\text { performance assessment shall be prepared and } \\
\text { maintained for DOE low-level waste disposed of after } \\
\text { September } 26,1988 \text {. The performance assessment shall } \\
\text { include calculations for a } 1,000 \text { year period after closure } \\
\text { of potential doses to representative future members of } \\
\text { the public and potential releases from the facility to } \\
\text { provide a reasonable expectation that the performance } \\
\text { objectives identified in this Chapter are not exceeded as } \\
\text { a result of operation and closure of the facility. }\end{array}$ & See P. above. \\
\hline $\begin{array}{l}\text { (a) Analyses performed to demonstrate compliance with } \\
\text { the performance objectives in this Chapter, and to } \\
\text { establish limits on concentrations of radionuclides for } \\
\text { disposal based on the performance measures for } \\
\text { inadvertent intruders in this Chapter shall be based on } \\
\text { reasonable activities in the critical group of exposed } \\
\text { individuals. Unless otherwise specified, the assumption } \\
\text { of average living habits and exposure conditions in } \\
\text { representative critical groups of individuals projected to } \\
\text { receive the highest doses is appropriate. The likelihood } \\
\text { of inadvertent intruder scenarios may be considered in } \\
\text { interpreting the results of the analyses and establishing } \\
\text { radionuclide concentrations, if adequate justification is } \\
\text { provided. }\end{array}$ & See P. above. \\
\hline $\begin{array}{l}\text { (b) The point of compliance shall correspond to the point } \\
\text { of highest projected dose or concentration beyond a } 100 \\
\text { meter buffer zone surrounding the disposed waste. A } \\
\text { larger or smaller buffer zone may be used if adequate } \\
\text { justification is provided. }\end{array}$ & See P. above. \\
\hline $\begin{array}{l}\text { (c) Performance assessments shall address reasonably } \\
\text { foreseeable natural processes that might disrupt barriers } \\
\text { against release and transport of radioactive materials. }\end{array}$ & See P. above. \\
\hline $\begin{array}{l}\text { (d) Performance assessments shall use DOE-approved } \\
\text { dose coefficients (dose conversion factors) for internal } \\
\text { and external exposure of reference adults. }\end{array}$ & See P. above. \\
\hline $\begin{array}{l}\text { (e) The performance assessment shall include a } \\
\text { sensitivity/uncertainty analysis. }\end{array}$ & See P. above. \\
\hline $\begin{array}{l}\text { (f) Performance assessments shall include a } \\
\text { demonstration that projected releases of radionuclides to } \\
\text { the environment shall be maintained as low as } \\
\text { reasonably achievable (ALARA). }\end{array}$ & See P. above. \\
\hline $\begin{array}{l}\text { (g) For purposes of establishing limits on radionuclides } \\
\text { that may be disposed of near-surface, the performance } \\
\text { assessment shall include an assessment of impacts to } \\
\text { water resources. }\end{array}$ & See P. above. \\
\hline
\end{tabular}


Table 3. (continued).

\begin{tabular}{|c|c|}
\hline \multicolumn{2}{|c|}{ Facility Name: CFA-637, Bunker } \\
\hline Chapter IV. Low-Level Waste Requirements & Facility Compliance Information \\
\hline $\begin{array}{l}\text { (h) For purposes of establishing limits on the } \\
\text { concentration of radionuclides that may be disposed of } \\
\text { near-surface, the performance assessment shall include } \\
\text { an assessment of impacts calculated for a hypothetical } \\
\text { person assumed to inadvertently intrude for a temporary } \\
\text { period into the low-level waste disposal facility. For } \\
\text { intruder analyses, institutional controls shall be assumed } \\
\text { to be effective in deterring intrusion for at least } 100 \text { years } \\
\text { following closure. The intruder analyses shall use } \\
\text { performance measures for chronic and acute exposure } \\
\text { scenarios, respectively, of } 100 \text { mrem ( } 1 \mathrm{mSv} \text { ) in a year } \\
\text { and } 500 \text { mrem }(5 \mathrm{mSv}) \text { total effective dose equivalent } \\
\text { excluding radon in air. }\end{array}$ & See P. above. \\
\hline $\begin{array}{l}\text { (3) Composite Analysis. For disposal facilities which } \\
\text { received waste after September } 26,1988 \text {, a site-specific } \\
\text { radiological composite analysis shall be prepared and } \\
\text { maintained that accounts for all sources of radioactive } \\
\text { material that may be left at the DOE site and may } \\
\text { interact with the low- level waste disposal facility, } \\
\text { contributing to the dose projected to a hypothetical } \\
\text { member of the public from the existing or future disposal } \\
\text { facilities. Performance measures shall be consistent with } \\
\text { DOE requirements for protection of the public and } \\
\text { environment and evaluated for a } 1,000 \text { year period } \\
\text { following disposal facility closure. The composite } \\
\text { analysis results shall be used for planning, radiation } \\
\text { protection activities, and future use commitments to } \\
\text { minimize the likelihood that current low- level waste } \\
\text { disposal activities will result in the need for future } \\
\text { corrective or remedial actions to adequately protect the } \\
\text { public and the environment. }\end{array}$ & See P. above. \\
\hline $\begin{array}{l}\text { (4) Performance Assessment and Composite Analysis } \\
\text { Maintenance. The performance assessment and } \\
\text { composite analysis shall be maintained to evaluate } \\
\text { changes that could affect the performance, design, and } \\
\text { operating bases for the facility. Performance assessment } \\
\text { and composite analysis maintenance shall include the } \\
\text { conduct of research, field studies, and monitoring needed } \\
\text { to address uncertainties or gaps in existing data. The } \\
\text { performance assessment shall be updated to support the } \\
\text { final facility closure. Additional iterations of the } \\
\text { performance assessment and composite analysis shall be } \\
\text { conducted as necessary during the post-closure period. }\end{array}$ & See P. above. \\
\hline $\begin{array}{l}\text { (a) Performance assessments and composite analyses } \\
\text { shall be reviewed and revised when changes in waste } \\
\text { forms or containers, radionuclide inventories, facility } \\
\text { design and operations, closure concepts, or the improved } \\
\text { understanding of the performance of the waste disposal } \\
\text { facility in combination with the features of the site on }\end{array}$ & See P. above. \\
\hline
\end{tabular}


Table 3. (continued).

\begin{tabular}{|c|c|}
\hline \multicolumn{2}{|c|}{ Facility Name: CFA-637, Bunker } \\
\hline Chapter IV. Low-Level Waste Requirements & Facility Compliance Information \\
\hline $\begin{array}{l}\text { which it is located alter the conclusions or the conceptual } \\
\text { model(s) of the existing performance assessment or } \\
\text { composite analysis. }\end{array}$ & \\
\hline $\begin{array}{l}\text { (b) A determination of the continued adequacy of the } \\
\text { performance assessment and composite analysis shall be } \\
\text { made on an annual basis, and shall consider the results of } \\
\text { data collection and analysis from research, field studies, } \\
\text { and monitoring. }\end{array}$ & See P. above. \\
\hline $\begin{array}{l}\text { (c) Annual summaries of low-level waste disposal } \\
\text { operations shall be prepared with respect to the } \\
\text { conclusions and recommendations of the performance } \\
\text { assessment and composite analysis and a determination } \\
\text { of the need to revise the performance assessment or } \\
\text { composite analysis. }\end{array}$ & See P. above. \\
\hline $\begin{array}{l}\text { (5) Disposal Authorization. A disposal authorization } \\
\text { statement shall be obtained prior to construction of a new } \\
\text { low-level waste disposal facility. Field Elements with } \\
\text { existing low-level waste disposal facilities shall obtain a } \\
\text { disposal authorization statement in accordance with the } \\
\text { schedule in the Complex-Wide Low-Level Waste } \\
\text { Management Program Plan. The disposal authorization } \\
\text { statement shall be issued based on a review of the } \\
\text { facility's performance assessment, composite analysis, } \\
\text { performance assessment and composite analysis } \\
\text { maintenance, preliminary closure plan, and preliminary } \\
\text { monitoring plan. The disposal authorization statement } \\
\text { shall specify the limits and conditions on construction, } \\
\text { design, operations, and closure of the low-level waste } \\
\text { facility based on these reviews. A disposal authorization } \\
\text { statement is a part of the radioactive waste management } \\
\text { basis for a disposal facility. Failure to obtain a disposal } \\
\text { authorization statement by the implementation date of } \\
\text { this Order shall result in shutdown of the disposal } \\
\text { facility. }\end{array}$ & See P. above. \\
\hline $\begin{array}{l}\text { (6) Disposal Facility Operations. The disposal facility } \\
\text { design and operation must be consistent with the disposal } \\
\text { facility closure plan and lead to disposal facility closure } \\
\text { that provides a reasonable expectation that performance } \\
\text { objectives will be met. Low-level waste shall be } \\
\text { disposed in such a manner that achieves the performance } \\
\text { objectives stated in this Chapter, consistent with the } \\
\text { disposal facility radiological performance assessment. } \\
\text { Additional requirements include: }\end{array}$ & See P. above. \\
\hline $\begin{array}{l}\text { (a) Operating procedures shall be developed and } \\
\text { implemented for low-level waste disposal facilities that } \\
\text { protect the public, workers, and the environment; ensure } \\
\text { the security of the facility; minimize subsidence during } \\
\text { and after waste emplacement; achieve long-term stability } \\
\text { and minimize the need for long-term active maintenance; }\end{array}$ & See P. above. \\
\hline
\end{tabular}


Table 3. (continued).

\begin{tabular}{|c|c|}
\hline \multicolumn{2}{|c|}{ Facility Name: CFA-637, Bunker } \\
\hline Chapter IV. Low-Level Waste Requirements & Facility Compliance Information \\
\hline $\begin{array}{l}\text { and meet the requirements of the closure/post-closure } \\
\text { plan. }\end{array}$ & \\
\hline $\begin{array}{l}\text { (b) Permanent identification markers for disposal } \\
\text { excavations and monitoring wells shall be emplaced. }\end{array}$ & See P. above. \\
\hline $\begin{array}{l}\text { (c) Low-level waste placement into disposal units shall } \\
\text { minimize voids between waste containers. Voids within } \\
\text { disposal units shall be filled to the extent practical. } \\
\text { Uncontainerized bulk waste shall also be placed in a } \\
\text { manner that minimizes voids and subsidence. }\end{array}$ & See P. above. \\
\hline $\begin{array}{l}\text { (d) Operations are to be conducted so that active waste } \\
\text { disposal operations will not have an adverse effect on } \\
\text { any other disposal units. }\end{array}$ & See P. above. \\
\hline $\begin{array}{l}\text { (e) Operations shall include a process for tracking and } \\
\text { documenting low-level waste placement in the facility by } \\
\text { generator source. }\end{array}$ & See P. above. \\
\hline $\begin{array}{l}\text { (7) Alternate Requirements for Low-Level Waste } \\
\text { Disposal Facility Design and Operation. Requirements } \\
\text { other than those set forth in this Section for the design } \\
\text { and operation of a low-level waste disposal facility may } \\
\text { be approved on a specific basis if a reasonable } \\
\text { expectation is demonstrated that the disposal } \\
\text { performance objectives will be met. }\end{array}$ & See P. above. \\
\hline $\begin{array}{l}\text { Q. Closure. The following requirements are in addition } \\
\text { to those in Chapter I of this Manual. }\end{array}$ & NA; this facility does not dispose of LLW. \\
\hline $\begin{array}{l}\text { (1) Disposal Facility Closure Plans. A preliminary } \\
\text { closure plan shall be developed and submitted to } \\
\text { Headquarters for review with the performance } \\
\text { assessment and composite analysis. The closure plan } \\
\text { shall be updated following issuance of the disposal } \\
\text { authorization statement to incorporate conditions } \\
\text { specified in the disposal authorization statement. Closure } \\
\text { plans shall: }\end{array}$ & See Q. above. \\
\hline $\begin{array}{l}\text { (a) Be updated as required during the operational life of } \\
\text { the facility. }\end{array}$ & See Q. above. \\
\hline $\begin{array}{l}\text { (b) Include a description of how the disposal facility will } \\
\text { be closed to achieve long-term stability and minimize the } \\
\text { need for active maintenance following closure and to } \\
\text { ensure compliance with the requirements of DOE } \\
5400.5 \text {, Radiation Protection of the Public and the } \\
\text { Environment. }\end{array}$ & See Q. above. \\
\hline $\begin{array}{l}\text { (c) Include the total expected inventory of wastes to be } \\
\text { disposed of at the facility over the operational life of the } \\
\text { facility. }\end{array}$ & See Q. above. \\
\hline $\begin{array}{l}\text { (2) Disposal Facility Closure. Closure of a disposal } \\
\text { facility shall occur within a five-year period after it is }\end{array}$ & See Q. above. \\
\hline
\end{tabular}


Table 3. (continued).

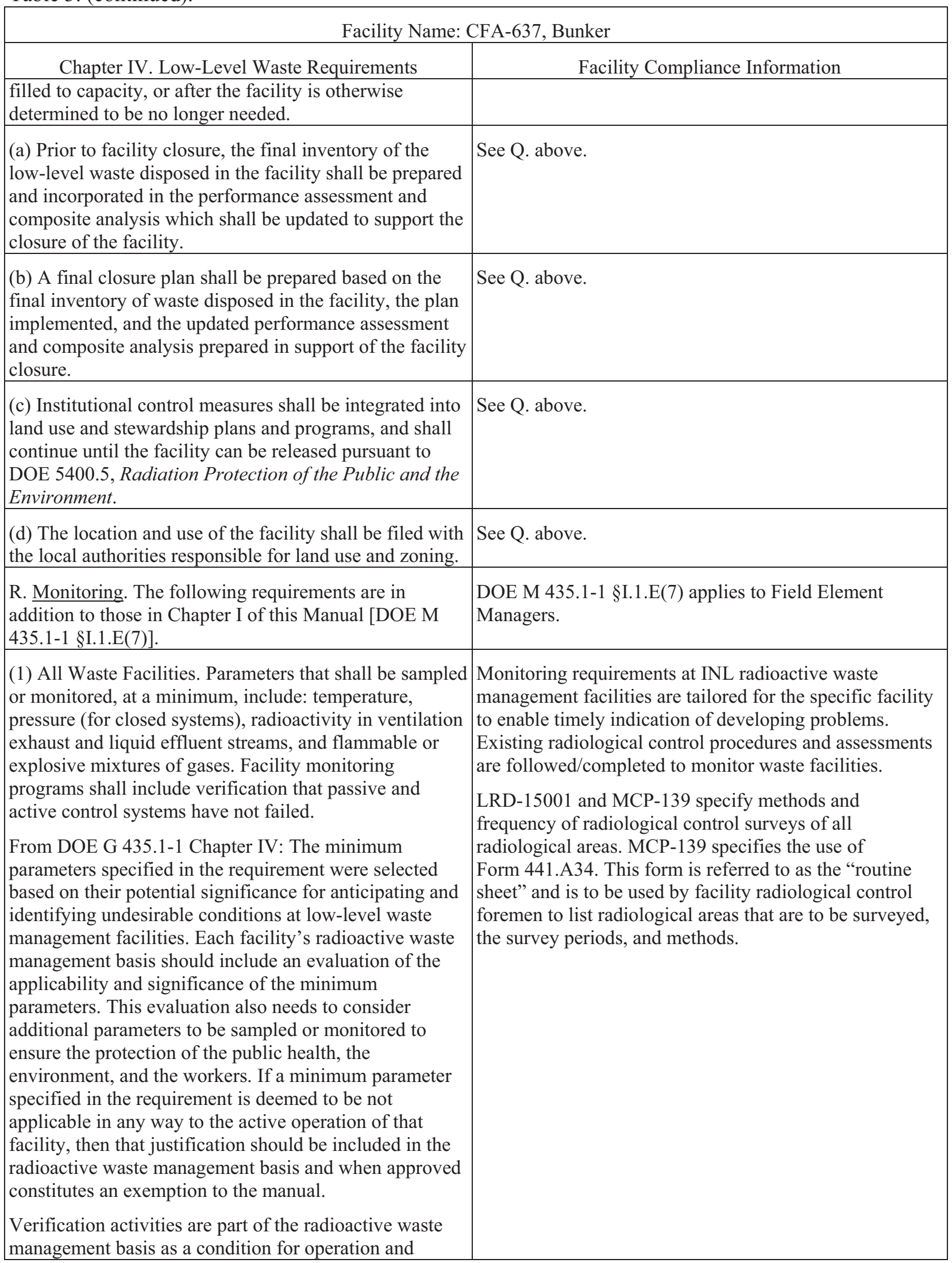


Table 3. (continued).

\begin{tabular}{|c|c|}
\hline \multicolumn{2}{|c|}{ Facility Name: CFA-637, Bunker } \\
\hline Chapter IV. Low-Level Waste Requirements & Facility Compliance Information \\
\hline documented appropriately. & \\
\hline $\begin{array}{l}\text { Compliance with this requirement is demonstrated if } \\
\text { monitoring or sampling for the stated parameters is } \\
\text { performed for all facilities with a precision, accuracy, } \\
\text { and frequency consistent with timely identification of } \\
\text { developing problems and a justification exists in the } \\
\text { approved radioactive waste management basis for those } \\
\text { specified parameters which are not monitored or } \\
\text { sampled. }\end{array}$ & \\
\hline $\begin{array}{l}\text { (2) Liquid Waste Storage Facilities. For facilities storing } \\
\text { liquid low-level waste, the following shall also be } \\
\text { monitored: liquid level and/or waste volume, and } \\
\text { significant waste chemistry parameters. }\end{array}$ & NA; liquid LLW is not stored in this facility. \\
\hline $\begin{array}{l}\text { (3) Disposal Facilities. A preliminary monitoring plan } \\
\text { for a low-level waste disposal facility shall be prepared } \\
\text { and submitted to Headquarters for review with the } \\
\text { performance assessment and composite analysis. The } \\
\text { monitoring plan shall be updated within one year } \\
\text { following issuance of the disposal authorization } \\
\text { statement to incorporate and implement conditions } \\
\text { specified in the disposal authorization statement. }\end{array}$ & NA; this facility does not dispose of LLW. \\
\hline $\begin{array}{l}\text { (a) The site-specific performance assessment and } \\
\text { composite analysis shall be used to determine the media, } \\
\text { locations, radionuclides, and other substances to be } \\
\text { monitored. }\end{array}$ & See (3) above. \\
\hline $\begin{array}{l}\text { (b) The environmental monitoring program shall be } \\
\text { designed to include measuring and evaluating releases, } \\
\text { migration of radionuclides, disposal unit subsidence, and } \\
\text { changes in disposal facility and disposal site parameters } \\
\text { which may affect long-term performance. }\end{array}$ & See (3) above. \\
\hline $\begin{array}{l}\text { (c) The environmental monitoring programs shall be } \\
\text { capable of detecting changing trends in performance to } \\
\text { allow application of any necessary corrective action prior } \\
\text { to exceeding the performance objectives in this Chapter. }\end{array}$ & See (3) above. \\
\hline
\end{tabular}

\subsection{CFA-690, Radiological and Environmental Sciences Laboratory}

1. Facility description: RESL routinely performs chemical and radiochemical separations and instrumental analysis on water and soil samples, and has the capability to analyze, as requested, other types of media such as vegetation and biological samples (e.g., urine and feces). The Mixed Analyte Performance Evaluation Program prepares performance standards containing low levels of radioactivity and hazardous materials. The DOE Laboratory Accreditation Program prepares radioactive standards and phantoms for performance test evaluations. The DOE Laboratory Accreditation Program staff also utilizes radioactive check sources and phantoms for quality control purposes. 
RDR provides and processes personnel whole body and extremity dosimetry, environmental dosimetry, and dosimetry for nuclear accidents. RDR also operates a whole-body counter and a lung counter at CFA-690. Radioactive check sources, or phantoms loaded with radioactive sources, are used for quality control purposes.

U.S. Geological Survey maintains offices and storage space in CFA-690. Water samples are prepared prior to analysis by adding small amounts of acid. Also, U.S. Geological Survey radioactive sources (licensed by the Nuclear Regulatory Commission) are used and stored in CFA-690.

2. Hazard category: LTHC3 radiological

3. Radioactive waste managed at this facility: Routine contact-handled LLW and mixed LLW is generated and staged at this facility.

4. RWMB documents/programs:

a) Safety basis/hazard analysis:

- "Radiological and Environmental Sciences Laboratory Safety Analysis Document for CFA690 and CFA-676"

b) Laboratory-wide:

- Form 441.A34, "INL Radiological Control Required Surveys"

- LI-435, "Waste Management Routine Field Activities"

- LRD-15001, "Radiological Control Manual"

- LWP-8000, "Environmental Instructions for Facilities, Processes, Materials and Equipment"

- LWP-13840, "Management of Issues, Observations, and Noteworthy Practices"

- LWP-14002, "Timeout and Stop Work Authority"

- LWP-15011, "Radioactive Material Areas and Radioactive Storage Areas"

- LWP-17000, "Waste Management"

- MCP-139, "Radiological Surveys"

- MCP-17000, "Waste Generator Services Waste Management"

- MCP-17410, "Management of Waste Storage Areas"

- MCP-17500, "Waste Generator Services Certification of Waste Shipments to the Nevada Test Site"

- PDD-17000, "Waste Management Program"

- PLN-114, "INL Emergency Plan/RCRA Contingency Plan"

- PLN-522, "Quality Assurance Program Plan for the Waste Management/Waste Certification Program"

c) Facility-specific:

- RESL-AP-10, "Waste Management."

LLW is managed at this facility. Table 4 presents the facility compliance information for Chapter IV, "Low-level Waste Requirements." 
Table 4. CFA-690, Radiological and Environmental Sciences Laboratory, DOE Manual 435.1-1 low-level waste requirements and facility compliance information.

\begin{tabular}{|c|c|}
\hline \multicolumn{2}{|c|}{ Facility Name: CFA-690, Radiological and Environmental Science Laboratory } \\
\hline Chapter IV. Low-Level Waste Requirements & Facility Compliance Information \\
\hline $\begin{array}{l}\text { A. Definition of Low-Level Waste. Low-level } \\
\text { radioactive waste is radioactive waste that is not high- } \\
\text { level radioactive waste, spent nuclear fuel, transuranic } \\
\text { waste, byproduct material (as defined in section 11e.(2) } \\
\text { of the Atomic Energy Act of 1954, as amended), or } \\
\text { naturally occurring radioactive material. } \\
\text { (From DOE G } 435.1-1 \text { Chapter IV: Low-level } \\
\text { radioactive waste is defined by what it is not. The } \\
\text { guidance on definitions in Chapters II and III should be } \\
\text { consulted first for making a determination on how to } \\
\text { properly manage a suspect waste stream.) }\end{array}$ & $\begin{array}{l}\text { This requirement provides the criteria for determining } \\
\text { which DOE radioactive waste is to be managed as LLW } \\
\text { in accordance with DOE Manual } 435.1-1 \text {, Chapter IV. } \\
\text { Radioactive waste managed at this facility under the } \\
\text { requirements of this chapter is not managed under the } \\
\text { requirements of DOE Manual } 435.1-1 \text { Chapter II or } \\
\text { Chapter III. }\end{array}$ \\
\hline $\begin{array}{l}\text { B. Management of Specific Wastes. The following } \\
\text { provide for management of specific wastes as low-level } \\
\text { waste in accordance with the requirements in this } \\
\text { Chapter: }\end{array}$ & See (1), (2), (3), (4) below. \\
\hline $\begin{array}{l}\text { (1) Mixed Low-Level Waste. Low-level waste } \\
\text { determined to contain both source, special nuclear, or } \\
\text { byproduct material subject to the Atomic Energy Act of } \\
1954 \text {, as amended, and a hazardous component subject to } \\
\text { the Resource Conservation and Recovery Act (RCRA), } \\
\text { as amended, shall be managed in accordance with the } \\
\text { requirements of RCRA and DOE O } 435.1 \text {, Radioactive } \\
\text { Waste Management, and this Manual. }\end{array}$ & $\begin{array}{l}\text { This facility manages mixed LLW in SAAs. Management } \\
\text { of SAAs is addressed in MCP-17400 and overall } \\
\text { management of mixed waste is addressed in MCP-17000. }\end{array}$ \\
\hline $\begin{array}{l}\text { (2) TSCA-Regulated Waste. Low-level waste containing } \\
\text { polychlorinated biphenyls, asbestos, or other such } \\
\text { regulated toxic components shall be managed in } \\
\text { accordance with requirements derived from the Toxic } \\
\text { Substances Control Act, as amended, DOE O } 435.1 \text {, } \\
\text { Radioactive Waste Management, and this Manual. }\end{array}$ & NA; this facility does not manage TSCA-regulated waste. \\
\hline $\begin{array}{l}\text { (3) Accelerator-Produced Waste. Radioactive waste } \\
\text { produced as a result of operations of DOE accelerators is } \\
\text { low-level waste and shall be managed in accordance with } \\
\text { DOE O 435.1, Radioactive Waste Management, and this } \\
\text { Manual, and all applicable Federal or State requirements. }\end{array}$ & $\begin{array}{l}\text { NA; this facility does not manage accelerator-produced } \\
\text { waste. }\end{array}$ \\
\hline $\begin{array}{l}\text { (4) } 11 \text { e.(2) and Naturally Occurring Radioactive } \\
\text { Material. Small quantities of } 11 \text { e.(2) byproduct material } \\
\text { and naturally occurring radioactive material may be } \\
\text { managed as low-level waste provided they can be } \\
\text { managed to meet the requirements for low-level waste } \\
\text { disposal in Section IV.P of this Manual. }\end{array}$ & $\begin{array}{l}\text { NA; this facility does not manage naturally occurring } \\
\text { radioactive material. }\end{array}$ \\
\hline $\begin{array}{l}\text { C. Complex-Wide Low-Level Waste Management } \\
\text { Program. A complex-wide program and plan shall be } \\
\text { developed as described under Responsibilities, 2.B and } \\
\text { 2.D, in Chapter I of this Manual. }\end{array}$ & $\begin{array}{l}\text { Not a facility-specific requirement. DOE Manual 435.1-1 } \\
\text { §I.2.B and } \S I .2 . D \text { apply to the Assistant Secretary for } \\
\text { Environmental Management and the Deputy Assistant } \\
\text { Secretary for Waste Management, respectively. }\end{array}$ \\
\hline D. Radioactive Waste Management Basis. Low-level & The RWMB for the facility is in development. This table \\
\hline
\end{tabular}


Table 4. (continued).

Facility Name: CFA-690, Radiological and Environmental Science Laboratory

Chapter IV. Low-Level Waste Requirements

waste facilities, operations, and activities shall have a radioactive waste management basis consisting of physical and administrative controls to ensure the protection of workers, the public, and the environment. The following specific waste management controls shall be part of the radioactive waste management basis:

(1) Generators. The waste certification program.

From DOE G 435.1-1 Chapter IV: For a facility that generates low-level waste, the radioactive waste management basis is to include the program for certifying that waste meets the waste acceptance requirements of the facility(ies) to which the waste will be sent.

(2) Treatment Facilities. certification program. The waste acceptance requirements and the waste [sic]

From DOE G 435.1-1 Chapter IV: Facilities that store or treat low-level waste are to have approved waste acceptance requirements (see DOE M 435.1-1, Section IV.G) prior to the issuance of a radioactive waste management basis.

A facility that stores or treats waste also is generally expected to have a waste certification program. Waste from these facilities will have to be certified as meeting the waste acceptance requirements of the facility to which it will be transferred, and the facilities have the potential for generating radioactive waste (e.g., secondary processing streams from treatment, monitoring and sampling, radioactive release cleanup). Consequently, storage and treatment facilities should also have an approved waste certification program as part of their radioactive waste management basis.

As part of the radioactive waste management basis, site personnel needs to implement a system or process for tracking the waste inventory at a storage, treatment, or disposal facility.

(3) Storage Facilities. The waste acceptance requirements and the waste certification program.

From DOE G 435.1-1 Chapter IV: Facilities that store or treat low-level waste are to have approved waste acceptance requirements (see DOE M 435.1-1, Section IV.G) prior to the issuance of a radioactive waste management basis.

A facility that stores or treats waste also is generally expected to have a waste certification program. Waste from these facilities will have to be certified as meeting the waste acceptance requirements of the facility to which it will be transferred, and the facilities have the
Facility Compliance Information

is being prepared as a tool for developing the RWMB.

See J. below for waste certification program requirements.

"Radiological and Environmental Sciences Laboratory Safety Analysis Document for CFA-690 and CFA-676," establishes this laboratory facility as an LTHC3 facility.

NA; waste is not treated at this facility.

Containerized elementary neutralization is performed at this facility as provided by LWP-8000. As stated in $\S 4.118$, elementary neutralization of corrosive hazardous waste may take place at any location at which the waste is generated or stored and neither a generator treatment plan nor a permit is required. Solidification of liquid LLW for the purpose of staging (not for treating the radioactive constituents) also may be performed. Therefore, this facility is not considered to be a treatment facility.

NA; this facility stages waste in accordance with N.(7) to facilitate treatment or disposal. 
Table 4. (continued).

Facility Name: CFA-690, Radiological and Environmental Science Laboratory

\begin{tabular}{|c|}
\hline Chapter IV. Low-Level Waste Requirements \\
\hline $\begin{array}{l}\text { potential for generating radioactive waste (e.g., } \\
\text { secondary processing streams from treatment, } \\
\text { monitoring and sampling, radioactive release cleanup). } \\
\text { Consequently, storage and treatment facilities should } \\
\text { also have an approved waste certification program as } \\
\text { part of their radioactive waste management basis. }\end{array}$ \\
\hline $\begin{array}{l}\text { As part of the radioactive waste management basis, site } \\
\text { personnel needs to implement a system or process for } \\
\text { tracking the waste inventory at a storage, treatment, or } \\
\text { disposal facility. }\end{array}$ \\
\hline $\begin{array}{l}\text { (4) Disposal Facilities. The performance assessment, } \\
\text { composite analysis, disposal authorization statement, } \\
\text { closure plan, waste acceptance requirements, and } \\
\text { monitoring plan. }\end{array}$ \\
\hline $\begin{array}{l}\text { E. Contingency Actions. The following requirements ar } \\
\text { in addition to those in Chapter I of this Manual [DOE N } \\
435.1-1 \text { §I.1.E(5)]. }\end{array}$ \\
\hline
\end{tabular}

(1) Contingency Storage. For off-normal or emergency situations involving high activity or high hazard liquid low-level waste storage or treatment, spare capacity with adequate capabilities shall be maintained to receive the largest volume of liquid contained in any one storage tank or treatment facility. Tanks or other facilities that are designated low-level waste contingency storage shall be maintained in an operational condition when waste is present and shall meet the requirements of DOE O 435.1, Radioactive Waste Management, and this Manual.

From DOE G 435.1-1 Chapter IV: Compliance with these requirements is demonstrated if adequate spare capacity and transfer equipment exists for emergency transfers of all high activity and high hazard liquid lowlevel waste. In addition, the capability to perform emergency transfers is demonstrated by having waste transfer routings identified, operational procedures to direct transfers, staff trained to the procedures, and records showing that the spare capacity and transfer capability are kept in operating condition.

(2) Transfer Equipment. Pipelines and auxiliary facilities NA; this facility does not store or treat liquid LLW. necessary for the transfer of high activity or high hazard liquid low-level waste to contingency storage shall be maintained in an operational condition when waste is present and shall meet the requirements of DOE O 435.1, Radioactive Waste Management, and this Manual.

From DOE G 435.1-1 Chapter IV: Compliance with these requirements is demonstrated if adequate spare capacity and transfer equipment exists for emergency transfers of all high activity and high hazard liquid lowlevel waste. In addition, the capability to perform

NA; this facility is not a disposal facility.

DOE Manual 435.1-1 §I.1.E(5) addresses the sitewide emergency management system. The INL plan is provided in PLN-114.

NA; this facility does not store liquid LLW.

\section{NA;} (1)

,


Table 4. (continued).

Facility Name: CFA-690, Radiological and Environmental Science Laboratory

\begin{tabular}{|c|c|}
\hline Chapter IV. Low-Level Waste Requirements & Facility Compliance Information \\
\hline $\begin{array}{l}\text { emergency transfers is demonstrated by having waste } \\
\text { transfer routings identified, operational procedures to } \\
\text { direct transfers, staff trained to the procedures, and } \\
\text { records showing that the spare capacity and transfer } \\
\text { capability are kept in operating condition. }\end{array}$ & \\
\hline \multirow{4}{*}{$\begin{array}{l}\text { F. Corrective Actions. I of this Manual. The following } \\
\text { requirements are in addition to those in Chapter [sic] } \\
\text { From DOE G 435.1-1 Chapter IV: Compliance with } \\
\text { DOE M 435.1-1 §I.2.G.(1) is demonstrated by records } \\
\text { showing what corrective actions were taken to remedy } \\
\text { situations in the radioactive waste management system. } \\
\text { Compliance with DOE M 435.1-1 §I.2.G.(2) is } \\
\text { demonstrated by having the necessary procedures, } \\
\text { mechanisms, and training in place to effect shutdown or } \\
\text { curtailment of activities which pose an imminent danger } \\
\text { or other serious hazard to workers or the public, or are } \\
\text { not protective of the environment. }\end{array}$} & \multirow{4}{*}{$\begin{array}{l}\text { The INL-wide procedure addressing problem } \\
\text { identification as required by DOE Manual 435.1-1 } \\
\text { §I.2.G.(1) is LWP-13840, which implements the } \\
\text { laboratory's corrective action system. } \\
\text { The INL-wide procedure addressing shutdown or } \\
\text { curtailment of activities as required by DOE Manual } \\
\text { 435.1-1 §I.2.G.(2) is LWP-14002. }\end{array}$} \\
\hline & \\
\hline & \\
\hline & \\
\hline $\begin{array}{l}\text { (1) Order Compliance. Corrective actions shall be } \\
\text { implemented whenever necessary to ensure the } \\
\text { requirements of DOE O } 435.1 \text {, Radioactive Waste } \\
\text { Management, and this Manual are met. }\end{array}$ & \multirow[t]{3}{*}{ See F. above. } \\
\hline $\begin{array}{l}\text { From DOE G } 435.1-1 \text { Chapter IV: If a facility or activity } \\
\text { can be allowed to operate while a noncompliant or } \\
\text { hazardous condition exists, the allowance and any } \\
\text { associated limitations must be defined as part of the } \\
\text { facility or activity's radioactive waste management basis, } \\
\text { identified as a configuration controlled item in a } \\
\text { configuration management plan or included in a revision } \\
\text { or modification to an operating procedure or similar } \\
\text { controlled documentation. }\end{array}$ & \\
\hline $\begin{array}{l}\text { Compliance with this requirement is demonstrated if a } \\
\text { corrective action system addresses noncompliant or } \\
\text { hazardous situations involving low-level waste } \\
\text { management facilities in a systematic fashion, and allows } \\
\text { identification of problems by all personnel. }\end{array}$ & \\
\hline $\begin{array}{l}\text { (2) Operations Curtailment. Operations shall be curtailed } \\
\text { or facilities shut down for failure to establish, maintain, } \\
\text { or operate consistent with an approved radioactive waste } \\
\text { management basis. }\end{array}$ & \multirow[t]{2}{*}{$\begin{array}{l}\text { The approved RWMB establishes the current compliance } \\
\text { status at each radioactive waste management facility. } \\
\text { Facility assessments are scheduled to ensure waste } \\
\text { management activities are conducted in accordance with } \\
\text { the approved RWMB. }\end{array}$} \\
\hline $\begin{array}{l}\text { From DOE G 435.1-1 Chapter IV: Compliance with this } \\
\text { requirement is demonstrated with a documented system } \\
\text { of routine assessments to determine whether waste } \\
\text { management activities and facilities are operating in } \\
\text { accordance with an approved radioactive waste } \\
\text { management basis that provides for graded limitations } \\
\text { that can be placed on activities and operations that do not } \\
\text { have, or are operating outside of, an approved }\end{array}$ & \\
\hline
\end{tabular}


Table 4. (continued).

Facility Name: CFA-690, Radiological and Environmental Science Laboratory

Chapter IV. Low-Level Waste Requirements Facility Compliance Information

radioactive waste management basis, including shutdown of the facility.

G. Waste Acceptance. The following requirements are in addition to those in Chapter I of this Manual [DOE M 435.1-1 §I.2.F(6)].

(1) Technical and Administrative. Waste acceptance requirements for all low-level waste storage, treatment, or disposal facilities, operations, and activities shall specify, at a minimum, the following:

From DOE G 435.1-1 Chapter IV: Compliance with these waste acceptance requirements is demonstrated if they are documented, contain clear and precise criteria specifying the radionuclide limits in the form of contents or concentrations that can be accepted, the limitations and prohibitions on waste forms and packages that can be received, and the limits, prohibitions, or instructions concerning any other technical information so that the waste is compatible with the safety basis of the facility, and which will result in acceptable waste at subsequent steps in managing the low-level waste.

(a) Allowable activities and/or concentrations of specific radionuclides.

(b) Acceptable waste form and/or container requirements See (1) above. that ensure the chemical and physical stability of waste under conditions that might be encountered during transportation, storage, treatment, or disposal.

(c) Restrictions or prohibitions on waste, materials, or containers that may adversely affect waste handlers or compromise facility or waste container performance.

(d) The following are additional waste acceptance requirements that shall be specified in low-level waste disposal facility waste acceptance requirements:

1 Low-level waste must contribute to and not detract from achieving long-term stability of the facility, minimizing the need for long-term active maintenance, minimizing subsidence, and minimizing contact of water with waste. Void spaces within the waste and, if containers are used, between the waste and its container shall be reduced to the extent practical.

2 Liquid low-level waste or low-level waste containing free liquid must be converted into a form that contains as little freestanding liquid as is reasonably achievable, but in no case shall the liquid exceed 1 percent of the waste volume when the low-level waste is in a disposal container, or 0.5 percent of the waste volume after it is processed to a stable form.

NA; this facility does not accept LLW from other facilities.
See (1) above.

See (1) above.

See (1) above.

See (1) above.

See

DOE Manual 435.1-1 §I.2.F(6) applies to field element managers. 
Table 4. (continued).

\begin{tabular}{|c|c|}
\hline \multicolumn{2}{|c|}{ Facility Name: CFA-690, Radiological and Environmental Science Laboratory } \\
\hline Chapter IV. Low-Level Waste Requirements & Facility Compliance Information \\
\hline $\begin{array}{l}3 \text { Low-level waste must not be readily capable of } \\
\text { detonation or of explosive decomposition or reaction at } \\
\text { anticipated pressures and temperatures, or of explosive } \\
\text { reaction with water. Pyrophoric materials contained in } \\
\text { waste shall be treated, prepared, and packaged to be } \\
\text { nonflammable. }\end{array}$ & See (1) above. \\
\hline $\begin{array}{l}4 \text { Low-level waste must not contain, or be capable of } \\
\text { generating by radiolysis or biodegradation, quantities of } \\
\text { toxic gases, vapors, or fumes harmful to the public or } \\
\text { workers or disposal facility personnel, or harmful to the } \\
\text { long-term structural stability of the disposal site. }\end{array}$ & See (1) above. \\
\hline $\begin{array}{l}5 \text { Low-level waste in a gaseous form must be packaged } \\
\text { such that the pressure does not exceed } 1.5 \text { atmospheres } \\
\text { absolute at } 20 \mathrm{C} \text {. [ sic] }\end{array}$ & See (1) above. \\
\hline $\begin{array}{l}\text { (e) The basis, procedures, and levels of authority } \\
\text { required for granting exceptions to the waste acceptance } \\
\text { requirements, which shall be contained in each facility's } \\
\text { waste acceptance documentation. Each exception request } \\
\text { shall be documented, including its disposition as } \\
\text { approved or not approved. }\end{array}$ & See (1) above. \\
\hline $\begin{array}{l}\text { From DOE G } 435.1-1 \text { Chapter IV: Waste acceptance } \\
\text { requirements are acceptable if they are documented and } \\
\text { contain a clear description of the procedure and bases for } \\
\text { obtaining an exception or deviation to the acceptance } \\
\text { criteria for low-level waste to be received at the facility. }\end{array}$ & \\
\hline $\begin{array}{l}\text { (2) Evaluation and Acceptance. The receiving facility } \\
\text { shall evaluate waste for acceptance, including } \\
\text { confirmation that the technical and administrative } \\
\text { requirements have been met. A process for the } \\
\text { disposition of non-conforming wastes shall be } \\
\text { established. }\end{array}$ & See (1) above. \\
\hline $\begin{array}{l}\text { From DOE G 435.1-1 Chapter IV: Compliance with the } \\
\text { waste acceptance requirements for a low-level waste } \\
\text { management facility is demonstrated if they include a } \\
\text { process for evaluation and acceptance of incoming waste } \\
\text { to ensure the acceptance criteria of the facility receiving } \\
\text { the waste are met that includes one of or a combination } \\
\text { of: (1) testing, sampling, and analysis of representative } \\
\text { samples of waste upon receipt; (2) testing, sampling, and } \\
\text { analysis of split samples of waste taken at the generator } \\
\text { site; (3) evaluation of testing, sampling, and analysis of } \\
\text { data provided by the generator, or (4) audits, reviews, } \\
\text { surveillance, or observations of generator waste } \\
\text { certification programs and characterization activities. } \\
\text { Additionally, acceptable waste acceptance requirements } \\
\text { for a storage, treatment or disposal facility will have } \\
\text { documented procedures and actions to be taken if a } \\
\text { waste that does not conform to the waste acceptance }\end{array}$ & \\
\hline
\end{tabular}


Table 4. (continued).

\begin{tabular}{|c|c|}
\hline \multicolumn{2}{|c|}{ Facility Name: CFA-690, Radiological and Environmental Science Laboratory } \\
\hline Chapter IV. Low-Level Waste Requirements & Facility Compliance Information \\
\hline criteria is received at the facility. & \\
\hline $\begin{array}{l}\text { H. Waste Generation Planning. The following } \\
\text { requirements are in addition to those in Chapter I of this } \\
\text { Manual [DOE M 435.1-1 §I.2.F(7)]. }\end{array}$ & $\begin{array}{l}\text { DOE Manual 435.1-1 §I.2.F(7) applies to field element } \\
\text { managers. }\end{array}$ \\
\hline $\begin{array}{l}\text { (1) Life-Cycle Planning. Prior to waste generation, } \\
\text { planning shall be performed to address the entire life } \\
\text { cycle for all low-level waste streams. }\end{array}$ & $\begin{array}{l}\text { PDD- } 17000 \text { and LWP- } 17000 \text { provide direction to the } \\
\text { waste generators for waste generation planning to address } \\
\text { the entire life cycle. }\end{array}$ \\
\hline $\begin{array}{l}\text { From DOE G 435.1-1 Chapter IV: Compliance with this } \\
\text { planning requirement is demonstrated by the individual } \\
\text { sites establishing a process for evaluating the life-cycle } \\
\text { of low-level waste prior to its generation, including the } \\
\text { identification of low-level wastes with no path to } \\
\text { disposal and appropriate records justifying the newly } \\
\text { generated low-level waste stream(s), and site personnel } \\
\text { possessing planning information showing the location(s) } \\
\text { where low-level waste will be stored, treated, and/or } \\
\text { disposed along with a confirmation that the personnel } \\
\text { managing the facilities agree that the low-level waste } \\
\text { may be managed at those facilities. }\end{array}$ & \\
\hline $\begin{array}{l}\text { (2) Waste with No Identified Path to Disposal. Low-level } \\
\text { waste streams with no identified path to disposal shall be } \\
\text { generated only in accordance with approved conditions } \\
\text { which, at a minimum, shall address: }\end{array}$ & $\begin{array}{l}\text { This facility does not generate radioactive waste that does } \\
\text { not have an identified path to disposal. }\end{array}$ \\
\hline (a) Programmatic need to generate the waste; & See (2) above. \\
\hline $\begin{array}{l}\text { (b) Characteristics and issues preventing the disposal of } \\
\text { the waste; }\end{array}$ & See (2) above. \\
\hline $\begin{array}{l}\text { (c) Safe storage of the waste until disposal can be } \\
\text { achieved; and }\end{array}$ & See (2) above. \\
\hline $\begin{array}{l}\text { (d) Activities and plans for achieving final disposal of } \\
\text { the waste. }\end{array}$ & See (2) above. \\
\hline $\begin{array}{l}\text { I. Waste Characterization. Low-level waste shall be } \\
\text { characterized using direct or indirect methods, and the } \\
\text { characterization documented in sufficient detail to ensure }\end{array}$ & $\begin{array}{l}\text { MCP-17000 } \$ 4 \text { specifies the requirements for preparing } \\
\text { an IWTS profile that captures waste characterization } \\
\text { information. }\end{array}$ \\
\hline $\begin{array}{l}\text { Sate management and complance with the waste } \\
\text { acceptance requirements of the facility receiving the } \\
\text { waste. }\end{array}$ & $\begin{array}{l}\text { RESL-AP-10 states that the aim of the procedure is to } \\
\text { document waste management roles and responsibilities } \\
\text { associated with waste management at the RESL facility }\end{array}$ \\
\hline $\begin{array}{l}\text { From DOE G 435.1-1 Chapter IV: Compliance with this } \\
\text { requirement is demonstrated by a program for } \\
\text { documenting and the existence of records that document } \\
\text { the process for acquiring and verifying the validity of } \\
\text { low-level waste characterization data acquired through } \\
\text { the use of direct or indirect methods. }\end{array}$ & $\begin{array}{l}\text { "...consistent with the Idaho Site waste management } \\
\text { procedures." Section } 4.0 \text { addresses the need for laboratory } \\
\text { personnel to consult with Waste Generator Services } \\
\text { personnel prior to waste generation and to provide all } \\
\text { available information on the waste if already generated to } \\
\text { allow proper disposal by Waste Generator Services. }\end{array}$ \\
\hline $\begin{array}{l}\text { (1) Data Quality Objectives. The data quality objectives } \\
\text { process, or a comparable process, shall be used for } \\
\text { identifying characterization parameters and acceptable }\end{array}$ & $\begin{array}{l}\text { Radioactive waste management facilities characterize } \\
\text { waste in accordance with the requirements of the } \\
\text { receiving storage, treatment, or disposal facility. The }\end{array}$ \\
\hline
\end{tabular}


Table 4. (continued).

\section{Facility Name: CFA-690, Radiological and Environmental Science Laboratory}

Chapter IV. Low-Level Waste Requirements

uncertainty in characterization data.

From DOE G 435.1-1 Chapter IV: Compliance with this requirement is demonstrated by the documented use of a data quality objectives or a comparable process for determining the type, quantity, and quality of characterization data needed to safely manage low-level waste.

(2) Minimum Waste Characterization. Characterization data shall, at a minimum, include the following information relevant to the management of the waste:

From DOE G 435.1-1 Chapter IV: Compliance with this requirement is demonstrated by the existence of a program or procedure for determining and records that document characterization of low-level waste consistent with the minimum characterization data requirements.
Facility Compliance Information

documented use of a data quality objectives process, or comparable process, was not identified for this facility.

MCP- $17000 \$ 4$ specifies the requirements for preparing an IWTS profile that captures waste characterization information.

RESL-AP-10 states that the aim of the procedure is to document waste management roles and responsibilities associated with waste management at the RESL facility "...consistent with the Idaho Site waste management procedures." Section 4.0 addresses the need for laboratory personnel to consult with Waste Generator Services personnel prior to waste generation and to provide all available information on the waste if already generated to allow proper disposal by Waste Generator Services.

(a) Physical and chemical characteristics; See (2) above.

(b) Volume, including the waste and any stabilization or absorbent media;

(c) Weight of the container and contents;

(d) Identities, activities, and concentrations of major radionuclides;

(e) Characterization date;

(f) Generating source; and

(g) Any other information which may be needed to prepare and maintain the disposal facility performance assessment, or demonstrate compliance with applicable performance objectives.

J. Waste Certification. A waste certification program shall be developed, documented, and implemented to ensure that the waste acceptance requirements of facilities receiving low-level waste for storage, treatment, and disposal are met.

From DOE G 435.1-1 Chapter IV: Compliance with the development and documentation portion of the certification requirement is demonstrated by a waste certification plan that identifies the organizations involved, assigns responsibilities for implementing the program, and describes or references the quality assurance, training, procurement controls, records management, and procedures to be used by the program. Acceptable performance for implementing the program
See (2) above. See (2) above.

See (2) above. See (2) above.

See (2) above.

See (2) above.

MCP-17000 $\$ 4$ specifies the requirements for preparing an IWTS profile that captures waste certification information.

MCP-17500 provides the Waste Generator Services Waste Certification Program for LLW to be shipped to NNSS.

Container procurement is addressed in MCP-17000 §4.6.

Waste certification is performed and tracked using IWTS.

Documentation of the IWTS program is only available electronically.

PLN-522 requires waste technical specialists and waste disposition specialists to complete the appropriate 
Table 4. (continued).

\begin{tabular}{|c|c|}
\hline \multicolumn{2}{|c|}{ Facility Name: CFA-690, Radiological and Environmental Science Laboratory } \\
\hline Chapter IV. Low-Level Waste Requirements & Facility Compliance Information \\
\hline $\begin{array}{l}\text { is demonstrated when appropriate personnel are trained } \\
\text { and follow the procedures that govern their part of the } \\
\text { waste certification. Additionally, acceptable performance } \\
\text { is demonstrated if the waste certification plan and } \\
\text { procedures are current and controlled in accordance with } \\
\text { a document controls program, and records related to } \\
\text { certification (e.g., certification statements, training } \\
\text { records, procurement records, characterization records, } \\
\text { container records) are generated and managed in } \\
\text { accordance with the established site program. }\end{array}$ & $\begin{array}{l}\text { training/qualification before being granted approval } \\
\text { authority for profiles within the IWTS Program. The } \\
\text { waste certification official, alternate waste certification } \\
\text { official, and NNSS packaging certifiers must complete the } \\
\text { appropriate training/qualifications to disposition waste to } \\
\text { NNSS. }\end{array}$ \\
\hline $\begin{array}{l}\text { (1) Certification Program. The waste certification } \\
\text { program shall designate the officials who have the } \\
\text { authority to certify and release waste for shipment; and } \\
\text { specify what documentation is required for waste } \\
\text { generation, characterization, shipment, and certification. } \\
\text { The program shall provide requirements for auditability, } \\
\text { retrievability, and storage of required documentation and } \\
\text { specify the records retention period. }\end{array}$ & See J. above. \\
\hline $\begin{array}{l}\text { From DOE G } 435.1-1 \text { Chapter IV: Compliance with this } \\
\text { requirement is demonstrated by a program or procedure } \\
\text { for record keeping and records showing that low-level } \\
\text { waste is certified as having met the waste acceptance } \\
\text { criteria of the facility to which it was transferred and that } \\
\text { the certification statement is supported by additional } \\
\text { records regarding the waste source, characterization, and } \\
\text { container. }\end{array}$ & \\
\hline $\begin{array}{l}\text { (2) Certification before Transfer. Low-level waste shall } \\
\text { be certified as meeting waste acceptance requirements } \\
\text { before it is transferred to the facility receiving the waste. }\end{array}$ & See J. above. \\
\hline $\begin{array}{l}\text { From DOE G } 435.1-1 \text { Chapter IV: Compliance with this } \\
\text { requirement is demonstrated by the presence of a } \\
\text { certification program which includes procedures } \\
\text { requiring a signed certification statement prior to the } \\
\text { release of waste for transfer, and by dated records } \\
\text { showing that waste was certified before being } \\
\text { transferred. }\end{array}$ & \\
\hline $\begin{array}{l}\text { (3) Maintaining Certification. Low-level waste that has } \\
\text { been certified as meeting the waste acceptance } \\
\text { requirements for transfer to a storage, treatment, or } \\
\text { disposal facility shall be managed in a manner that } \\
\text { maintains its certification status. }\end{array}$ & See J. above. \\
\hline $\begin{array}{l}\text { From DOE G } 435.1-1 \text { Chapter IV: Compliance with this } \\
\text { requirement is demonstrated by a program or procedure } \\
\text { reflecting this requirement is present and site personnel } \\
\text { are able to show that the storage of low-level waste } \\
\text { containers is in a facility or manner where the containers } \\
\text { would not be damaged by normal weather events, and } \\
\text { cannot be accessed by unauthorized personnel. Further, }\end{array}$ & \\
\hline
\end{tabular}


Table 4. (continued).

\begin{tabular}{|c|c|}
\hline \multicolumn{2}{|c|}{ Facility Name: CFA-690, Radiological and Environmental Science Laboratory } \\
\hline Chapter IV. Low-Level Waste Requirements & Facility Compliance Information \\
\hline $\begin{array}{l}\text { each container can be traced to its certification and the } \\
\text { information supporting that certification. }\end{array}$ & \\
\hline $\begin{array}{l}\text { K. Waste Transfer. A documented process shall be } \\
\text { established and implemented for transferring } \\
\text { responsibility for management of low-level waste and for }\end{array}$ & $\begin{array}{l}\text { MCP-17000 specifies the requirements for preparing an } \\
\text { IWTS profile that captures waste certification data, } \\
\text { transfer information, and associated authorizations. }\end{array}$ \\
\hline $\begin{array}{l}\text { requirements are in addition to those in Chapter I of this } \\
\text { Manual. }\end{array}$ & $\begin{array}{l}\text { MCP- } 17500 \text { provides the Waste Generator Services } \\
\text { Waste Certification Program for LLW to be shipped to } \\
\text { NNSS. }\end{array}$ \\
\hline $\begin{array}{l}\text { From DOE G } 435.1-1 \text { Chapter IV: Compliance with this } \\
\text { requirement is demonstrated if facilities have procedures } \\
\text { for the receipt of waste and the transfer of waste, as } \\
\text { appropriate, which address the acquisition of waste and } \\
\text { container data and the transfer of ownership, } \\
\text { respectively. Further evidence of acceptable performance } \\
\text { is facility records showing that data on the waste } \\
\text { containers is available and accurate, and that documented } \\
\text { transfer of responsibility occurs. }\end{array}$ & \\
\hline $\begin{array}{l}\text { (1) Authorization. Low-level waste shall not be } \\
\text { transferred to a storage, treatment, or disposal facility } \\
\text { until personnel responsible for the facility receiving the } \\
\text { waste authorize the transfer. }\end{array}$ & See K. above. \\
\hline $\begin{array}{l}\text { From DOE G 435.1-1 Chapter IV: Compliance with this } \\
\text { requirement is demonstrated by sites having procedures } \\
\text { that require a confirmation of authorization before } \\
\text { releasing waste for transfer, and records showing that } \\
\text { transfers are made in accordance with written } \\
\text { authorizations. }\end{array}$ & \\
\hline $\begin{array}{l}\text { (2) Data. Waste characterization data, container } \\
\text { information, and generation, storage, treatment, and } \\
\text { transportation information for low-level waste shall be } \\
\text { transferred with or be traceable to the waste. }\end{array}$ & See K. above. \\
\hline $\begin{array}{l}\text { From DOE G 435.1-1 Chapter IV: Compliance with this } \\
\text { requirement is demonstrated if there are procedures } \\
\text { requiring that characterization and container data be } \\
\text { provided and maintained for each low-level waste } \\
\text { transfer and documented records of transfers show that } \\
\text { the information is being provided. }\end{array}$ & \\
\hline $\begin{array}{l}\text { L. Packaging and Transportation. The following } \\
\text { requirements are in addition to those in Chapter I of this } \\
\text { Manual [DOE M 435.1-1 §I.1.E(11)]. }\end{array}$ & $\begin{array}{l}\text { DOE Manual 435.1-1 §I.1.E(11) applies to field element } \\
\text { managers. }\end{array}$ \\
\hline (1) Packaging. If containers are used: & MCP-17000 §4. addresses packaging requirements. \\
\hline $\begin{array}{l}\text { From DOE G } 435.1-1 \text { Chapter IV: Compliance with the } \\
\text { packaging requirement is demonstrated by: (1) } \\
\text { procedures which document proper packaging protocols; } \\
\text { and (2) no trends of routine repackaging of low-level } \\
\text { waste that is packaged after issuance of DOE O } 435.1 \text {. } \\
\text { Successful performance of this requirement is also }\end{array}$ & \\
\hline
\end{tabular}


Table 4. (continued).

Facility Name: CFA-690, Radiological and Environmental Science Laboratory

\section{Chapter IV. Low-Level Waste Requirements demonstrated by a record of containers for which failure has not routinely occurred under management conditions. It is recognized that there may be failed containers for waste previously placed in storage. For those containers, the goal is to only have to repackage the waste one time after it is retrieved and characterized. Further, acceptable performance is demonstrated by containers of waste having marking and labeling that allows correlation with waste characterization data and container information.}

(a) Low-level waste shall be packaged in a manner that provides containment and protection for the duration of the anticipated storage period and until disposal is achieved or until the waste has been removed from the container.

(b) When waste is packaged, vents or other measures shall be provided if the potential exists for pressurizing or generating flammable or explosive concentrations of gases within the waste container.

(c) Containers of low-level waste shall be marked such that their contents can be identified.

(2) Transportation. To the extent practical, the volume of waste and number of low-level waste shipments shall be minimized.

From DOE G 435.1-1 Chapter IV: Compliance with this requirement can be demonstrated by a combination of site procedures directing the efficient use of waste container capacity and documentation showing that lowlevel waste shipments are systematically planned and optimized to the extent practical.

M. Site Evaluation and Facility Design. The following requirements are in addition to those in Chapter I of this Manual.

(1) Site Evaluation. Proposed locations for low-level waste facilities shall be evaluated to identify relevant features that should be avoided or must be considered in facility design and analyses.

(a) Each site proposed for a new low-level waste facility See M. above. or expansion of an existing low-level waste facility shall be evaluated considering environmental characteristics, geotechnical characteristics, and human activities, including for a low-level waste disposal facility, the capability of the site to demonstrate, at a minimum, whether it is:

1 Located to accommodate the projected volume of waste to be received;

\section{Facility Compliance Information}

See (1) above.

See (1) above.

See (1) above.

NA; waste is not shipped to an offsite facility for final disposition from this facility.

NA; this requirement addresses new radioactive waste management facilities.

See M. above.

See M. above. 
Table 4. (continued).

\begin{tabular}{|c|c|}
\hline \multicolumn{2}{|c|}{ Facility Name: CFA-690, Radiological and Environmental Science Laboratory } \\
\hline Chapter IV. Low-Level Waste Requirements & Facility Compliance Information \\
\hline $\begin{array}{l}2 \text { Located in a flood plain, a tectonically active area, or } \\
\text { in the zone of water table fluctuation; and }\end{array}$ & See M. above. \\
\hline $\begin{array}{l}3 \text { Located where radionuclide migration pathways are } \\
\text { predictable and erosion and surface runoff can be } \\
\text { controlled. }\end{array}$ & See M. above. \\
\hline $\begin{array}{l}\text { (b) Proposed sites with environmental characteristics, } \\
\text { geotechnical characteristics, and human activities for } \\
\text { which adequate protection cannot be provided through } \\
\text { facility design shall be deemed unsuitable for the } \\
\text { location of the facility. }\end{array}$ & See M. above. \\
\hline $\begin{array}{l}\text { (c) Low-level waste disposal facilities shall be sited to } \\
\text { achieve long-term stability and to minimize, to the extent } \\
\text { practical, the need for active maintenance following final } \\
\text { closure. }\end{array}$ & See M. above. \\
\hline $\begin{array}{l}\text { (2) Low-Level Waste Treatment and Storage Facility } \\
\text { Design. The following facility requirements and general } \\
\text { design criteria, at a minimum, apply: }\end{array}$ & See M. above. \\
\hline $\begin{array}{l}\text { (a) Confinement. Low-level waste systems and } \\
\text { components shall be designed to maintain waste } \\
\text { confinement. }\end{array}$ & See M. above. \\
\hline (b) Ventilation. & See M. above. \\
\hline $\begin{array}{l}1 \text { Design of low-level waste treatment and storage } \\
\text { facilities shall include ventilation, if applicable, through } \\
\text { an appropriate filtration system to maintain the release of } \\
\text { radioactive material in airborne effluents within the } \\
\text { requirements and guidelines specified in applicable } \\
\text { requirements. }\end{array}$ & See M. above. \\
\hline $\begin{array}{l}2 \text { When conditions exist for generating gases in } \\
\text { flammable or explosive concentrations, ventilation } \\
\text { systems or other measures shall be provided to keep the } \\
\text { gases in a non-flammable and nonexplosive condition. } \\
\text { Where concentrations of explosive or flammable gases } \\
\text { are expected to approach the lower flammability limit, } \\
\text { measures shall be taken to prevent deflagration or } \\
\text { detonation. }\end{array}$ & See M. above. \\
\hline $\begin{array}{l}\text { (c) Consideration of Decontamination and } \\
\text { Decommissioning. Areas in new and modifications to } \\
\text { existing low-level waste management facilities that are } \\
\text { subject to contamination with radioactive or other } \\
\text { hazardous materials shall be designed to facilitate } \\
\text { decontamination. For such facilities a proposed } \\
\text { decommissioning method or a conversion method } \\
\text { leading to reuse shall be described. }\end{array}$ & See M. above. \\
\hline $\begin{array}{l}\text { (d) Instrumentation and Control Systems. Engineering } \\
\text { controls shall be incorporated in the design and }\end{array}$ & See M. above. \\
\hline
\end{tabular}


Table 4. (continued).

Facility Name: CFA-690, Radiological and Environmental Science Laboratory

Chapter IV. Low-Level Waste Requirements Facility Compliance Information

engineering of low-level waste treatment and storage facilities to provide volume inventory data and to prevent spills, leaks, and overflows from tanks or confinement systems.

(e) Monitoring. Monitoring and/or leak detection capabilities shall be incorporated in the design and engineering of low-level waste treatment and storage facilities to provide rapid identification of failed confinement and/or other abnormal conditions.

(3) Low-Level Waste Disposal Facility Design. The following facility requirements and general design criteria, at a minimum, apply:

(a) Confinement. Low-level waste systems and components shall be designed to maintain waste confinement.

(b) Ventilation. See M. above.

1 Design of low-level waste disposal facilities shall

See M. above. include ventilation, if applicable, through an appropriate filtration system to maintain the release of radioactive material in airborne effluents within the requirements and guidelines specified in applicable requirements.

2 When conditions exist for generating gases in flammable or explosive concentrations, ventilation systems or other measures shall be provided to keep the gases in a nonflammable and non-explosive condition. Where concentrations of explosive or flammable gases are expected to approach the lower flammability limit, measures shall be taken to prevent deflagration or detonation.

(c) Stability. Low-level waste disposal facilities shall be designed to achieve long-term stability and to minimize to the extent practical, the need for active maintenance following final closure.

(d) Control of Water. Low-level waste disposal facilities shall be designed to minimize to the extent practical, the contact of waste with water during and after disposal.

N. Storage and Staging. The following requirements are in addition to those in Chapter I of this Manual [DOE M 435.1-1 §I.2.F(13)].

(1) Storage Prohibitions. Low-level waste in storage shall not be readily capable of detonation, explosive decomposition, reaction at anticipated pressures and temperatures, or explosive reaction with water. Prior to storage, pyrophoric materials shall be treated, prepared, and packaged to be nonflammable.

See M. above.

See M. above.

See M. above.

See M. above.

See M. above.

See M. above.

DOE Manual 435.1-1 §I.2.F(13) applies to field element managers.

$\mathrm{N}$; this facility does not store LLW. 
Table 4. (continued).

\begin{tabular}{|c|c|}
\hline \multicolumn{2}{|c|}{ Facility Name: CFA-690, Radiological and Environmental Science Laboratory } \\
\hline Chapter IV. Low-Level Waste Requirements & Facility Compliance Information \\
\hline $\begin{array}{l}\text { From DOE G 435.1-1 Chapter IV: Compliance with this } \\
\text { requirement is demonstrated by having waste acceptance } \\
\text { requirements which prohibit low-level waste that is } \\
\text { ignitable or explosive from being accepted for storage } \\
\text { unless it has been treated, and procedures for properly } \\
\text { preparing such materials for safe storage. }\end{array}$ & \\
\hline $\begin{array}{l}\text { (2) Storage Limit. Low-level waste that has an identified } \\
\text { path to disposal shall not be stored longer than one year } \\
\text { prior to disposal, except for storage for decay, or as } \\
\text { otherwise authorized by the Field Element Manager. }\end{array}$ & $\begin{array}{l}\text { NA; this facility does not store LLW. See N. (7) below } \\
\text { for staging requirements. }\end{array}$ \\
\hline $\begin{array}{l}\text { From DOE G } 435.1-1 \text { Chapter IV: Storage longer than } \\
\text { one year can be justified if the conditions for such } \\
\text { storage are approved by the Field Element Manager as } \\
\text { part of the radioactive waste management basis for the } \\
\text { facility. }\end{array}$ & \\
\hline $\begin{array}{l}\text { Storage for radioactive decay for a period greater than } 1 \\
\text { year for waste that has an identified path to disposal is } \\
\text { allowed. Adequate justification and the supporting } \\
\text { information for storage for decay is to be documented in } \\
\text { the radioactive waste management basis for the facility } \\
\text { in which the storage will take place. }\end{array}$ & \\
\hline $\begin{array}{l}\text { Mixed waste. Under the Federal Facility Compliance Act } \\
\text { of } 1992 \text {, DOE sites were required to develop Site } \\
\text { Treatment Plans to bring stored mixed low-level waste } \\
\text { into compliance with these requirements. The Site } \\
\text { Treatment Plan needs to be consulted and any mixed } \\
\text { low-level waste stored for the purpose of accumulation } \\
\text { to facilitate treatment must meet Resource Conservation } \\
\text { and Recovery Act storage requirements. There could be } \\
\text { several ways within different scenarios that this } \\
\text { requirement can be met, as illustrated by the examples } \\
\text { below, however, there are basically four ways to show } \\
\text { compliance with the requirement and include appropriate } \\
\text { provisions in the radioactive waste management basis for } \\
\text { the facility in which it is stored. }\end{array}$ & \\
\hline $\begin{array}{l}\text { Legacy waste. As discussed above, the intention of the } \\
\text { requirement is not to force malicious compliance or } \\
\text { heroic actions which would result in increased risk or } \\
\text { safety concerns. Rather, the intention is that waste in } \\
\text { storage longer than one year receives additional attention } \\
\text { to ensure that the public, the workers, and the } \\
\text { environment are protected from the hazards of the waste, } \\
\text { and that progress is being made to dispose of the waste. } \\
\text { There could be several ways within different scenarios } \\
\text { that this requirement can be met, as illustrated by the } \\
\text { examples below, however, there are basically four ways } \\
\text { to show compliance with the requirement: }\end{array}$ & \\
\hline 1) the radioactive waste management basis allows for & \\
\hline
\end{tabular}


Table 4. (continued).

\begin{tabular}{|c|c|}
\hline \multicolumn{2}{|c|}{ Facility Name: CFA-690, Radiological and Environmental Science Laboratory } \\
\hline Chapter IV. Low-Level Waste Requirements & Facility Compliance Information \\
\hline storage for no more than one year. & \\
\hline $\begin{array}{l}\text { 2) the radioactive waste management basis allows for } \\
\text { storage for no more than one year, or for storage for } \\
\text { decay only for periods greater than a year, which are } \\
\text { specified on a radionuclide basis. }\end{array}$ & \\
\hline $\begin{array}{l}\text { 3) the radioactive waste management basis allows for } \\
\text { storage for more than one year, up to a specified period } \\
\text { of time based on a documented technical evaluation that } \\
\text { the waste can be stored in a manner that does not cause } \\
\text { changes to the waste or waste packages that is } \\
\text { detrimental to the safe storage of the waste, the final } \\
\text { disposal of the waste or to meeting the disposal } \\
\text { performance objectives. }\end{array}$ & \\
\hline $\begin{array}{l}\text { 4) the radioactive waste management basis allows for } \\
\text { storage for decay (with specifics) and for storage for } \\
\text { more than one year for other low-level waste, up to a } \\
\text { specified period of time based on a documented technical } \\
\text { evaluation that the waste can be stored in a manner that } \\
\text { does not cause changes to the waste or waste packages } \\
\text { that is detrimental to the safe storage of the waste, the } \\
\text { final disposal of the waste or to meeting the disposal } \\
\text { performance objectives. }\end{array}$ & \\
\hline $\begin{array}{l}\text { Compliance with this requirement is demonstrated by the } \\
\text { existence of a radioactive waste management basis for } \\
\text { the storage facility approved by the Field Element } \\
\text { Manager that includes the time frames that waste are } \\
\text { allowed to be stored, the necessary justifications for } \\
\text { storage for decay, and the necessary technical } \\
\text { evaluations if storage is to extend significantly beyond } \\
\text { the one-year time frame. }\end{array}$ & \\
\hline $\begin{array}{l}\text { (3) Storage Integrity. Low-level waste shall be stored in } \\
\text { a location and manner that protects the integrity of waste } \\
\text { for the expected time of storage and minimizes worker } \\
\text { exposure. }\end{array}$ & $\begin{array}{l}\text { NA; this facility does not store LLW. See N. (7) below } \\
\text { for staging requirements. }\end{array}$ \\
\hline $\begin{array}{l}\text { From DOE G } 435.1-1 \text { Chapter IV: However, in making a } \\
\text { decision to use a facility for storage and in developing a } \\
\text { radioactive waste management basis for the activity, } \\
\text { particular attention to protection of workers is needed. }\end{array}$ & \\
\hline $\begin{array}{l}\text { Compliance with this requirement is demonstrated if } \\
\text { sites have storage capabilities for low-level waste that } \\
\text { provide protection to waste containers so that their } \\
\text { integrity will not be damaged through physical or } \\
\text { chemical (corrosion) processes and that keep personnel } \\
\text { from spending extended periods of time in the areas } \\
\text { where low-level waste is stored. }\end{array}$ & \\
\hline (4) Waste Characterization for Storage. & $\begin{array}{l}\text { NA; this facility does not store LLW. See N. (7) below } \\
\text { for staging requirements. }\end{array}$ \\
\hline
\end{tabular}


Table 4. (continued).

\begin{tabular}{|c|c|}
\hline \multicolumn{2}{|c|}{ Facility Name: CFA-690, Radiological and Environmental Science Laboratory } \\
\hline Chapter IV. Low-Level Waste Requirements & Facility Compliance Information \\
\hline $\begin{array}{l}\text { (a) Low-level waste that does not have an identified path } \\
\text { to disposal shall be characterized as necessary to meet } \\
\text { the data quality objectives and minimum characterization } \\
\text { requirements of this Chapter, to ensure safe storage, and } \\
\text { to facilitate disposal. }\end{array}$ & $\begin{array}{l}\text { NA; this facility does not store LLW. See N. (7) below } \\
\text { for staging requirements. }\end{array}$ \\
\hline $\begin{array}{l}\text { (b) Characterization information for all low-level waste } \\
\text { in storage shall be maintained as a record in accordance } \\
\text { with the requirements for Records Management in } \\
\text { Chapter I of this Manual. }\end{array}$ & $\begin{array}{l}\text { NA; this facility does not store LLW. See N. (7) below } \\
\text { for staging requirements. }\end{array}$ \\
\hline $\begin{array}{l}\text { From DOE G 435.1-1 Chapter IV: Compliance with this } \\
\text { requirement is demonstrated by documented procedures } \\
\text { for managing waste characterization and container } \\
\text { information on low-level waste as a Federal record. The } \\
\text { records are managed per the applicable policies and } \\
\text { procedures for records management referenced in DOE } \\
\text { O } 200.1 \text { and established at the applicable Field Element. }\end{array}$ & \\
\hline $\begin{array}{l}\text { (5) Container Inspection. A process shall be developed } \\
\text { and implemented for inspecting and maintaining } \\
\text { containers of low-level waste to ensure container } \\
\text { integrity is not compromised. }\end{array}$ & $\begin{array}{l}\text { LI- } 435 \text { requires quarterly inspections of radioactive waste } \\
\text { containers if waste is stored outdoors or has been in } \\
\text { storage for greater than } 1 \text { year. }\end{array}$ \\
\hline $\begin{array}{l}\text { From DOE G } 435.1-1 \text { Chapter IV: Compliance with this } \\
\text { requirement is demonstrated by: (1) a documented } \\
\text { process for waste container inspection and maintenance; } \\
\text { and (2) documentation for all waste container inspections } \\
\text { and maintenance actions performed. }\end{array}$ & \\
\hline $\begin{array}{l}\text { (6) Storage Management. Low-level waste storage shall } \\
\text { be managed to identify and segregate low-level waste } \\
\text { from mixed low-level waste. }\end{array}$ & $\begin{array}{l}\text { NA; this facility does not store LLW. See N. (7) below } \\
\text { for staging requirements. }\end{array}$ \\
\hline $\begin{array}{l}\text { (7) Staging. Staging of low-level waste shall be for the } \\
\text { purpose of the accumulation of such quantities of waste } \\
\text { as necessary to facilitate transportation, treatment, and } \\
\text { disposal. Staging longer than } 90 \text { days shall meet the } \\
\text { requirements for storage above and in Chapter I of this } \\
\text { Manual. }\end{array}$ & $\begin{array}{l}\text { Routine LLW, such as personal protective equipment, is } \\
\text { accumulated at this facility for disposal. MCP-17000, } \\
\text { Appendix F, "Container Start Date and Storage } \\
\text { Prohibitions," restricts staging LLW to a 90-day } \\
\text { maximum at any generator or treatment facility prior to } \\
\text { acceptance by a storage facility. }\end{array}$ \\
\hline $\begin{array}{l}\text { From DOE G } 435.1-1 \text { Chapter IV: The staging of low- } \\
\text { level waste needs to be addressed in the radioactive } \\
\text { waste management basis for the facility that is } \\
\text { performing the staging. Generators, treatment facilities, } \\
\text { and disposal facilities that stage waste must ensure that } \\
\text { the action of staging is included and authorized as part of } \\
\text { their radioactive waste management basis for the } \\
\text { affected facilities, operations, or activities. }\end{array}$ & $\begin{array}{l}\text { As stated in DOE Guide } 435.1-1 \S \text { IV.N.(7), staging waste } \\
\text { in accordance with this requirement allows waste to be } \\
\text { accumulated without being considered storage and being } \\
\text { bound by the associated storage requirements. }\end{array}$ \\
\hline $\begin{array}{l}\text { Staging longer than } 90 \text { days must be justified, the } \\
\text { conditions for such storage met, and these practices } \\
\text { approved by the Field Element Manager as part of the } \\
\text { radioactive waste management basis for the facility. }\end{array}$ & \\
\hline
\end{tabular}


Table 4. (continued).

\begin{tabular}{|c|c|}
\hline \multicolumn{2}{|c|}{ Facility Name: CFA-690, Radiological and Environmental Science Laboratory } \\
\hline Chapter IV. Low-Level Waste Requirements & Facility Compliance Information \\
\hline $\begin{array}{l}\text { Compliance with this requirement is demonstrated by a } \\
\text { staging program that limits the temporary storage of } \\
\text { waste to only circumstances allowed in the requirement, } \\
\text { including justifications for any staging that exceeds the } \\
90 \text {-day period, which is documented in the radioactive } \\
\text { waste management basis for the facility. }\end{array}$ & \\
\hline $\begin{array}{l}\text { O. Treatment. Low-level waste treatment to provide } \\
\text { more stable waste forms and to improve the long-term } \\
\text { performance of a low-level waste disposal facility shall } \\
\text { be implemented as necessary to meet the performance } \\
\text { objectives of the disposal facility. }\end{array}$ & NA; this facility does not treat LLW. \\
\hline $\begin{array}{l}\text { From DOE G } 435.1-1 \text { Chapter IV: Compliance with this } \\
\text { requirement is demonstrated when a treatment facility or } \\
\text { process ensures that treated waste will meet the } \\
\text { minimum waste form requirements of DOE M } 435.1 \text { and } \\
\text { meet additional disposal facility-specific waste } \\
\text { acceptance requirements for additional stability or long- } \\
\text { term performance of facilities that will receive the } \\
\text { treated waste. }\end{array}$ & \\
\hline $\begin{array}{l}\text { P. Disposal. Low-level waste disposal facilities shall } \\
\text { meet the following requirements. }\end{array}$ & NA; this facility does not dispose of LLW. \\
\hline $\begin{array}{l}\text { (1) Performance Objectives. Low-level waste disposal } \\
\text { facilities shall be sited, designed, operated, maintained, } \\
\text { and closed so that a reasonable expectation exists that the } \\
\text { following performance objectives will be met for waste } \\
\text { disposed of after September } 26,1988 \text { : }\end{array}$ & See P. above. \\
\hline $\begin{array}{l}\text { (a) Dose to representative members of the public shall } \\
\text { not exceed } 25 \text { mrem }(0.25 \mathrm{mSv}) \text { in a year total effective } \\
\text { dose equivalent from all exposure pathways, excluding } \\
\text { the dose from radon and its progeny in air. }\end{array}$ & See P. above. \\
\hline $\begin{array}{l}\text { (b) Dose to representative members of the public via the } \\
\text { air pathway shall not exceed } 10 \mathrm{mrem}(0.10 \mathrm{mSv}) \text { in a } \\
\text { year total effective dose equivalent, excluding the dose } \\
\text { from radon and its progeny. }\end{array}$ & See P. above. \\
\hline $\begin{array}{l}\text { (c) Release of radon shall be less than an average flux of } \\
20 \mathrm{pCi} / \mathrm{m}^{2} / \mathrm{s}\left(0.74 \mathrm{~Bq} / \mathrm{m}^{2} / \mathrm{s}\right) \text { at the surface of the disposal } \\
\text { facility. Alternatively, a limit of } 0.5 \mathrm{pCi} / 1(0.0185 \mathrm{~Bq} / \mathrm{l}) \\
\text { of air may be applied at the boundary of the facility. }\end{array}$ & See P. above. \\
\hline $\begin{array}{l}\text { (2) Performance Assessment. A site-specific radiological } \\
\text { performance assessment shall be prepared and } \\
\text { maintained for DOE low-level waste disposed of after } \\
\text { September } 26,1988 \text {. The performance assessment shall } \\
\text { include calculations for a } 1,000 \text { year period after closure } \\
\text { of potential doses to representative future members of } \\
\text { the public and potential releases from the facility to } \\
\text { provide a reasonable expectation that the performance } \\
\text { objectives identified in this Chapter are not exceeded as }\end{array}$ & See P. above. \\
\hline
\end{tabular}


Table 4. (continued).

Facility Name: CFA-690, Radiological and Environmental Science Laboratory

\begin{tabular}{|c|c|}
\hline Chapter IV. Low-Level Waste Requirements & Facility Compliance Information \\
\hline a result of operation and closure of the facility. & \\
\hline $\begin{array}{l}\text { (a) Analyses performed to demonstrate compliance with } \\
\text { the performance objectives in this Chapter, and to } \\
\text { establish limits on concentrations of radionuclides for } \\
\text { disposal based on the performance measures for } \\
\text { inadvertent intruders in this Chapter shall be based on } \\
\text { reasonable activities in the critical group of exposed } \\
\text { individuals. Unless otherwise specified, the assumption } \\
\text { of average living habits and exposure conditions in } \\
\text { representative critical groups of individuals projected to } \\
\text { receive the highest doses is appropriate. The likelihood } \\
\text { of inadvertent intruder scenarios may be considered in } \\
\text { interpreting the results of the analyses and establishing } \\
\text { radionuclide concentrations, if adequate justification is } \\
\text { provided. }\end{array}$ & See P. above. \\
\hline $\begin{array}{l}\text { (b) The point of compliance shall correspond to the point } \\
\text { of highest projected dose or concentration beyond a } 100 \\
\text { meter buffer zone surrounding the disposed waste. A } \\
\text { larger or smaller buffer zone may be used if adequate } \\
\text { justification is provided. }\end{array}$ & See P. above. \\
\hline $\begin{array}{l}\text { (c) Performance assessments shall address reasonably } \\
\text { foreseeable natural processes that might disrupt barriers } \\
\text { against release and transport of radioactive materials. }\end{array}$ & See P. above. \\
\hline $\begin{array}{l}\text { (d) Performance assessments shall use DOE-approved } \\
\text { dose coefficients (dose conversion factors) for internal } \\
\text { and external exposure of reference adults. }\end{array}$ & See P. above. \\
\hline $\begin{array}{l}\text { (e) The performance assessment shall include a } \\
\text { sensitivity/uncertainty analysis. }\end{array}$ & See P. above. \\
\hline $\begin{array}{l}\text { (f) Performance assessments shall include a } \\
\text { demonstration that projected releases of radionuclides to } \\
\text { the environment shall be maintained as low as } \\
\text { reasonably achievable (ALARA). }\end{array}$ & See P. above. \\
\hline $\begin{array}{l}\text { (g) For purposes of establishing limits on radionuclides } \\
\text { that may be disposed of near-surface, the performance } \\
\text { assessment shall include an assessment of impacts to } \\
\text { water resources. }\end{array}$ & See P. above. \\
\hline $\begin{array}{l}\text { (h) For purposes of establishing limits on the } \\
\text { concentration of radionuclides that may be disposed of } \\
\text { near-surface, the performance assessment shall include } \\
\text { an assessment of impacts calculated for a hypothetical } \\
\text { person assumed to inadvertently intrude for a temporary } \\
\text { period into the low-level waste disposal facility. For } \\
\text { intruder analyses, institutional controls shall be assumed } \\
\text { to be effective in deterring intrusion for at least } 100 \text { years } \\
\text { following closure. The intruder analyses shall use } \\
\text { performance measures for chronic and acute exposure } \\
\text { scenarios, respectively, of } 100 \text { mrem }(1 \mathrm{mSv}) \text { in a year }\end{array}$ & See P. above. \\
\hline
\end{tabular}


Table 4. (continued).

Facility Name: CFA-690, Radiological and Environmental Science Laboratory

Chapter IV. Low-Level Waste Requirements Facility Compliance Information

and $500 \mathrm{mrem}(5 \mathrm{mSv})$ total effective dose equivalent excluding radon in air.

(3) Composite Analysis. For disposal facilities which

See P. above. received waste after September 26, 1988, a site-specific radiological composite analysis shall be prepared and maintained that accounts for all sources of radioactive material that may be left at the DOE site and may interact with the low- level waste disposal facility, contributing to the dose projected to a hypothetical member of the public from the existing or future disposal facilities. Performance measures shall be consistent with DOE requirements for protection of the public and environment and evaluated for a 1,000 year period following disposal facility closure. The composite analysis results shall be used for planning, radiation protection activities, and future use commitments to minimize the likelihood that current low- level waste disposal activities will result in the need for future corrective or remedial actions to adequately protect the public and the environment.

(4) Performance Assessment and Composite Analysis Maintenance. The performance assessment and composite analysis shall be maintained to evaluate changes that could affect the performance, design, and operating bases for the facility. Performance assessment and composite analysis maintenance shall include the conduct of research, field studies, and monitoring needed to address uncertainties or gaps in existing data. The performance assessment shall be updated to support the final facility closure. Additional iterations of the performance assessment and composite analysis shall be conducted as necessary during the post-closure period.

(a) Performance assessments and composite analyses shall be reviewed and revised when changes in waste forms or containers, radionuclide inventories, facility design and operations, closure concepts, or the improved understanding of the performance of the waste disposal facility in combination with the features of the site on which it is located alter the conclusions or the conceptual model(s) of the existing performance assessment or composite analysis.

(b) A determination of the continued adequacy of the See P. above. performance assessment and composite analysis shall be made on an annual basis, and shall consider the results of data collection and analysis from research, field studies, and monitoring.

(c) Annual summaries of low-level waste disposal operations shall be prepared with respect to the conclusions and recommendations of the performance

See P. above.

See P. above.

See P. above. (5ection 西

See P. above.


Table 4. (continued).

Facility Name: CFA-690, Radiological and Environmental Science Laboratory

\begin{tabular}{|c|c|}
\hline \multicolumn{2}{|c|}{ Facility Name: CFA-690, Radiological and Environmental Science Laboratory } \\
\hline Chapter IV. Low-Level Waste Requirements & Facility Compliance Information \\
\hline $\begin{array}{l}\text { assessment and composite analysis and a determination } \\
\text { of the need to revise the performance assessment or } \\
\text { composite analysis. }\end{array}$ & \\
\hline $\begin{array}{l}\text { (5) Disposal Authorization. A disposal authorization } \\
\text { statement shall be obtained prior to construction of a new } \\
\text { low-level waste disposal facility. Field Elements with } \\
\text { existing low-level waste disposal facilities shall obtain a } \\
\text { disposal authorization statement in accordance with the } \\
\text { schedule in the Complex-Wide Low-Level Waste } \\
\text { Management Program Plan. The disposal authorization } \\
\text { statement shall be issued based on a review of the } \\
\text { facility's performance assessment, composite analysis, } \\
\text { performance assessment and composite analysis } \\
\text { maintenance, preliminary closure plan, and preliminary } \\
\text { monitoring plan. The disposal authorization statement } \\
\text { shall specify the limits and conditions on construction, } \\
\text { design, operations, and closure of the low-level waste } \\
\text { facility based on these reviews. A disposal authorization } \\
\text { statement is a part of the radioactive waste management } \\
\text { basis for a disposal facility. Failure to obtain a disposal } \\
\text { authorization statement by the implementation date of } \\
\text { this Order shall result in shutdown of the disposal } \\
\text { facility. }\end{array}$ & \begin{tabular}{|l} 
See P. above. \\
S \\
\end{tabular} \\
\hline $\begin{array}{l}\text { (6) Disposal Facility Operations. The disposal facility } \\
\text { design and operation must be consistent with the } \\
\text { disposal facility closure plan and lead to disposal facility } \\
\text { closure that provides a reasonable expectation that } \\
\text { performance objectives will be met. Low-level waste } \\
\text { shall be disposed in such a manner that achieves the } \\
\text { performance objectives stated in this Chapter, consistent } \\
\text { with the disposal facility radiological performance } \\
\text { assessment. Additional requirements include: }\end{array}$ & See P. above. \\
\hline $\begin{array}{l}\text { (a) Operating procedures shall be developed and } \\
\text { implemented for low-level waste disposal facilities that } \\
\text { protect the public, workers, and the environment; ensure } \\
\text { the security of the facility; minimize subsidence during } \\
\text { and after waste emplacement; achieve long-term stability } \\
\text { and minimize the need for long-term active maintenance; } \\
\text { and meet the requirements of the closure/post-closure } \\
\text { plan. }\end{array}$ & $\begin{array}{l}\text { See P. above. } \\
\end{array}$ \\
\hline $\begin{array}{l}\text { (b) Permanent identification markers for disposal } \\
\text { excavations and monitoring wells shall be emplaced. }\end{array}$ & See P. above. \\
\hline $\begin{array}{l}\text { (c) Low-level waste placement into disposal units shall } \\
\text { minimize voids between waste containers. Voids within } \\
\text { disposal units shall be filled to the extent practical. } \\
\text { Uncontainerized bulk waste shall also be placed in a } \\
\text { manner that minimizes voids and subsidence. }\end{array}$ & See P. above. \\
\hline (d) Operations are to be conducted so that active waste & See P. above. \\
\hline
\end{tabular}


Table 4. (continued).

Facility Name: CFA-690, Radiological and Environmental Science Laboratory

Chapter IV. Low-Level Waste Requirements Facility Compliance Information

disposal operations will not have an adverse effect on any other disposal units.

(e) Operations shall include a process for tracking and

See P. above.

documenting low-level waste placement in the facility by

generator source.

(7) Alternate Requirements for Low-Level Waste

Disposal Facility Design and Operation. Requirements

other than those set forth in this Section for the design

and operation of a low-level waste disposal facility may

be approved on a specific basis if a reasonable

expectation is demonstrated that the disposal

performance objectives will be met.

Q. Closure. The following requirements are in addition to those in Chapter I of this Manual.

(1) Disposal Facility Closure Plans. A preliminary closure plan shall be developed and submitted to Headquarters for review with the performance assessment and composite analysis. The closure plan shall be updated following issuance of the disposal authorization statement to incorporate conditions specified in the disposal authorization statement. Closure plans shall:

(a) Be updated as required during the operational life of the facility.

(b) Include a description of how the disposal facility will See Q. above. be closed to achieve long-term stability and minimize the need for active maintenance following closure and to ensure compliance with the requirements of DOE 5400.5, Radiation Protection of the Public and the Environment.

(c) Include the total expected inventory of wastes to be disposed of at the facility over the operational life of the facility.

(2) Disposal Facility Closure. Closure of a disposal facility shall occur within a five-year period after it is filled to capacity, or after the facility is otherwise determined to be no longer needed.

(a) Prior to facility closure, the final inventory of the low-level waste disposed in the facility shall be prepared and incorporated in the performance assessment and composite analysis which shall be updated to support the closure of the facility.

(b) A final closure plan shall be prepared based on the final inventory of waste disposed in the facility, the plan implemented, and the updated performance assessment and composite analysis prepared in support of the facility

See P. above.

NA; this facility does not dispose of LLW.

See Q. above.

See Q. above.

See Q. above.

See Q. above.

See Q. above.

See Q. above. 
Table 4. (continued).

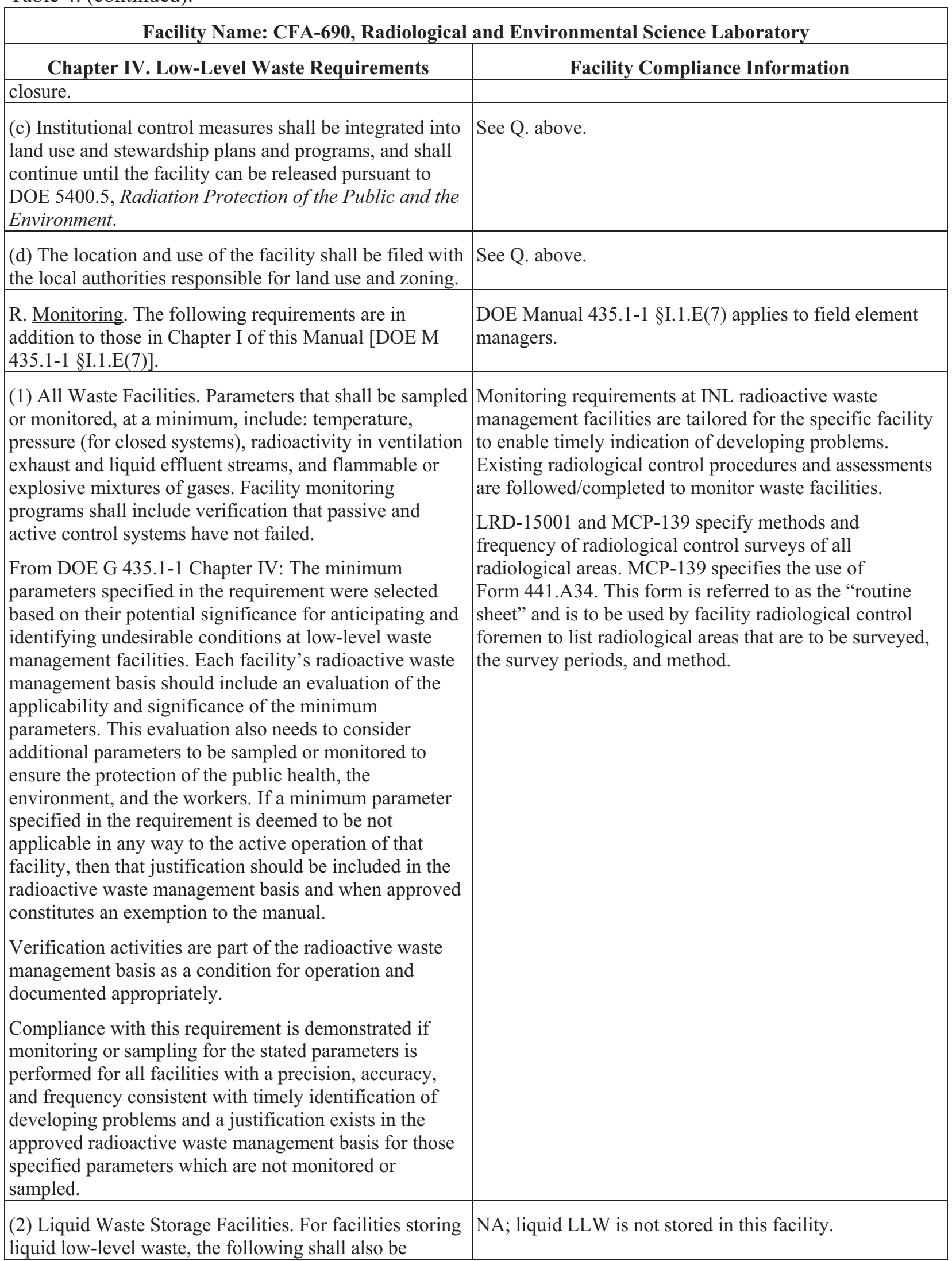


Table 4. (continued).

\begin{tabular}{|l|l|}
\hline \multicolumn{2}{|c|}{ Facility Name: CFA-690, Radiological and Environmental Science Laboratory } \\
\hline \multicolumn{1}{|c|}{ Chapter IV. Low-Level Waste Requirements } & \multicolumn{1}{|c|}{ Facility Compliance Information } \\
\hline $\begin{array}{l}\text { monitored: liquid level and/or waste volume, and } \\
\text { significant waste chemistry parameters. }\end{array}$ & \\
\hline $\begin{array}{l}\text { (3) Disposal Facilities. A preliminary monitoring plan } \\
\text { for a low-level waste disposal facility shall be prepared } \\
\text { and submitted to Headquarters for review with the } \\
\text { performance assessment and composite analysis. The } \\
\text { monitoring plan shall be updated within one year } \\
\text { following issuance of the disposal authorization } \\
\text { statement to incorporate and implement conditions } \\
\text { specified in the disposal authorization statement. }\end{array}$ & NA; this facility does not dispose of LLW. \\
\hline $\begin{array}{l}\text { (a) The site-specific performance assessment and } \\
\text { composite analysis shall be used to determine the media, } \\
\text { locations, radionuclides, and other substances to be } \\
\text { monitored. }\end{array}$ & See (3) above. \\
\hline $\begin{array}{l}\text { (b) The environmental monitoring program shall be } \\
\text { designed to include measuring and evaluating releases, } \\
\text { migration of radionuclides, disposal unit subsidence, and } \\
\text { changes in disposal facility and disposal site parameters } \\
\text { which may affect long-term performance. }\end{array}$ & See (3) above. \\
\hline $\begin{array}{l}\text { (c) The environmental monitoring programs shall be } \\
\text { capable of detecting changing trends in performance to } \\
\text { allow application of any necessary corrective action prior } \\
\text { to exceeding the performance objectives in this Chapter. }\end{array}$ & See (3) above. \\
\hline
\end{tabular}

\section{REFERENCES}

1390-08-RTC/CFA, “Routine Radioanalytical Chemistry,” Idaho National Laboratory.

1428-08-CFA, "Elemental Analysis and Analytical Chemistry at CFA," Idaho National Laboratory.

1530-09-CFA, "Solvent Extraction Batch Contacts at CFA,” Idaho National Laboratory.

1531-09-CFA, "Utility of Unusual Oxidation States of Americium for Separations at CFA," Idaho National Laboratory.

1529-09-CFA, "Silicon Carbide Temperature Monitors,” Idaho National Laboratory.

ECAR-521, "Hazard Categorization Document for the CFA-625 Laboratory," Idaho National Laboratory.

ECAR-763, "Hazard Categorization of the High Temperature Test Laboratory CFA-622," Idaho National Laboratory.

DOE, "Radiological and Environmental Sciences Laboratory Safety Analysis Document for CFA-690 and CFA-676," U.S. Department of Energy, December 2008.

DOE, RESL-AP-10, “Waste Management,” U.S. Department of Energy, October 2009.

DOE Guide 435.1-1, "Implementation Guide for Use with DOE M 435.1-1," U.S. Department of Energy, July 1999.

DOE Manual 435.1-1, “Radioactive Waste Management Manual,” U.S. Department of Energy, July 1999. 
DOE Order 435.1, “Radioactive Waste Management,” U.S. Department of Energy, July 1999.

Form 441.A34, "INL Radiological Control Required Surveys," Idaho National Laboratory

HAD-245, "Hazard Assessment Document for the Hazardous Chemical Storage Facility (CFA-637) Hazard Classification," Idaho National Laboratory.

IAG-129, "Tenant Use Agreement Between Laboratory Support Complex and CFA-637 Hazard Chemical Storage Waste Generator Services (WGS)," Idaho National Laboratory.

LI-435, "Waste Management Routine Field Activities"

LRD-15001, "Radiological Control Manual,” Idaho National Laboratory

LWP-8000, "Environmental Instructions for Facilities, Processes, Materials and Equipment," Idaho National Laboratory.

LWP-13840, "Management of Issues, Observations, and Noteworthy Practices," Idaho National Laboratory.

LWP-14002, “Timeout and Stop Work Authority,” Idaho National Laboratory

LWP-15011, "Radioactive Material Areas and Radioactive Storage Areas,” Idaho National Laboratory.

LWP-17000, "Waste Management,” Idaho National Laboratory.

MCP-139, "Radiological Surveys," Idaho National Laboratory

MCP-17000, “Waste Generator Services Waste Management," Idaho National Laboratory.

MCP-17410, "Management of Waste Storage Areas," Idaho National Laboratory.

MCP-17500, "Waste Generator Services Certification of Waste Shipments to the Nevada Test Site," Idaho National Laboratory.

PDD-17000, "Waste Management Program," Idaho National Laboratory.

PLN-114, “INL Emergency Plan/RCRA Contingency Plan,” Idaho National Laboratory.

PLN-522, "Quality Assurance Program Plan for the Waste Management/Waste Certification Program," Idaho National Laboratory.

PLN-3653, "Central Facilities Area Radioactive Waste Management Basis," Idaho National Laboratory. 